Cornell Law Library

Scholarship@Cornell Law: A Digital Repository

Cornell Law Faculty Publications

Faculty Scholarship

$11-1-1998$

\title{
The Qualitative Dimension of Fourth Amendment "Reasonableness"
}

Sherry F. Colb

Cornell Law School, sfc44@cornell.edu

Follow this and additional works at: http://scholarship.law.cornell.edu/facpub

Part of the Constitutional Law Commons, $\underline{\text { Criminal Procedure Commons, Fourteenth }}$ Amendment Commons, and the Fourth Amendment Commons

\section{Recommended Citation}

Colb, Sherry F., "The Qualitative Dimension of Fourth Amendment "Reasonableness"' (1998). Cornell Law Faculty Publications. Paper 621.

http://scholarship.law.cornell.edu/facpub/621

This Article is brought to you for free and open access by the Faculty Scholarship at Scholarship@Cornell Law: A Digital Repository. It has been accepted for inclusion in Cornell Law Faculty Publications by an authorized administrator of Scholarship@Cornell Law: A Digital Repository. For more information, please contact jmp8@cornell.edu. 


\title{
THE QUALITATIVE DIMENSION OF FOURTH AMENDMENT "REASONABLENESS"
}

\author{
Sherry F. Colb*
}

Suprene Court doctrine protects two seemingly distinct kinds of interests under the heading of privacy rights: one "substantive," the other "procedural." The Fourth Amendment guarantee against "unreasonable searches and seizures" has been generally interpreted to protect procedural privacy. Searches are typically defined as governmental inspections of activities and locations in which an individual has a reasonable expectation of privacy from observation. In the typical case, this reasonable expectation of privacy may be breached only where the government has acquired a quantitatively substantial objective basis for believing that the search would uncover evidence of a crime. Substantive privacy rights have not normally been considered in this inquiry.

This Article argues that a focus on the quantitative basis for finding probable cause is incomplete. As a corrective, Professor Colb urges a vision of the Fourth Amendment reasonableness requirement that contains both substantive and procedural safeguards. This critique of the quantitative approach to Fourth Amendment jurisprudence suggests that the Court ought to engage in substantively balancing the interests served by particular classes of searches and seizures against the costs of such government activity for the individual's sense of security and privacy, even in cases in which the government must also have probable cause and a warrant before proceeding. Such an integration of substantive and procedural privacy, one that engaged in a Fourt Amendment inquiry regarding the intrusiveness of a search or seizure, would more effectively further the privacy values embraced by the Court's criminal procedure and substantive constitutional precedents.

\section{INTRODUCTION}

Supreme Court doctrine protects two seemingly distinct kinds of interests under the heading of privacy rights: one "substantive," the other "procedural." Substantive privacy consists of the constitutionally protected liberty to engage in particular activities or to enjoy a given status without undue interference by government. Examples of substantive privacy rights include the unenumerated rights of contraception, abortion, procreation, marriage, and parental control over the education and up-

* Associate Professor, Rutgers University School of Law-Newark. The Author expresses thanks to the following individuals for reading eariy drafts of this Article and providing extremely valuable comments and suggestions: Matthew D. Adler, Michael C. Dorf, Yale Kamisar, Tracey Maclin, Henry P. Monaghan, Nancy J. Moore, Eric Neisser, Dennis M. Patterson, Elyn R. Saks, Robert A. Schapiro, George C. Thomas III, and Daniel Brian Yeager. Thanks are due as well to the tireless and professional research assistance rendered by the following students and graduates of Rutgers School of Law: Eric Blumenfeld, Beth Collier, Jack Ewing, Peter Hovde, Glenn Kurtzrock, Nicole Sonnenblick, Paul Scott, and Belle Strauss. 
bringing of children. ${ }^{1}$ When the Court recognizes a substantive privacy right as fundamental, that recognition results in a prohibition against direct governmental regulation of the protected privacy right absent narrow tailoring to a compelling interest. ${ }^{2}$ The Court has situated substantive privacy rights in the Due Process Clauses of the Fifth and Fourteenth Amendments. ${ }^{3}$

Procedural privacy is a feature of the Fourth Amendment guarantee against "unreasonable searches and seizures." 4 Under the Court's precedents, the government must ordinarily have an evidentiary foundation for subjecting people to "searches." Searches are defined as governmental inspections of activities and locations in which an individual has a reasonable expectation of privacy from observation. The government may frustrate this reasonable expectation (by performing a search) only after ac-

1. See, e.g., Planned Parenthood v. Casey, 505 U.S. 833 (1992) (abortion); Zablocki v. Redhail, 434 U.S. 374 (1978) (marriage); Roe v. Wade, 410 U.S. 113 (1973) (abortion); Eisenstadt v. Baird, 405 U.S. 438 (1972) (nonmarried couples' use of contraception); Loving v. Virginia, 388 U.S. 1 (1967) (interracial marriage); Griswold v. Connecticut, 381 U.S. 479 (1965) (married couples' use of contraception); Pierce v. Society of Sisters, 268 U.S. 510 (1925) (parental right to private education); Meyer v. Nebraska, 262 U.S. 390 (1923) (parental right to foreign language instruction). The Supreme Court has rejected the claim of a right to engage in homosexual relations, see Bowers v. Hardwick, 478 U.S. 186 (1986), but may be reconsidering its position on that question. See Romer v. Evans, 517 U.S. 620, 635 (1996) (holding that an amendment to the Colorado Constitution prohibiting all legislative, executive, or judicial action designed to protect homosexual persons from discrimination violated the Equal Protection Clause) ("We must conclude that Amendment 2 classifies homosexuals not to further a proper legislative end but to make them unequal to everyone else. This Colorado cannot do. A State cannot so deem a class of persons a stranger to its laws."); Ann Laquer Estin, When Baehr Meets Romer: Family Law 1ssues After Amendment 2, 68 U. Colo. L. Rev. 349, 366 (1997) (noting that "we might even conclude that the case [Bowers $v$. Hardwick] was overruled sub silentio in Romer").

2. See Laurence H. Tribe, American Constitutional Law $\S \S 16-7$ to $16-12$, at $1454-65$ (2d ed. 1988). The Court has, in recent years, taken to using the term "liberty interest," see Washington v. Glucksberg, 117 S. Ct. 2258, 2267 (1997); Cruzan v. Director, Missouri Dept. of Health, 497 U.S. 261, 278 (1990), or sometimes simply "liberty," see Casey, 505 U.S. at 844, where it formerly used the term "privacy." Although the use of this tern has coincided temporally with a less generous approach to substantive due process, the Court has not connected the teruminological change with the attitudinal change and has also not repudiated the conception of unenumerated rights as rights of privacy. Accordingly, and to highlight connections between substantive and procedural privacy, this Article utilizes the older terminology.

3. U.S. Const. amends. V, XIV; supra note I (citing cases relying upon the Due Process Clauses as constitutional sources of substantive privacy entitlements).

4. U.S. Const. amend. IV (stating that " $[t]$ he right of the people to be secure in their persons, houses, papers, and effects, against unreasonable searches and seizures, shall not be violated, and no Warrants shall issue, but upon probable cause, supported by Oath or affirmation, and particularly describing the place to be searched, and the persons or things to be seized").

5. In this Article, I focus primarily on searches rather than seizures. However, much of what I say regarding searches is true also of seizures. See infra notes 24-50 and accompanying text (discussing traffic stops). 
quiring a quantitatively substantial objective basis for believing that the search would uncover evidence of crime. ${ }^{6}$ Often, though not always, "probable cause" represents the quantitative standard of confidence required to authorize a search. As a rule, a magistrate performs the judicial functions of deciding in advance of a search whether the probable cause standard is met and of issuing a warrant if it is. Like the jury in a criminal trial, the police generally do not evaluate the constitutionality of criminal statutes at issue in a given case. They focus instead on whether or not they have met the quantitative burden of probable cause.

In rare cases, the Court has blurred this substantive/procedural distinction. The Court has held, for example, that a "search" of a person's internal organs, through surgery, is not necessarily permissible just because there is probable cause to believe that such a search would uncover an incriminating bullet. ${ }^{7}$ More typically (and formalistically), however, the Court consiclers the legality of a search to turn exclusively on whether there is a warrant supported by probable cause to believe that evidence of a criminal offense is present in a given location. With some notable exceptions, the Court has tended to overlook substantive matters in evaluating the reasonableness of a challenged search or seizure. ${ }^{8}$

This Article argues that there are often-overlooked affinities between substantive and procedural privacy. In particular, the Article urges a vision of the Fourth Amendment reasonableness requirement that contains both substantive and procedural safeguards. The procedural safeguards include the familiar obligation of the police to prove to a magistrate or trial judge that, prior to performing a search, they had "probable cause" or some other quantitative measure of confidence that a proposed search would disclose evidence. Such an obligation ensures that law-abiding citizens remain relatively free of governmental intrusion into their private spaces. ${ }^{9}$ The substantive part of the inquiry questions the legitimacy of the specific criminal law invoked as a basis for overriding the interest in

6. The government may, of course, conduct searches for reasons other than criminal investigation. The Clourt has generally considered such investigations as falling within a class of searches and seizures subject to the reasonableness balancing exception to the "rule" requiring probable cause and a warrant for searches and seizures. See, e.g., New Jersey v. T.L.O., 469 U.S. 325 (1985) (upholding under reasonableness balancing test searches of children at public school without probable cause or a warrant); see also infra notes 17-20 and accompanying text (examining in greater detail the "reasonableness balancing" test in contemporary Fourth Amendment doctrine).

7. See Winston $\%$ Lee, 470 U.S. 753, 766 (1985) (holding that the intrusiveness of an operation, along with the fact that the bullet that might have been recovered in surgery was not essential to the state's case, rendered the bullet removal surgery an unreasonable search under the Fourth Amendment).

8. See, e.g., Welsh v. Wisconsin, 466 U.S. 740, 759 (1984) (White, J., dissenting) (suggesting that, in his view, there is "little to commend an approach that looks to the nature of the underlying offense as an important factor to be considered in the exigentcircumstances calculus'").

9. For more about the role of law-abiding behavior or innocence in determining one's entitlement to privacy, see generally Sherry F. Colb, Innocence, Privacy, and 
remaining free from governmental observation. This entitlement to freedom from observation was most famously articulated in a Fourth Amendment case,${ }^{10}$ but it is also familiar from debates about the scope of substantively protected privacy. ${ }^{11}$ I propose in this Article that Fourth Amendment doctrine should explicitly consider the costs to privacy of various ordinary, routine intrusions, along with the relative strength of the government interests at stake in enforcing a given set of criminal statutes through a challenged investigative technique. I recommend, in other words, that Supreme Court doctrine recognize that an "unreasonable" search in violation of the Fourth Amendment occurs whenever the intrusiveness of a search outweighs the gravity of the offense being investigated.

Assimilating substantive privacy concerns into Fourth Amendment jurisprudence would yield doctrinal innovation and (in my view) progress. An important feature of what I call "substantive reasonableness" addresses the potential for disproportionality between searches otherwise supported by probable cause and a warrant when the crime at issue is relatively minor. ${ }^{12}$ This critique of the current doctrine suggests that the Court ought to engage in substantively balancing the interests served by particular classes of searches and seizures against the costs of such government activity for the individual's sense of security and privacy. This approach construes Fourth Amendment "reasonableness" as having qualitative as well as quantitative content. Any governmental intrusion that rises to the level of a "search" or "seizure"13 might, on this theory, be

Targeting in Fourth Amendment Jurisprudence, 96 Colum. L. Rev. 1456 (1996) [hereinafter Colb, Innocence].

10. See Olmstead v. United States, 277 U.S. 438, 478-79 (1928) (Brandeis, J., dissenting) (defending what he conceptualizes as the individual right to be "let alone").

11. See Bowers v. Hardwick, 478 U.S. 186, 199 (1986) (Blackmun, J., dissenting) (suggesting that the right to freedom from observation in one's bedroom ougbt to decide the legality of a hone arrest for consensual sodomy).

12. For a critical proposal regarding the appropriate role of proportionality analysis in Fourth Amendment doctrine, see Christopher Slobogin, The World Without a Fourth Amendment, 39 UCLA L. Rev. 1 (1991) (developing an alternative scheme of procedures for regulating searches and seizures, in which, inter alia, greater intrusions require greater preliminary quantitative certainty); see also Akhil R. Amar, Fourth Amendment First Principles, 107 Harv. L. Rev. 757 (1994) (proposing a radical revision of Fourth Amendment law in accordance with text, history, and logic); Anthony G. Amsterdam, Perspectives on the Fourth Amendment, 58 Minn. L. Rev. 349 (1974) (exploring the costs and benefits of a sliding-scale approach to justifying greater and lesser intrusions in the law of search and seizure).

13. See Brower v. County of Inyo, 489 U.S. 593, 596-97 (1989) (holding that "Fourth Amendment seizure [of the person] . . occur[s] ... only when there is a governmental termination of freedom of movement through means intentionally applied"); Terry v. Ohio, 392 U.S. 1, 19 n.16 (1968) (approving a definition of seizure of the person as occurring "when the [police] officer, by means of physical force or show of authority, has in some way restrained the liberty of a citizen"); Terry, 392 U.S. at 16 (explaining that "whenever a police officer accosts an individual and restrains his freedom to walk away, he has 'seized' that person"). 
disproportionate and therefore unreasonable, in spite of the sufficiency of the evidence suggesting that the search or seizure would uncover illegality.

Additionally, substantive Fourth Amendment reasonableness might place special limits on searches and seizures that interfere with the enjoyment of substantive constitutional entitlements. The ability to exercise such entitlements freely might accordingly be understood to depend on the people's confidence that the state will not only refrain from incarcerating people for the exercise of their rights, but that the state will also refrain from observing their exercise. Consider, for example, the parent's right to raise her children as she sees fit, within some designated limits (such as prohibitions against abuse and neglect, and mandatory education and vaccination laws). Jane Doe might decide not to permit her child to watch television, because she believes that watching television is a waste of time that might be better spent in more intellectually or physically active pursuits such as reading, practicing the violin, or riding a bicycle. It may not be sufficient for Doe to know that the government will not "interfere" with her no-TV rule by imposing a fine or imprisonment or by otherwise forcing her to expose her child to eight hours of television per week. To exercise freely her right to parental autonomy, Ms. Doe might require in addition the security of knowing that the government will stay out of her home and leave unobserved her chosen parenting practices, at least absent individualized suspicion of serious harm.

In the pages that follow, I critique the Supreme Court's overall failure to integrate substantive and procedural privacy. I argue in support of such integration and set forth the broad outlines of a doctrinal method for its accomplishment. The proposal I advance is, as much as possible, faithful to privacy values otherwise embraced by the Court's constitutional jurisprudence. This Article does not undertake the development of a comprehensive program for including qualitative reasonableness assessments in Fourth Amendment law. ${ }^{14}$ Its objective is instead to demonstrate that current doctrine is inadequate, even on its own terms, and to urge that what is missing is a more thorough attention to qualitative reasonableness in reviewing the constitutionality of searches and seizures.

14. Such a comprehensive program would include decisions as to the generality or specificity of qualitative rules (i.e., whether all house searches or all car searches would be considered equivalent or whether portions of houses or cars would represent distinct levels of intrusion which would trigger distinct levels of scrutiny). Such decisions, I believe, would be made by lower courts in the first instance and uItimately by the United States Supreme Court, as has been true traditionally for the contours of constitutional doctrine. The decisions would not, in my judgment, be left to police officer discretion. See Sherry F. Colb, Freedom Fram Incarceration: Why Is This Right Different From All Other Rights?, 69 N.Y.U. L. Rev. 781, 845-46 (1994) [hereinafter Colb, Incarceration] (arguing in the context of the right to be free from incarceration that police officers should not be invested with the power to prioritize among criminal statutes, because they may devalue laws that criminalize traditionally ignored conduct such as domestic violence). 
On my approach to substantive reasonableness, the intrusiveness of a search or seizure would drive the Fourth Amendment analysis, as it does in the extraordinary case of the investigative use of surgery. The Court would first recognize that a proposed police intrusion is substantial. This recognition would trigger the substantive weighing of the gravity of the crime or crimes defined in the law being enforced, against the invasiveness of the proposed governmental intrusion. The weighing would result in a finding that the Court either should or should not apply a substantively more demanding standard (or even, in theory, an absolute prohibition) to such intrusions. The Court might conclude, for example, that to search a home, the police must be investigating (and have probable cause pertaining to) a serious offense, perhaps one involving violence or substantial property conversion. This conclusion would add a substantive, qualitative inquiry to a useful but incomplete quantitative approach. As will also become clear, adding substance is entirely consistent with retaining procedure.

Part I of this Article examines and critiques the procedural, quantitative emphasis of contemporary Fourth Amendment doctrine. To illustrate the inadequacy of the prevailing approach, it surveys and evaluates the law of traffic stops. I recommend an alternative approach, one based upon a policy of integrating substance and procedure, that would supplement existing law to protect more effectively those traveling in cars from the intimidations and intrusions of arbitrary and suspicion-based police stops. Part I next acknowledges the underlying assumption of this Article: that privacy is valuable. It considers a set of arguments that Fourth Amendment privacy is overrated, and concludes by responding to these arguments.

Part II contends that within Fourth Amendment doctrine itself, one occasionally sees signs that the Supreme Court realizes the inadequacy of focusing exclusively on quantitative and procedural matters, although the Court's doctrinal responses to this realization are themselves inadequate. Part II begins by identifying an exceptional group of cases in which the Court has explicitly engaged in a form of substantive reasonableness analysis to take account of the strength or weakness of the interests supporting an allegedly unreasonable search or seizure and has weighed these interests against the intrusiveness of challenged police activity. The Part then analyzes a second category of Fourth Amendment decisions that reveals the special importance that the Court places upon protecting the home from even ordinary, routine searches and seizures. This second group of opinions necessarily rests on the assumption that greater intrusions require greater justification. The Court's selection of the home as a special locale for privacy also evidences a link between Fourth Amendment privacy and the exercise of substantive constitutional privacy rights.

Part III turns to a number of substantive constitutional law cases that explicitly embody the connection between Fourth Amendment privacy 
from observation and the freedom to enjoy substantive due process privacy entitlements. ${ }^{15}$ The Part examines these cases, especially Griswold $v$. Connecticut and Stanley $v$. Georgia, in terms of their tacit acknowledgment of the threat that a purely quantitative Fourth Amendment doctrine poses to unenumerated privacy rights.

Part IV outlines a proposal for an improved doctrine of reasonableness scrutiny. The Part first examines a specific application of the new reasonableness in the context of a space in which people tend to crave absolute freedom from observation, even though they are not engaging in any recognized constitutionally protected activity: the inside of a public restroom stall. The Part then considers the nexus between a Fourth Amendment reasonableness doctrine that consciously integrates quantitative and qualitative privacy concerns, and a traditional and revered substantive due process privacy right-the right to parental autonomy.

\section{The Fourth Amendment Reasonableness Problem}

\section{A. Current Doctrine, Its Shortcomings, and a Proposal}

Two primary lines of cases inform the meaning of the Fourth Amendment freedom to be secure against "unreasonable searches and seizures." The first constitutes the "rule" that to perform a search or seizure, the government must satisfy the probable cause and warrant requirements. ${ }^{16}$ The second line of cases can loosely be described as the exception to the rule. The cases in this category excuse the police from both the warrant and the probable cause requirements and impose in their place a more flexible "reasonableness balancing" test. This test usually involves the Court in weighing the utility of a particular kind of search or seizure in serving some "special law enforcement interest" against the degree of intrusiveness entailed in the particular technique. ${ }^{17}$

15. Henry Monaghan has offered a similar analysis in discussing the procedural implications of First Amendment free speech rights. See generally Henry P. Monaghan, First Amendment "Due Process," 83 Harv. L. Rev. 518 (1970).

16. In some cases, only probable cause is required, because obtaining a warrant would be impracticable for any of a number of reasons. See, e.g., California v. Acevedo, 500 U.S. 565,579 (1991) (automobile exception). Nonetheless, I refer to the reasonableness exception to probable cause and a warrant to make clear that the greater doctrinal divide is between searches and seizures that require probable cause (and usually a warrant as well), on the one hand, and those that require neither, on the other.

17. See, e.g., National Treasury Employees Union v. Von Raab, 489 U.S. 656, 679 (1989) (upholding, under Fourth Amendment challenge, the reasonableness of suspicionless drug testing of employees applying for promotion to positions that either involve interdiction of illegal drugs or require employees to carry firearms); Skinner v. Railway Labor Executives' Ass'n, 489 U.S. 602, 633-34 (1989) (upholding, as a matter of Fourth Amendment reasonableness, mandatory blood, urine, and breath tests-for drugs-of railroad einployees who are involved in serious train accidents); New Jersey v. T.L.O., 469 U.S. 325, 340 (1985) (upholding school principal's search of a student's purse for cigarettes, noting that the warrant requirement is "unsuited to the school environment ... [because it] would unduly interfere with the maintenance of the swift and informal disciplinary procedures needed in the schools"). 
When a class of searches or seizures falls within the reasonableness exception, this usually means that the class is relegated to a lesser level of protection than when the warrant and probable cause rule applies. ${ }^{18}$ At this reduced level, at which there generally need not be any individualized suspicion, ${ }^{19}$ the Court tends to take a deferential approach to judging the efficacy of the challenged practice in pursuing the "special" interest entailed, an approach that typically downplays the intrusiveness of the investigative technique. ${ }^{20}$

In addition to the rule that requires probable cause and a warrant and the reasonableness balancing exception to that rule, there is a third approach that the Court has sometimes taken to defining Fourth Amendment reasonableness. Very rarely, the Supreme Court has held that although probable cause and a warrant are necessary, they are not by themselves sufficient to justify a particular search or seizure. The Court announced such a principle, for example, in connection with police use of deadly force against a suspect (a Fourth Amendment "seizure") ${ }^{21}$ and

18. "As the Court's current efforts illustrate, reasonableness is a slippery concept that, without definitional restraints, can allow the range of acceptable government intrusions to expand and overwhelm the privacy interests at stake." Scott E. Sundby, A Return to Fourth Amendment Basics: Undoing the Mischief of Camara and Terry, 72 Minn. L. Rev. 383, 384-85 (1988) [hereinafter Sundby, Undoing the Mischief].

19. See, e.g., Von Raab, 489 U.S. at 665; Skinner, 489 U.S. at 634 (holding that "it is reasonable to conduct such tests [random drug testing of railroad workers after a serious accident] in the absence of ... reasonable suspicion that any particular employee may be impaired"); United States v. Martinez-Fuerte, 428 U.S. 543, 566-67 (1976) (upholding interrogative stop at permanent border checkpoint to ascertain a motorist's residence status); Camara v. Municipal Court, 387 U.S. 523, 534 (1967) (upholding routine annual inspections by city housing department). In Camara, the Court took the unusual step of requiring a warrant based upon a non-individualized form of probable cause. Such a warrant would authorize inspections on the basis of conditions in an entire area rather than conditions in an individual residence or even a particular building. See id. at 538. Scott Sundby faults the duo of Camara and Terry $v$. Ohio for the expansive apphication of the current Fourth Amendment reasonableness balancing test and for the Court's consistent tendency to uphold without inuch analysis invasions of privacy that are scrutinized under this test. See Sundby, Undoing the Mischief, supra note 18, at 385.

20. See Maryland v. Buie, 494 U.S. 325, 337 (1990) (holding that the Fourth Amendment permits a limited protective sweep incident to any home arrest and broad protective sweeps when an arresting officer has a reasonable belief that the area to be swept harbors individuals posing a danger to those on the arrest scene); O'Connor v. Ortega, 480 U.S. 709, 725 (1987) (noting that the need for efficient and proper operation of the workplace outweighs a pubhic employee's privacy interest in his office, and explaining that "[a]s with the building inspections in Camara, the employer intrusions at issue here 'involve a relatively limited invasion' of employee privacy") (quoting Camara, 387 U.S. at 537); Griffin v. Wisconsm, 483 U.S. 868, 878 (1987) (explaining that the need to preserve the deterrent effect of the supervisory arrangement of probation outweighs the probationer's privacy interest in avoiding random searches of his house); Cardwell v. Lewis, 417 U.S. 583, 591-92 (1974) (plurality opmion) (holding that warrantless examination of automobile's tires and taking of paint scrapings were de minimis invasions of constitutional interests and were therefore justified).

21. See Tennessee v. Garner, 471 U.S. 1, 9-12 (1985). 
the surgical probing for evidence (a Fourth Amendment "search").22 Such cases are unusual because of the degree of violence involved in the search or seizure. The Court has declined invitations to extend their rationales to the more common intrusions addressed by the Fourth Amendment. ${ }^{23}$ These conventional invasions include searches of houses for evidence, arrests of individuals for the commission of crimes, and stops of vehicles for highway traffic violations. Thus, when Justice Scalia recently had occasion to remark upon traffic stops, he observed that, in general, if an officer has probable cause, there is an almost irrebuttable presumption that his actions in stopping a vehicle are ipso facto reasonable. ${ }^{24}$ Fourth Amendment doctrine rarely requires a court to look for anything beyond the quantitative sufficiency of pre-stop evidence of a traffic infraction in assessing the "reasonableness" of a traffic stop.

One case exemplifying the Court's formalistic, purely quantitative approach to the Fourth Amendment, Whren v. United States, involved a traffic stop based upon probable cause. ${ }^{25}$ In Whren, the police became suspicious of a driver they observed. ${ }^{26}$ Initially, the police lacked an articulable basis for their suspicion and were therefore precluded from stopping the driver. The officers subsequently followed their suspect, waiting for him to act in a manner that would justify a stop. ${ }^{27}$ Ultimately, the suspect macle a turn without signaling and accelerated "unreasonably." 28 The police could now legally stop him on the basis of the probable cause they had to believe that he had committed a traffic violation. Once the stop had occurred, the police were constitutionally able to look inside the suspect's car and discover that Whren had committed a drug offense. Prosecution and conviction followed, and eventually the case came before the United States Supreme Court. ${ }^{29}$

The police arguably did nothing wrong in deciding to follow a vehicle that had arcused their suspicions. ${ }^{30}$ When an officer feels an inarticulable suspicion, we would not necessarily want to require that she ig-

22. See Winston v. Lee, 470 U.S. 753,767 (1985).

23. See, e.g., Zurcher v. Stanford Daily, 436 U.S. 547, 553-54 (1978) (upholding a search of a third-party newspaper upon probable cause and a warrant, without requiring a heightened showing of need).

24. See Whren v. United States, 517 U.S. 806, 817-18 (1996) (asserting that " $[w]$ ith rare exceptions not applicable here,... the result of that balancing is not in doubt where the search or seizure is based upon probable cause" and that "[w] here probable cause has existed, the only cases in which we have found it necessary actually to perform the 'balancing' analysis involved searches or seizures conducted in an extraordinary manner").

25. 517 U.S. 806 (1996).

26. 1d. at 808 .

27. See id.

28. See id.

29. See id.

30. Merely follcwing a suspect does not, for example, constitute a seizure for Fourth Amendment purposes. See, e.g., Michigan v. Chesternut, 486 U.S. 567, 574-75 (1988) (holding that police officers following a fleeing suspect in their patrol car have not "seized" the suspect). 
nore the suspicion and go on her way. What distinguishes the officers' conduct in Whren from the hypothetical conduct of a prudent police officer, however, is that the officers in Whren did not wait for something to confirm or dispel suspicions of a serious offense. Instead, the Whren officers were waiting for the targeted driver to commit a traffic violation.

The officers' wait promised to be a fruitful one. 'Vehicle stops for traffic violations occur countless times each day . . ."31 Given the vast number of traffic laws, it may now be the case that "we all violate traffic laws almost every time we enter the car." 32 As one author has observed, "[p]olice officers in some jurisdictions have a rule of thumb: The average driver cannot go three blocks without violating some traffic regulation."33 It follows from this state of affairs that any officer who is suspicious about an individual driving a car but who lacks an articulable basis for the suspicion may legally "wait for [the suspect] to violate one of a litany of traffic laws that govern the roads," 34 and when, for example, "[o] ur suspect forgets to sigual a left turn, [the officer] gains probable cause to make the traffic stop."35

The ease with which the police may stop any driver on whom they set their sights is especially troubling in view of the fact that, as the Court has acknowledged, "[a]utomobile travel is a basic, pervasive, and often necessary mode of transportation to and from one's home, workplace, and leisure activities," "[m]any people spend more hours each day traveling in cars than walking on the streets," and "[u]ndoubtedly, many find a greater sense of security and privacy in traveling in an automobile than they do in exposing themselves by pedestrian or other modes of travel."36 Once an individual is stopped, moreover, much more serious intrusions become permissible largely on the basis of safety risks inherent in the stop situation, risks which therefore do not vary depending on the seriousness

31. New York v. Class, 475 U.S. 106, 113 (1986) (quoting Delaware v. Prouse, 440 U.S. 648,659 (1979)).

32. Janet Koven Levit, Pretextual Traffic Stops: United States $v$. Whren and the Death of Terry v. Ohio, 28 Loy. U. Chi. L.J. 145, 168 (1996).

33. David A. Harris, Essay, "Driving While Black" and All Other Traffic Offenses: The Supreme Court and Pretextual Traffic Stops, 87 J. Crim. L. \& Criminology 544, 558 (1997). Harris concludes that "[a]ny time we use our cars, we can be stopped by the police virtually at their whim because full compliance with traffic laws is impossible." Id. at 582.

34. Levit, supra note 32 , at 145 .

35. Id.

36. Delaware v. Prouse, 440 U.S. 648, 662 (1979). David Harris cogently describes the role of the car in modern American life:

Simply put, it is difficult to imagine a more American activity than driving a car.

We use our cars for everything: work ... . play, and myriad other activities that make up everyday life .... In short, there are few activities more important to American life than driving.

Harris, supra note 33 , at 557 . 
of the reasonably suspected offense. ${ }^{37}$ As Justice Kennedy put it in a later, dissenting opinion,

[t]he practical effect of our holding in Whren, of course, is to allow the police to stop vehicles in almost countless circumstances. When Whren is coupled with [Maryland $v$. Wilson, which permits the police to order passengers in a stopped vehicle to exit the vehicle], the Court puts tens of millions of passengers at risk of arbitrary control by the police. ${ }^{38}$

In waiting for a traffic violation that would give them broad authority to detain their suspect and to curtail his privacy, the officers in Whren were concededly uninterested in prosecuting or apprehending anyone in connection with a routine traffic offense. The officers' goal instead was to obtain a legal basis for a stop that they had already planned to carry out, a stop for which they initially lacked the requisite level of suspicion. ${ }^{39}$

37. Such measures might include, for example, a search incident to arrest. See Chimel v. California, 395 U.S. 752, 763 (1969) (permitting and defining a search incident to arrest as "a search of the arrestee's person and the area 'within his immediate control" "). The Court has indicated that when the driver of a vehicle has been or will be arrested, the scope of a permissible search incident to arrest automatically extends to "articles inside the relatively narrow compass of the passenger compartment of an automobile," since such articles "are in fact generally, even if not inevitably, within "the area into which an arrestee might reach in order to grab a weapon." Michigan v. Long, 463 U.S. 1032, 1049 (1983) (quoting Chimel, 395 U.S. at 763). The scope of the permissible passenger-compartment search itself includes an examination of "the contents of any open or closed container found within the passenger compartment, 'for if the passenger compartment is within the reach of the arrestee, so will containers in it be within his reach.'" Id. (quoting New York v. Belton, 453 U.S. 454, 460 (1981)).

If an officer has reasonable suspicion for a stop, based on something less substantial than probable cause, perhaps an anonymous informant's tip, the officer may perform a weapons frisk upon a reasonable suspicion that the suspect is armed and dangerous, because "the policeman making a reasonable investigatory stop should not be denied the opportunity to protect himself from attack by a hostile suspect." Adams v. Williams, 407 U.S. 143, 146 (1972). The Court has "expressly recognized that suspects may injure police officers and others by virtue of their access to weapons, even though they may not themselves be armed." Michigan, 463 U.S. at 1048 (1983). Although an officer theoretically needs an articulable suspicion of danger to justify a weapons frisk, the Court has expressed the view that "the possibility of a violent encounter stems not from the ordinary reaction of a motorist stopped for a speeding violation, but from the fact that evidence of a more serious crime might be uncovered during the stop." Maryland v. Wilson, 117 S. Ct. 882, 886 (1997). This possibility of uncovering a more serious offense, of course, is-almost by definition - supported by neither probable cause nor a reasonable suspicion that would have independently justified a stop. On a similar rationale, the police may order a driver and/or the passengers in a lawfully stopped vehicle to exit the car. See Wilson, 117 S. Ct. at 886 (passengers); Pennsylvania v. Mimms, 434 U.S. 106, 111 n.6 (1977) (per curiam) (driver). The Court explained with respect to the presumptively innocent passengers of a stopped vehicle that "the motivation of a passenger to employ violence to prevent appreherision of such a [hypothetical, more serious] crime is every bit as great as that of the driver." Id.

38. Wilson, $117 \mathrm{~S}$. Ct. at 890 (Kennedy, J., dissenting).

39. See Whren v. United States, 517 U.S. 806, 808 (noting that after the police had followed the suspect for a while without developing an articulable basis for suspicion, "the Pathfinder turned suddenly to its right, without signalling, and sped off at an 
The Court held in Whren that the motivation of the officers was not a relevant legal consideration. Because the officers had probable cause to believe the suspect had turned without signaling and had accelerated "unreasonably," they were objectively justified in stopping the vehicle. ${ }^{40}$ The Court reasoned that it would be impractical to inquire into what truly motivated the police in each individual case. ${ }^{41}$

Instead of an objection to the pretextual nature of the particular stop, an objection that would have relied on the officers' subjective states of mind, the petitioner in Whren offered the Supreme Court an alternative, objective rationale for invalidating the stop. Under the objective approach proposed by petitioner, the legal question would be whether a reasonable officer in the circumstances presented would have stopped the vehicle absent an ulterior motive. ${ }^{42}$ Note the distinction between this and a subjective test. Under the objective approach, regardless of how genuine the particular officer's motives, a stop would still be unreasonable if there were no objectively reasonable basis for the stop, given the circumstances, notwithstanding probable cause to believe that a traffic violation had occurred. Under the proposed approach, in other words, probable cause to believe a traffic offense had occurred might potentially provide an insufficient basis for satisfying Fourth Amendment reasonableness. ${ }^{43}$

Consider the profound implications of this proposed objective approach. There are currently no Fourth Amendment limitations upon an officer's power to stop a driver as to whom the officer has probable cause to suspect a traffic crime, however trivial. Nevertheless, police officers do not stop every driver observed committing a traffic violation. In fact, as drivers understand, the police routinely ignore many violations. This occurs largely because the underlying purpose of most traffic rules is to prohibit the sort of conduct that might endanger the safety of drivers, passengers, and pedestrians, and traffic infractions do not invariably create such danger.

'unreasonable' speed[,]" at which point "[t] he policemen followed, and in a short while overtook the Pathfinder when it stopped behind other traffic at a red light").

40. See id. at 810 (asserting that "[a]s a general matter, the decision to stop an automobile is reasonable where the police have probable cause to believe that a traffic violation has occurred").

41. I have elsewhere expressed agreement with this view. See Colb, Innocence, supra note 9 , at $1490-91$ (contending that ${ }^{\text {" }}[\mathrm{p}]$ retextual searches should . . . not be actionable under the Fourth Amendment in most cases").

42. See Whren, 517 U.S. at 810.

43. For the related contention that a full custodial arrest might be unconstitutional in the case of a minor traffic offense, see Gustafson v. Florida, 414 U.S. 260, 266-67 (1973) (Stewart, J., concurring) (asserting that while petitioner did not raise this issue to the Court, "a persuasive claim might liave been made in this case that the custodial arrest of the petitioner for a minor traffic offense violated his rights under the Fourth and Fourteenth Amendments"). 
Under conditions in which there are virtually no cars or pedestrians in the vicinity of a particular vehicle, for example, the driver of that vehicle's failure to signal a lane change or failure to come to a complete stop at an intersection is innocuous. Conversely, under heavy traffic conditions, one could avoid violating all specific rules and nonetheless drive recklessly and place people's safety in jeopardy. Such driving would, of course, violate the broad requirement that every driver exercise caution, but this requirement itself demands the exercise of judgment (of the sort called for by an. objective reasonableness inquiry) rather than a mechanical application of law to fact seemingly called for in the case of simple violations. The police are therefore fully qualified and experienced in distinguishing between technical infractions and dangerous driving.

Under petitioner's suggested objective analysis in Whren, we would thus conclude that the reasonable police officer would not stop a driver who violated a rule under the first (formal rule violation) set of conditions (though he might pursue alternative avenues of enforcement), ${ }^{44}$ but would stop a driver who had obeyed the precise letter of the law under the second set of conditions (unsafe driving). Though police might in current practice stop the first kind of driver (formal rule violator) on occasion, it is often apparent that the officer has an inappropriate ulterior motive for the stop. ${ }^{45}$ The Fourth Amendment reasonableness of stopping a driver would accordingly turn on the hazardousness of the driver's operation of her vehicle rather than upon the formal legal status of her specific conduct under the traffic laws. ${ }^{46}$

44. See infra note 48 and accompanying text (discussing traffic citations as an example of a less restrictive alternative to traffic stops for the nondangerous instance of a traffic violation).

45. Another possibility is that the police officer is bored and not otherwise occupied, as appeared to be the case in Delaware v. Prouse, 440 U.S. 648, 650-51 (1979) ("Characterizing the stop as 'routine,' the patrolman explained, 'I saw the car in the area and wasn't answering any complaints, so I decided to pull them off.' "). As I observe elsewhere, however, the officer's explanation for the stop in Prouse does not rule out the harm of being targeted by a police officer as the one among others who is stopped. See Colb, Innocence, supra note 9, at 1489-90.

To the extent that it is standard practice, moreover, for a particular police department to stop anyone committing a minor traffic offense, perhaps due to a low incidence of serious crimes, one version of the "objective" approach might still invalidate such stops. In such a regime, suspects could not complain that other persons would not have been stopped based on similarly trivial offenses because, by hypothesis, the police routinely would enforce the formal traffic law strictly against everyone. Such a strict enforcement policy might thus doom the petitioner's specific argument in Whren, insofar as that argument focuses upon what the police in the locale would in fact do if their motives were pure. Since subjective motivation is not, however, the primary focus of iny critique of Whren, I would reject the jurisdiction-specific approach to defining objective reasonableness and embrace a truly objective standard, under which liarmless traffic violations would not provide an adequate basis for a Terry stop of a vehicle, regardless of how common or well-motivated such stops inight be.

46. The District of Columbia-the jurisdiction in which the Whren stop took placeitself had police regulations which "prohibited officers in plain clothes and officers in 
The reader might wonder at this point whether the proposed objective test for Fourth Amendment reasonableness would effectively eviscerate the traffic laws (which, after all, mediate driver and pedestrian expectations and thereby contribute globally to traffic safety). The response to this valid concern is twofold. First, the reason people obey the traffic laws (to the extent that they do) is probably not primarily the fear of being stopped by police. Since the police usually do not stop people for ordinary traffic violations, most people (excluding those who are consistently stopped pretextually ${ }^{47}$ ) do not expect to be stopped for such violations as low-level speeding, or yielding rather than stopping at an intersection. The outside possibility of a stop, at least when police are not in view, therefore may not presently work as a very strong deterrent to traffic violations.

The second answer to the worry about nullifying the traffic laws is that there are ways of penalizing drivers without pulling them over and creating a confrontation that gives rise to so many safety risks. ${ }^{48}$ An officer could, for example, record the license number of a violator and issue a citation to the owner of the vehicle. The government could thereby achieve deterrence (and some measure of retribution) without having to stop drivers who have not, in the specific case, created a serious hazard. Though limiting stops to situations presenting actual hazards requires factually sensitive determinations, such determinations are entirely appropriate if, as I have suggested, it is dangerous driving, rather than

unmarked vehicles from making traffic stops unless the violations posed an immediate threat to others." Harris, supra note 33, at 549 (citing D.C. Metropolitan Police Department General Order 303.1 (Traffic Enforcement) (effective April 30, 1992)). The Court could recognize a more general version of this principle in evaluating the reasonableness of a stop (by plainclothes or uniformed police) when a driver has committed a trivial or harmless traffic offense.

47. See, e.g., Sean Hecker, Race and Pretextual Traffic Stops: An Expanded Role for Civilian Review Boards, 28 Colum. Hum. Rts. L. Rev. 551, 559-60 (1997) (exaunining a study done by the Orlando Sentinel in which almost $70 \%$ of police stops were of AfricanAmerican or Hispanic drivers, minority drivers were held for, twice the length of time during stops, and of the cars that were searched, $82 \%$ were driven by minorities); Tracey Maclin, Race and the Fourth Amendment, 51 Vand. L. Rev. 333 (1998); see also Harris, supra note 33 (examining the disproportionate role of race in determining which drivers police stop for traffic offenses).

48. Cf. Maryland v. Wilson, 519 U.S. 408, 413 (1997) (noting that "[i]n 1994 alone, there were 5,762 officer assaults and 11 officers killed during traffic pursuits and stops"); United States v. Robinson, 414 U.S. 218, 234 n.5 (1973) (explaining, in the context of search incident to arrest, that "[ $t$ ] he danger to the police officer [who stops a car to arrest a suspect] flows froin the fact of the arrest, and its attendant proximity, stress, and uncertainty, and not from the grounds for arrest," citing a study which "concludes that approximately $30 \%$ of the shootings of police officers occur when an officer stops a person in an automobile"); Terry v. Ohio, 392 U.S. 1, 23 (1968) (suggesting that "there is the more immediate interest of the police officer in taking steps to assure himself that the person with whoun he is dealing is not armed with a weapon that could unexpectedly and fatally be used against him" since "American criminals lave a long tradition of armed violence, and every year in this country many law enforcement officers are killed in the line of duty, and thousands inore are wounded"). 
formal violation of traffic rules, that justifies stops and their associated costs. Moreover, given the plethora of traffic regulations, police must engage in such judgments already, albeit with the discretion to depart from this sort of practice on occasion to target individuals whose driving poses no dangers bur whom the police nonetheless wish to stop for some other, illegitimate reason.

As noted above, the Court does purport to assess directly the substantive reasonableness of searches and seizures in one doctrinal context, the so-called "reasonableness balancing" cases. The Court's approach to these cases, however, is not to supplement the quantitative probable cause standard with a qualitative balancing of interests, as would be the case under the proposed objective standard rejected in Whren. Instead, reasonableness balancing doctrine ordinarily operates as a mechanism that permits searches and seizures when the government lacks individualized probable cause. The Court adopts this less demanding standard when the governmert has a "special need" that justifies dispensing with individualized determinations. ${ }^{49}$ The reasonableness balancing cases accordingly provide little in the way of actual balancing ${ }^{50}$ and instead simply remove the quantitative restraints on an otherwise unlimited investigative prerogative.

\section{B. More Modest Reforms}

In response to the doctrinal reality that demands less under "reasonableness balancing" tests than under the probable cause rule, liberals ${ }^{51}$ have urged the Court to limit the number of "exceptions" to the latter and have also sought to expand the category of government practices that constitute searches and seizures triggering Fourth Amendment limits. ${ }^{52}$

49. For a critique of the "special needs" cases for their failure to provide for ex ante review of intrusions, see Slobogin, supra note 12, at 33-36.

50. This is not to condemn all of what Scott Sundby describes as initiatory intrusions" - searches that are not based upon an individualized suspicion. See Sundby, Undoing the Mischief, supra note 18. I would, however, require, as Sundby would, that such searches be greatly limited. See id. at $384-85$. I would also insist that they generally conform to the model of the health and safety inspection approved in Donovan v. Dewey, 452 U.S. 594 (1981), in which there was truly a minimal incursion on personal privacy. See infra note 310 (discussing Dewey approach to suspicionless inspections).

51. I use the term "hiberals" to refer to those who would like the Court to develop broader protection of the imdividual against government intrusions upon privacy and liberty.

52. An especially important form of investigation, which the Court has held to be outside the scope of Fourth Amendment protection, is the use of government informants to sohicit information from suspects, record conversations, and provide for electronic transmission to government officials. See United States v. White, 401 U.S. 745, 752-54 (1971) (plurality opinion) (holding that a suspect's Fourth Amendment right against unreasonable searches and seizures was not violated when, absent a warrant, government investigators overheard conversations between the suspect and a government informant who knowingly concealed a radio transmitter); Hoffa v. United States, 385 U.S. 293, 302-03 (1966) (holding that a defendant's Fourth Amendment rights were not violated 
Both of these steps might help to preserve the application of individualized suspicion requirements to government investigation. ${ }^{53}$ An expansion of Fourth Amendment coverage might also increase (or at least not reduce) the scope of the exclusionary rule as a deterrent to Fourth Amendment violations. ${ }^{54}$ Such liberal strategies, while perhaps enhanc-

when a government informant testified about the content of confidential conversations the informant had with the defendant at the government's direction, without benefit of a warrant); Lewis v. United States, 385 U.S. 206, 211-12 (1966) (holding that an undercover pohice officer did not violate the Fourth Amendment by entering the defendant's home when the defendant invited him in to purchase marijuana). These decisions have generated a great deal of controversy, because of the arguably serious intrusions on privacy they categorically exclude from constitutional scrutiny. See Tracey Maclin, Informants and the Fourth Amendment: A Reconsideration, 74 Wash. U. L.Q. 573, 634-35 (1996) (arguing that "[a] home or private conversation should not lose its constitutional protection against promiscuous pohice intrusion merely because an individual has allowed a third party's presence"); Slobogin, supra note 12, at 40, 103-04 (describing the Court's "not a search" approach to undercover operations and criticizing it on the ground that such investigations tend to be more intrusive than the typical house search and also tend to generate a sense of distrust of government and of one's friends that is destructive of citizen allegiance to the government and of democracy); see also Richard B. Parker, A Definition of Privacy, 27 Rutgers L. Rev. 275, 294 (1974) (arguing that, on a definition of privacy that protects control over who can sense us-a definition very much like the one I propose as privacy from personal knowledge- " the bugged informer usurps control over the number of people actually listening").

53. See Craig M. Bradley, Two Models of the Fourth Amendment, 83 Mich. L. Rev. 1468,1501 (1985) (arguing that "strong solutions are necessary" due to the fact that Fourth Amendment legal doctrine "is . . . full of fictitious rules and multifaceted exceptions (and exceptions to those exceptions)"); Tracey Maclin, When The Cure For The Fourth Amendment Is Worse Than The Disease, 68 S. Cal. L. Rev. 1, 37 (1994) [hereinafter Machin, Cure Worse Than Disease] (arguing that "the problem with the Court's 'special needs' cases . . . is that 'government may infringe privacy pretty much as it wishes, unconstrained by any serious judicial review") (quoting William J. Stuntz, Implicit Bargains, Government Power, and the Fourth Amendment, 44 Stan. L. Rev. 553, 555 (1992)); Carol S. Steiker, Second Thoughts About First Principles, 107 Harv. L. Rev. 820, 855-56 (1994) [heremafter Steiker, Second Thoughts] (contending that "[r] equiring warrants as the touchstone of constitutionally 'reasonable' searches responds to the lessons that history has taught about the nature of modern police forces and our legacy of racial discrimination-lessons that a regime of case-by-case determinations of 'reasonableness' seems bound to ignore"); Silas J. Wasserstrom, The Incredible Shrinking Fourth Amendment, 21 Am. Crim. L. Rev. 257, 294 (1984) [hereinafter Wasserstrom, Incredible Shrinking] (suggesting that " $[w]$ ithout the warrant requirement . . . the police could search and seize as they pleased, deterred only by the remote possibility that in a civil suit a jury would find that they not only acted unreasonably, but also im bad faith").

54. See Yale Kamisar, Comparative Reprehensibihty and the Fourth Amendment Exclusionary Rule, 86 Mich. L. Rev. 1, 10 (1987) [hereinafter Kamisar, Comparative Reprehensibility] (arguing that a proportionality approach to Fourth Amendment exclusion which would assess the relative "reprehensibility" of the pohce officer and of the crimimal in determining whether to exclude illegally obtained evidence would constitute a "pernicious modification of the exclusionary rule"); Wayne R. LaFave, The Fourth Amendment in an Imperfect World: On Drawing "Bright Lines" and "Good Faith," 43 U. Pitt. L. Rev. 307, 340 (1982) (noting that admission of "evidence supposedly obtained by the pohice in an innocent and relatively slight failure to toe the fourth amendment hine... seems to me an unvise step to take" because "in the long run a 'good faith' exception 
ing the individual's privacy and freedom to some extent, ${ }^{55}$ amount ultimately to a formalistic and accordingly inadequate device for effectively protecting privacy. ${ }^{56}$ Insisting on a minimum quantum of evidence (probable cause), without a substantive inquiry into evidence of what, ultimately leaves privacy vulnerable. ${ }^{57}$

would produce many unfortunate consequences and would do a disservice to even the deterrence objective"); Maclin, Cure Worse Than Disease, supra note 53, at 69 (quoting a State's Attorney expressing the view that " $[\mathrm{t}]$ he exclusionary rule is there to maintain the integrity of the court system"); Steiker, Second Thoughts, supra note 53, at 848 (stating that "[d] espite its many flaws, the exclusionary rule is, I am convinced, the best we can realistically do"); George C. Thomas III \& Barry S. Pollack, Balancing the Fourth Amendment Scales: The Bad-Faith "Exception" to Exclusionary Rule Limitations, 45 Hastings L.J. 21, 23 \& passim (1993) (contending that to "rebalance the [Fourth Amendment] scales, a bad-faith category of Fourth Amendment violations should be established at the other end of the spectrum from the good-faith violations," a category that would require the exclusion of evidence obtained in the course of a flagrant violation of the Fourth Amendment, even if it would normally fall within an exception to the exclusionary rule); Wasserstrom, Incredible Shrinking, supra note 53, at 395 (arguing that "[b]ecause the exclusionary rule is a remedy adopted to effectuate the fourth amendment, it makes eminently good sense to apply the rule where magistrates issue warrants without probable cause or without sufficient particularity.").

55. Robert Weisberg has suggested that conventional accounts by both liberals and conservatives have tended to exaggerate the real-world impact (both positive and negative) of the clash between the Warren Court's criminal procedure doctrine and that of the Burger Court that followed. See Robert Weisberg, Criminal Procedure Doctrine: Some Versions of the Skeptical, 76 J. Crim. L. \&c Criminology 832, 833 (1985). To the extent that "the Supreme Court doctrine has been a vastly over-rated and over-invested phenomenon," as Weisberg suggests, the substantive vacuum that las characterized this body of law might be at least partly responsible. Id. at 834 .

56. I use the 1erm "formalist" in the same way that I did in Colb, Innocence, supra note 9, at 1466-6\%. A Fourth Amendment formalist is one who focuses on procedure without elaborating a substantive vision of the ideal or intended beneficiary of the Fourth Amendment protection against unreasonable searches and seizures. As the use of the term arises in this Article, the formalist is one who defines a searcl in the absence of probable cause and a warrant as the essential Fourth Amendment violation but does not articulate the contours of a "probable cause to believe what?" that might effectively limit the degree to which the legislature may expand governinental authority to search by simply expanding the scope of the substantive criminal law. See William J. Stuntz, Substance, Process, and the Civil-Criminal Line, 7 J. Contemp. Legal Issues 1, I (1996) [hereinafter Stuntz, CivilCriminal Line] (arguing that because "[1] egislatures decide what is and is not a crime," and "courts alone decide what the law of criminal procedure looks like," the consequence is that "the government's natural incentive is to evade or exploit the procedural civilcriminal line by changing the substantive civil-criminal line" (emphasis omitted)); see also William J. Stuntz, The Uneasy Relationship Between Criminal Procedure and Criminal Justice, 107 Yale L.j. 1 (1997) [hereinafter Stuntz, Criminal Justice].

57. This is not to say, of course, that procedurally oriented strategies are not crucial to the vitality of a coninuing and developing substantive reasonableness regime. Particularly as long as police ofìicers and other government officials retain qualified immunity against liability for violating rights that are not yet clearly established, see Harlow v. Fitzgerald, 457 U.S. 800,818 (1982), the primary avenues for the litigation of novel Fourth Amendment claims of the sort that I propose will be suppression motions, appeals of suppression motions, and appeals of convictions based upon evidence admitted over suppression motions. Though folice will play an important role in applying any new standards in the 
Consider an analogy from a closely related context. Then-Justice Rehnquist suggested that it makes little sense to regulate the process by which individuals may be divested of government-granted entitlements when such entitlements may constitutionally be eliminated altogether by the legislature. ${ }^{58}$ Recent welfare reform legislation illustrates the perspicuity of Justice Rehnquist's observation. Notwithstanding the continuing vitality of the procedural due process regime of Cleveland Board of Education v. Loudermill, ${ }^{59}$ welfare legislation has successfully divested large numbers of individuals of what were previously statutory entitlements. ${ }^{60}$

field, it will be the United States Supreme Court's responsibility to imterpret and enforce the application of expanded Fourth Amendment limits. If there is to be a heightened standard with respect to bedroom searches, for example, such that only the most serious offenses would justify the intrusion, the Court would recognize this heightened standard and make the final judgments about which crimes do and do not meet the reasonableness standard. As to vehicle stops, the Court would similarly decide what sorts of factual predicates justify them (including reasonable suspicion of a violent offense, for example, but not a routine, nonthreatening traffic violation), while the police would, of necessity, retain broad discretion to determine when a specific driver has provided that factual predicate. Such heiglitened standards would contrast sharply with current quantitative doctrine in substantive content, but they would rely upon tried and true procedural mechanisms for their enforcement, including primarily the exclusionary rule championed by liberal attorneys, scholars, and jurists.

58. See Arnett v. Kennedy, 416 U.S. 134, 153-54 (1974) (plurality opinion of Rehnquist, J.) (arguing that "where the grant of a substantive right is inextricably intertwined with the limitations on the procedures which are to be employed in determining that right, a litigant in the position of appellee must take the bitter with the sweet"). Though this principle was explicitly rejected eleven years later by a majority of eight, see Cleveland Bd. of Educ. v. Loudermill, 470 U.S. 532, 540-41 (1985), its underlying insight-that procedural guarantees cannot alone provide protection for individual constitutional entitlements-continues to be true today.

59. 470 U.S. at 545-47 (loolding that when state law creates a property right, the terimination of that extant property right must be accompanied by procedures the adequacy of which rests on the U.S. Constitution rather than state legislative prerogative).

60. See Personal Responsibility And Work Opportunity Reconciliation Act of 1996, Pub. L. No. 104-193, 110 Stat. 2105, 2112-61 (1996) (amending Social Security Act, 42 U.S.C. $\S \S 601-617$ by adding $\S \S 401-419$ ). "The 1996 Act . . e eliminates aid to 300,000 children with serious disabilities and denies federal inedical and subsistence aid to legal immigrants. Food Stamp cuts of $\$ 28$ billion over six years will reduce the average food stamp benefit from 80 cents per person per meal to 66 cents, accounting for inflation." Sylvia A. Law, Ending Welfare As We Know It, 49 Stan. L. Rev. 471, 488 n.135 (1997) (book review); see also An Act Concerning Welfare Reform, Pub. Act No. 95-194, 1995 Conn. Legis. Serv. 95-194 (West) (codified as amended, Conn. Gen. Stat. § I7b). This Act terminates benefits after twenty-one months and allegedly saved Connecticut approximately $\$ 133$ million over the next two years. See Christopher Keating, Senate Passes Welfare Reform Package, Hartford Courant, May 25, 1995, at A3; see also An Act Regarding Assistance to Needy Families, Pub. Act No. 90-17, 1997 Ill. Legis. Serv. 1503 (West) (codified in $305 \mathrm{Ill}$. Comp. Stat) (replacing the federally funded AFDC program with temporary, state-funded transitional assistance that would be termimated by the State at its discretion, without any due process protections for recipients while recipients searched for jobs); 305 Ill. Comp. Stat. Ann. 5/9A-9(h) (West 1998) (prohibiting the Illmois Department of Public Aid from approving a recipient's "participation in any postsecondary education program, other than full-time, short-term vocational training for a specific job, unless the individual also is employed part-ime"); Wis. Stat. Ann. 
Similarly, purely procedural, quantitative limits on search and seizure cannot provide an effective defense against an assault on Fourth Amendment privacy interests by the legislature, a body that is usually more sympathetic to the needs of law enforcement than to the rights of suspected criminals. ${ }^{61}$ If, in order to perform a search, a police officer needs only probable cause to believe that some crime has occurred, the legislature can oblige the officer by expanding the scope of the criminal law until the point at which such probable cause (to believe that some crime has been committed) easily exists. As we saw above, this has effectively become the state of affairs in the area of traffic stops. ${ }^{62}$

The nature of contemporary Fourth Amendment protection against ordinary searches and seizures thus turns very much on substantive legislative choices. As a result, in order for the judicial branch to assert real limits on police enforcement practices, it would need to integrate a substantive element into its Fourth Amendment analysis to a much greater extent than it currently does.

The Court has chosen to stay out of the area of substance in evaluating most searches and seizures partly because of the subjectivity that seems to be an inevitable component of nonquantitative reasonableness analysis. Just as the Court has avoided expanding the category of unenumerated rights subsumed under the rubric of substantive due process, ${ }^{63}$ it prefers to leave the scope of enforceable criminal law in the

$\$ 49.19(4)(\mathrm{h})$ (Weist 1997) (requiring that aid recipients cooperate in establishing paternity or else be disqualified from eligibility for assistance so that "protective payments" for the child would be paid to a person other than the person charged with the care of the dependent child).

61. For an elegzant account of why it is rational for legislatures to undervalue the rights of criminal suspects, see Donald A. Dripps, Criminal Procedure, Footnote Four, and the Theory of Public: Choice; Or, Why Don't Legislatures Give a Damn About the Rights of the Accused?, 44 Syracuse L. Rev. 1079, 1089 (1993) (arguing that with some narrow exceptions, "legislators undervalue the rights of the accused for no more sinister, and no more tractable a cause than that a far larger number of persons, of much greater political influence, rationally adopt the perspective of a potential crime victim rather than the perspective of a suspect or defendant"); see also Illinois v. Krull, 480 U.S. 340, 365-66 (1987) (O'Connor, J., dissenting) (arguing that "[ $t]$ he legislature's objective in passing a law authorizing unreasonable searches . . . is explicitly to facilitate law enforcement" and that "[1] egislators by virtue of their political role are more often subjected to the political pressures that may tireaten Fourth Amendment values than are judicial officers"); Stuntz, Civil-Criminal Line, supra note 56, at 18 (observing that "potential criminal suspects and defendants are obvicusly not a major force with legislatures" because "the cost to legislators of overhroad liability is likely to be small[, and] [ $t$ ] he forces pushing for overbreadth seem fairly powerful").

62. See supra Part I.A.

63. See Washington v. Glucksherg, 117 S. Ct. 2258, 2267-68 (1997) (explaining, in the context of right-1o-die claims, that the Court has "always been reluctant to expand the concept of substantive due process because guideposts for responsihle decisionmaking in this unchartered area are scarce and open-ended" and has also feared that "[b]y extending constitutional protection to an asserted right or liberty interest," it would "place the matter outside the arena of public debate and legislative action" (quoting Collins v. City of Harker Heights, 503 U.S. 115, 125 (1992))); Michael H. v. Gerald D., 491 U.S. 110, 
hands of legislative majorities. ${ }^{64}$ This preference may not, on its face, seem incompatible with preserving procedural privacy as the domain of judicial review. An incompatibility results, however, not from any inherent problem in honoring majority rule, but from the unavoidable fact that substantive and procedural privacy are not two closed systems. The authority to regulate the one can be made to compensate for judicial restraints upon the authority to regulate the other, in a sort of "conservation of police power." An understanding of this dynamic relationship between substance and process helps illuminate the steps necessary to protect privacy from legislative and executive caprice.

One necessary step in implementing a substantive Fourth Amendment reasonableness doctrine would be deciding the level of generality at which such analysis would take place. As in the context of other substantive rights, such as First Amendment free speech $^{65}$ and Fourteenth Amendment equal protection, ${ }^{66}$ the Court in adopting substantive Fourth Amendment balancing would have to decide whether to perform such balancing on an ad hoc basis, deciding each case on its facts, or whether instead to make categorical judgments. The Supreme Court has already had to make this decision with respect to the current

124 (1989) (holding that there exists no substantive due process right held by a biological father with respect to a child born of his extramarital relationship with a married woman).

64. See Colb, Incarceration, supra note 14, at 783 (discussing how the courts "do not substantively scrutinize the necessity and value of a particular criminal law even though a person's hberty from incarceration hangs in the balance").

65. See, e.g., Tribe, supra note 2, \$§ 12-1 to 12-39, at 785-1061; Arnold H. Loewy, Obscenity, Pornography, and First Amendment Theory, 2 Win. \& Mary Bill Rts. J. 471 (1993) (discussing the exclusion of obscenity from First Amendment protection); John Paul Stevens, The Freedom of Speech, 102 Yale L.J. 1293 (1993) (discussing the history of freedom of speech and the varying standards of review under the First Amendment).

66. Although Equal Protection doctrine typically includes three levels of scrutiny, recent decisions have sometimes departed from a strict three-tiered analysis. See Romer v. Evans, 517 U.S. 620, 633 (1996) (applying a heightened level of rational-basis scrutiny for "“[d] iscriminations of an unusual character" to strike down a Colorado constitutional amendment barring cities from passing anti-discrimination legislation protecting gays and lesbians (quoting Louisville Gas \& Elec. Co. v. Coleman, 277 U.S. 32, 37 (1928))); Adarand Constructors, Inc. v. Pena, 515 U.S. 200, 237 (1995) (dispelling "the notion that strict scrutiny is 'strict in theory, but fatal in fact'" (quoting Fullilove v. Klutznick, 448 U.S. 448, 519 (1980))); City of Cleburne v. Cleburne Living Ctr., Inc., 473 U.S. 432, 449-50 (1985) (applying rational-basis scrutiny to strike down a city's classification of retarded adults). Justice Stevens has maintained, in fact, that in equal protection cases, the Court should (and to soine extent does) apply a level of scrutiny that is commensurate with the specific issue at bar. See Bush v. Vera, 517 U.S. 952, 1010 (1996) (Stevens, J., dissenting); City of Clebume, 473 U.S. at 452-53 (Stevens, J., concurring); Craig v. Boren, 429 U.S. 190, 212 (1976) (Stevens, J., concurring). In Bush v. Vera, Justice Stevens explained:

[O]ur equal protection jurisprudence can sometimes mislead us with its rigid characterization of suspect classes and levels of scrutiny. As I have previously noted, all equal protection jurisprudence might be described as a form of rational basis scrutiny; we apply "strict scrutiny" more to describe the likehihood of success than the character of the test to be apphed.

Bush, 517 U.S. at 1010 (Stevens, J., dissenting). 
quantitative Fourth Amendment analysis. ${ }^{67}$ The Court has required probable cause, for example, with respect to one set of intrusions, while reducing the evidentiary standard to reasonable suspicion for another. Under a substantive Fourth Amendment regime, the Court would have to decide whether to adopt a similar categorical approach in setting threshold levels of intrusiveness as well as threshold levels of government interests justifying various levels of intrusion. Alternatively, it might take an ad hoc approach, which would involve balancing particular intrusions against the government's interest in enforcing the law at issue in a specific case. The choice between. these two approaches (or something in between) mirrors the familiar choice between rules and standards. ${ }^{68}$

This Article is agnostic on the rules/standards question. The main problem with current Supreme Court doctrine in the Fourth Amendment area is its almost complete failure to engage in any substantive scrutiny at all, the consequences of which are evident in such areas as the traffic stop, which we have examined in some detail. A move in the direction of greater substantive analysis, in my view, would therefore constitute an essential and substantial improvement in the doctrine, whether the Court ultirnately chose to embrace a case-by-case or a categorical approach.

One might, of course, object to the enterprise of integrating substance and process to reinvigorate the right of privacy on the distinct ground that privacy does not constitute a worthwhile objective. William Stuntz has made this objection and proposed that our case law ought to (and to some extent already does) substitute for privacy a set of goals more appropriate to modern concerns regarding police misconduct. ${ }^{69}$

67. See Slobogin, supra note 12 , at $68-75$ (criticizing the current categorical approach and defending the quantitative sliding scale against Anthony Amsterdam's critique); cf. Amsterdam, Perspectives on the Fourth Amendment, supra note 12.

68. See, e.g., Fathleen M. Sullivan, The Justices of Rules and Standards, 106 Harv. L. Rev. 22, 56-69 (1992) (contrasting "rules," rigid, justiciable directives that set bright lines for the decisionmaker, and "standards," more general statements of policy that give the decisionmaker greater discretion to consider all relevant factors); see also Pierre Schlag, Rules and Standards, 33 UCLA L. Rev. 379 (1985) (describing the rules/standards debate from a skeptical perspective); Cass R. Sunstein, Problems with Rules, 83 Cal. L. Rev. 953, 953 \& passim (1995) (proposing that the choice of whether to employ rules or standards ought to turn on a contextual inquiry into the aggregate likelihood of errors and abuses under each alternitive approach). In support of standards over rules in the Fourth Amendment context, Slobogin suggests that clear rules are an illusion and that "even seemingly 'bright-line' rules usually become blurred as the police and the adversarial process test their outer limits." Slobogin, supra note 12, at 71 (citation omitted).

69. See, e.g., William J. Stuntz, Privacy's Problem and the Law of Criminal Procedure, 93 Mich. L. Rev. 1016, 1048 (1995) [hereinafter Stuntz, Privacy's Problem] (claiming that "[i]f we could start over, perhaps privacy would not receive constitutional protection anywhere" (emphasis omitted)); id. at 1060 (contending that although "[ $t$ ] he substantive consequences of privacy protection may have been acceptable in Boyd's era . . . . they are not acceptable now" and that "[p]erhaps it is time to reconsider the protection"); id. at 1068 (observing that " $[t]$ here are signs that this state of affairs is changing, that police coercion is displacing privacy as a focus of attention in the law of criminal investigation" 
The main focus of this Article is on the means of protecting privacy, assuming that it should be protected. The challenge to privacy, however, raises an important issue, and addressing it briefly will sharpen our sense of both why privacy matters and how best to interpret and effectuate privacy rights. The following subpart therefore takes up the challenge posed to Fourth Amendment privacy.

\section{Does Privacy Matter?}

Consider Stuntz's claims that the importance of privacy has diminished in modern society and that this diminution is most conspicuous outside of the criminal law context. In the civil arena, for example, we tend to accept as lawful the government's demands for private or business disclosures through self-reporting requirements and the subpoena power. ${ }^{70}$ Because Fourth Amendment privacy fails to occupy an important place outside the criminal law, the argument goes, it accordingly ought to be less of a concern within the criminal justice setting as well. ${ }^{7}$ The Fourth Amendment law might instead focus upon physical confrontations between private persons and the police and upon other kinds of circumstances under which the potential for police violence is great. ${ }^{72}$ On such an approach, it is only the violence of police-citizen encounters

and indicating that " $[t]$ his change is a good thing; it should proceed"). But see Daniel Yeager, Does Privacy Really Have a Problem in the Law of Criminal Procedure?, 49 Rutgers L. Rev. 1283, 1284 (1997) (responding to Stuntz that "privacy retains a significant position in the law of criminal procedure").

70. See, e.g., United States v. Miller, 425 U.S. 435, 444-45 (1976) (holding that a government's request that a bank turn over copies of an individual's deposit slips and checks does not constitute a Fourth Amendment search); Garner v. United States, 424 U.S. 648, 660-62 (1976) (holding that the requirement of completing and filing income tax returns-even as applied to those earning money illegally-does not compel an individual to incriminate herself in violation of the Fifth Amendment); California v. Byers, 402 U.S. 424, 433-34 (1971) (plurality opinion) (holding that a statute requiring motorists involved in an automobile accident to stop and identify themselves does not violate the Fifth Amendment privilege against compelled self-incriminating testimony); id. at 427-28 (explaining the centrality of self-reporting within our society and observing that "[a]n organized society imposes many burdens on its constituents"; "commands the filing of tax returns for income"; "requires producers and distributors of consumer goods to file informational reports on the manufacturing process and the content of products, on the wages, hours, and working conditions of employees"; and requires "[ $t]$ hose who borrow money on the public market or issue securities for sale to the public [to] file various information reports[; likewise,] industries must report periodically the volume and content of pollutants discharged into our waters and atnosphere"); Shapiro v. United States, 335 U.S. 1, 32-33 (1948) (upholding against Fifth Amendment challenge a subpoena requiring a wholesaler to turn over various business records that he kept pursuant to government regulations, notwithstanding the fact that those records were to be used against the wholesaler in a criminal prosecution).

71. See Stuntz, Privacy's Problem, supra note 69, at 1043.

72. See id. (criticizing the Supreme Court for "penaliz[ing] an officer for turning over a stereo turntable to look at a serial number without sufficient cause, but . . . ignor[ing] unprovoked police violence during the course of an otherwise legal search of a private home" (citations omitted)). 
and the fear that people consequently experience that furnish a persuasive rationale for a Fourth Amendment regime that selectively regulates criminal law enforcement encounters. The violence factor could thus be said to elucidate the otherwise elusive doctrinal distinction between the meaning of the Fourth Amendment in the criminal and civil contexts, respectively. ${ }^{73}$

The critique of privacy encompasses substance as well. If privacy were truly as significant as doctrinal rhetoric suggests, its protection would necessarily extend to circumscribing the content of the law as well.74 Such an extension of privacy, however, would have substantive implications that would contradict most modern constitutional law and its narrow interpretation of substantive due process, following the overruling of Lochner. ${ }^{75}$ A robust Fourth Amendment privacy jurisprudence is, on this hypothesis, an anachronism-the consequence of an approach favored during the Lociner era that reflected a mistakenly expansive vision of property and privacy rights. ${ }^{76}$ The early twentieth century was a time of greater constitutional restraints on the government, both substantive (regarding private conduct that could be circumscribed) ${ }^{77}$ and procedural

73. See id. at $1060-68$.

74. See id. at $1047-48$.

75. See G. Sidney Buchanan, A Very Rational Court, 30 Hous. L. Rev. 1509, 1521 (1993) (observing that "since 1937 no governmental regulation of economic rights has been invalidated on substantive due process grounds"); Stephen Gardbaum, New Deal Constitutionalism and the Unshackling of the States, 64 U. Chi. L. Rev. 483, 503 (1997) (arguing that the "complete and definitive rejection of substantive due process [following the Supreme Court's decision in Olsen v. Nebraska] lasted until 1965 when, in Griswold v. Connecticut, the Court revived and reaffirmed that part of the doctrine concerning personal rights and the right of privacy in particular"). Compare Lochner v. New York, 198 U.S. 45, 63-64 (1905) (striking down a New York statute prohibiting bakery employees from working more than ten hours a day or sixty hours a week, as an interference with the right of contract between employer and employee), with West Coast Hotel Co. v. Parrish, 300 U.S. 379, 392-93 (1937) (repudiating the Lochner line of cases and holding that the liberty guaranteed under the Constitution does not bar the regulation of contracts in the public interest).

76. This approach included, inter alia, an absolute bar against the seizure of an individual's property by the government. See Boyd v. United States, 116 U.S. 616, 637-38 (1886) (holding unconstitutional a subpoena requiring the production of an individual's property as evidence: against him, on the theory that "to require such an owner to produce his private books and papers, in order to prove his breach of the laws, and thus to establish the forfeiture of his property, is surely compelling him to furnish evidence against himself," and that accordingly, "[a] witness, as well as a party, is protected by the law from being compelled to give evidence that tends to criminate him, or to subject his property to forfeiture"). Stuntz suggests that "the substantive implications of Fourth and Fifth Amendment privacy protection may not have seemed as troubling a century ago as they do today." Stuntz, Privacy's Problem, supra note 69, at 1018.

77. See Lochner v. New York, 198 U.S. 45, 63-64 (1905); see also Adkins v. Children's Hosp., 261 U.S. 525, 559 (1923) (invalidating ininimum wage for women workers). 
(regarding investigative techniques that could be legally employed). ${ }^{78}$ In the modern era, by contrast, the substantive due process doctrine is quite limited, the government is free to regulate substantively in areas that were formerly off limits, ${ }^{79}$ and there is no serious judicial review of information-gathering devices such as "tax forms, OSHA inspections, routine government employment practices, and a host of other things . ..."80 The continuing vitality of the Fourth Amendment privacy ideal is thus dubious, on this analysis.

The proposal that follows from this description of Supreme Court precedent is the elimination of Fourth Amendment privacy protection, a process that may indeed already be underway. ${ }^{81}$ Going the distance would entail an explicit transposition of the Fourth Amendment protection against informational disclosure into a protection against police use of force and coercion. ${ }^{82}$ These latter are serious harms, protection against which would not have the necessary (and undesirable) civil implications that a consistent doctrine protecting privacy would have. Stuntz concludes his analysis by declaring that "[i]f we could start over, perhaps privacy would not receive constitutional protection anywhere." 83

If the foregoing critique of privacy is correct, then substantive and procedural privacy should be integrated only in the sense that both belong in the ash bin of history. There is reason, however, to be skeptical of this assessment. The argument against privacy set forth above rests in large part on a mischaracterization of what privacy means in ordinary life and in Supreme Court doctrine. Properly defined, privacy matters.

The basic difficulty with the argument against privacy is the selection of informational secrecy as the sort of "privacy" that the Court has protected under the Fourth Amendment. The notion of a constitutional right to keep secrets from the government has not actually driven the content or the rhetoric of Fourth Amendment doctrine. The Court, therefore, need not reconcile a suspect's expansive rights against informational disclosure in the criminal context with the absence of such rights in the civil context. ${ }^{84}$ The Court's guiding principle in interpret-

78. See Boyd, 116 U.S. at 637-38; see also Gouled v. United States, 255 U.S. 298 (1921) (invalidating search and seizure of private property evidence that did not constitute fruits or instrumentalities of crime).

79. See Ferguson v. Skrupa, 372 U.S. 726 (1963) (upholding, under due process challenge, law prohibiting the practice of debt adjustment outside the lawful practice of law); Williamson v. Lee Optical, 348 U.S. 483 (1955) (rejecting equal protection challenge to regulation of opticians from which sellers of ready-to-wear glasses are exempt).

80. Stuntz, Privacy's Problem, supra note 69, at 1019.

81. See id. at 1020.

82. See id. at 1044.

83. Id. at 1048 (emphasis omitted).

84. See Louis Michael Seidman, The Problems with Privacy's Problem, 93 Mich. L. Rev. 1079, 1086 (1995) [hereinafter Seidman, Problems with Privacy] (critiquing Stuntz's attack on Fourth Amendment privacy and arguing that " $[t]$ he simple fact is that inodern Fourth Amendment law has mostly assimilated the collapse of protection for informational privacy per se"). 
ing the Fourth Amendment has instead been one aspect of the "right to be let alone"- a concept that is distinct from a right to keep information secret from the government. This vision of privacy, articulated by Justice Brandeis in his dissent from the Court's opinion in Olmstead v. United States, ${ }^{85}$ ultimately became the prevailing approach in Katz $v$. United States. ${ }^{86}$ The privacy denoted by Justice Brandeis is a privacy from what I shall call governmental "personal knowledge" of the individual's private life.

What is "personal knowledge" and how does it differ from ordinary information? In the law of evidence, personal knowledge refers to the requirement that, to qualify as a lay witness in a proceeding, a person must have directly perceived a material event through the use of one or more of her five senses. ${ }^{87}$ Under the Fourth Amendment, the government's obligation to respect individual privacy has generally amounted to a prohibition against such direct perception of individuals' physical or mental states, activities, conversations, and other personal experiences that are manifestly hidden from observation, absent some justification that would qualify a proposed inspection as "reasonable." Governmental "personal knowledge" accordingly encompasses searches of bedrooms, bathrooms, closets, and desk drawers contained inside an individual's home. It also includes tape-recordings and electronic transmissions of an individual's telephone conversations conducted in a secluded place (such as a closed telephone booth). It extends to pat-downs of a person's body, strip searches, and body cavity searches.

Richard Parker urged a very similar definition of privacy in an article published twenty-four years ago, in response to the Supreme Court's decision in United States $v$. White. ${ }^{88}$ Parker offers the following definition of privacy as best capturing intuitions about the meaning and value of privacy: "privacy is control over when and by whom the various parts of us can be sensed by others. By 'sensed,' is meant simply seen, heard, touched, smelled, or tasted." 89 As Louis Michael Seidman has argued persuasively, "[i] $t$ is one thing to fill out a form that requests information about even the most persorial details of one's life. It is quite another to discover after the fact that soineone has been observing these personal details firsthand

85. 277 U.S. 438, 478 (1928) (Brandeis, J., dissenting) (arguing that the Fourth Amendment "conferred, as against the Government, the right to be let alone-the most comprehensive of rights and the right most valued by civilized men").

86. 389 U.S. 347, 353 (1967) (asserting that "although a closely divided Court supposed in Olmstead that surveillance without any trespass and without the seizure of any material object fell outside the ambit of the Constitution, we have since departed from the narrow view on which that decision rested").

87. See Fed. R. Evid. 602 (stating that "[a] witness may not testify to a matter unless evidence is introduced sufficient to support a finding that the witness has personal knowledge of the matter").

88. 401 U.S. 7.45 (1971); see Parker, supra note 52.

89. See Parker, supra note 52, at 281 (emphasis in original). 
with a telescope aimed at one's bedroom window." 90 Though in either case the government's objective might be to obtain information, the disclosure -of the sought-after information is not the principal harm suffered during searches and seizures. Indeed, as the Court has reiterated, there is no reasonable expectation of privacy at all in keeping secret the fact that one is involved in a crime (of which the government hopes to learn through its investigations). ${ }^{91}$

One might take issue with the notion of governmental "personal knowledge." The government, after all, is not a "person" who can see, hear, smell, or otherwise experience directly the hidden activities of individual private persons. This objection, however, misses the fact that the government acts through agents-specific people who do perceive events directly through their senses and who accordingly might provoke shame and distress in those private individuals who have experienced government surveillance.

The Court flagged the distinction between informational disclosures, on the one hand, and "personal knowledge" invasions of privacy, on the other, in a decision holding that random drug-testing of student athletes (through urinalysis) did not violate the Fourth Amendment. ${ }^{92}$ In reaching its conclusion, the Court explained that "the degree of intrusion [entailed in collecting a urine sample] depends upon the manner in which production of the urine sample is monitored." 93 As the majority explained:

Under the District's Policy, male students produce samples at a urinal along a wall. They remain fully clothed and are only observed from behind, if at all. Female students produce samples in an enclosed stall, with a female monitor standing outside listening only for sounds of tampering. These conditions are nearly identical to those typically encountered in public restrooms, which men, women, and especially school children use daily. Under such conditions, the privacy interests compromised by the process of obtaining the urine sample are in our view negligible. ${ }^{94}$

90. Seidman, Problems with Privacy, supra note 84, at 1090 (emphasis added).

91. See United States v. Jacobsen, 466 U.S. 109, 123 (1984) (holding that a field test of cocaine is not a search because there is no legitimate expectation of privacy in the fact of whether a white powdered substance found on a person is or is not cocaine); United States v. Place, 462 U.S. 696, 707 (1983) (holding that subjecting luggage to a sniff test by a trained narcotics detection dog was not a search because "[i]t does not expose noncontraband items that otherwise would remain hidden from public view"). Though the Court's Fourth Amendment decisions suggest the personal-knowledge privacy emphasis that $I$ describe, one might argue that even informational privacy is worthy of protection (as evidenced, perhaps, by the Fifth Amendment testimonial right against compelled self-incrimination). A complete normative response to this position, however, remains outside the scope of this Article.

92. See Vernonia Sch. Dist. 47J v. Acton, 515 U.S. 646, 664-66 (1995).

93. Id. at 658 (emphasis in original).

94. Id. 
The Court considered the respondents' claim that "the District's Policy is in fact more intrusive than this suggests, because it requires the students, if they are to avoid sanctions for a falsely positive test, to identify in advance prescription medications they are taking." ${ }^{95}$ Noting that in an earlier decision, "we held that it [advance disclosure of medications] was not 'a significant invasion of privacy,' "96 the Court emphasized the potential, within the meaning of the school district's policy, for limiting disclosure of this information to medical personnel.97 Like subpoenas and other requests/demands for personal information, the Court viewed the mandatory disclosure of personal facts regarding prescribed medication as less significant than the specifics of visual (and aural) observation of personal behavior, which it chose to describe in some detail to show how minimal such observation was.

The criticue of Fourth Amendment privacy as anachronistic acknowledges emphatically that the Fourth Amendment ought to continue to restrict house searches and pat-downs (frisks). ${ }^{98}$ It supports such restrictions, however, as having more to do with a freedom from violence and coercion than with "privacy." 99 When an individual comes into direct contact with the police, in other words, there is a frightening potential for eruptions of violence and coercion, particularly if police are themselves concerned about possible violence by the suspect.

Though potential violence is unquestionably a significant Fourth Amendment concern, it does not exhaust the constitutionally problematic features of police/citizen encounters. Conversely, the elimination of this possibility of violence would not eliminate the need for Fourth Amendment regulation of on-the-street encounters and house searches. The consequence to an individual of being subjected to a police officer's physical probe of his body, for example, is a profoundly humiliating invasion of his privacy. ${ }^{100}$ Being observed while one urinates to produce a sample for a mandatory drug-test at a place of public employment similarly intrudes upon a person's Fourth Amendment privacy. ${ }^{101}$ To charac-

95. Id. at 659 (emphasis omitted).

96. Id. (quoting Skinner v. Railway Labor Executives' Ass'n, 489 U.S. 602, 626 n.7 (1989)).

97. See id. at 660 . In addition to the requested data, the urinalysis itself provided information aboul: whether the student had used drugs. Because the information was limited to drug use (and did not reveal such conditions as pregnancy, epilepsy, or diabetes), because it was given only to medical personnel, and because it did not vary according to the identity of the student (and therefore did not result in targeting), the Court did not consider this informational disclosure significant either. Id. at 658.

98. See Stuntz, Privacy's Problem, supra note 69, at 1060-68.

99. See id. at 1064-68.

100. Cf. Sol Wachtler, After The Madness: A Judge's Own Prison Memoir 28 (1997) (describing "the stunning invasion of privacy known as a "strip search" and "the experience of being stripped naked in front of strangers who then examine every crevice and orifice of your body").

101. See National Treasury Employees Union v. Von Raab, 489 U.S. 656, 680 (1989) (Scalia, J., dissenting): 
terize some of this intrusion as "violence" might achieve consistency with a rejection of Fourth Amendment "privacy." As Daniel Yeager has noted, however, we would apply the words "violence" and "coercion" to such acts only at the cost of expanding the words well beyond their ordinary connotations. ${ }^{102}$

In addition to the violent side of some searches and seizures, Stuntz's critique of privacy identifies a second, distinct harm as legitimately encompassed within Fourth Amendment restrictions, one that is difficult to define precisely. He explains that this other harm "is about preventing invasions of dignitary interests, as when a police officer publicly accosts someone and treats him as a suspect. Arrests or street stops infringe privacy in this sense because they stigmatize the individual, single him out, and deprive him of freedom." 103 Stuntz soon abandons the privacy label for this harm and states that "[t]he real harm ... arises from the indignity of being publicly singled out as a criminal suspect and the fear that flows from being targeted by uniformed, armed police officers."104 This singling-out harm is what I have described elsewhere as the "targeting harm," in the commission of which the government singles out and treats a given individual with suspicion absent adequate justification. ${ }^{105}$ The Court has itself focused implicitly upon this targeting harm in elaborating upon the meaning of "reasonableness" in the Fourth Amendment. ${ }^{106}$ It has focused as well upon the fear experienced by an individual con-

The Government asserts it can demand that employees perform 'an excretory function traditionally shielded by great privacy,' [Skinner v. Railway Labor Executives' Ass'n, 489 U.S. 602, 626 (1989),] while 'a monitor of the same sex . . . remains close at hand to listen for the normal sounds,' [Von Raab, 489 U.S. at 661 ,] and that the excretion thus produced be turned over to the Government for chemical analysis [despite the fact that] [t] he Court agrees that this constitutes a search for purposes of the Fourth Amendment-and 1 think it obvious that it is a type of search particularly destructive of privacy and offensive to personal dignity.

But see Vernonia Sch. Dist. 47J v. Action, 515 U.S. 646, 659 (1995); supra notes $90-94$ and accompanying text.

102. See Yeager, supra note 69 , at 1287 ("Stuntz is too brisk and too dependent on a sense of 'coercion' that stretches the word all out of shape.").

103. Stuntz, Privacy's Problem, supra note 69, at 1021 (emphasis added).

104. Id. at 1064 (emphasis added).

105. See Colb, Innocence, supra note 9 , at 1487. As Stuntz recognizes in his later reference, see Stuntz, Privacy's Problem, supra note 69, at 1064, what I have called the targeting harm is not a privacy harm at all but rather a harm that cuts across different kinds of governmental actions taken against individuals (including prosecution and conviction). It springs from the official's attitude toward the individual rather than from the individual's loss of privacy or other hiberty. See Colb, Innocence, supra note 9, at 1486-91.

106. See Delaware v. Prouse, 440 U.S. 648,663 (1979) (holding that in the absence of reasonable suspicion to justify a stop, an officer arbitrarily selecting a specific motorist for a traffic stop to check for license and registration violates the Fourth Amendment); see also Colb, Innocence, supra note 9, at 1487-90 (discussing Prouse and the targeting harm). 
fronting an officer under circumstances of having been singled out. ${ }^{107}$ Stuntz complains, however, that the Court has subordinated such legitimate pursuits of the Fourth Amendment to the informational privacy right announced and praised in its Fourth Amendment cases. ${ }^{108}$

Although [ disagree with some of Stuntz's conclusions, we share several important premises in approaching the proper interpretation of the Fourth Amendment. Neither of us would adopt as a core Fourth Amendment value the protection of informational privacy in the context of criminal investigations. Both of us would reject a Fourth Amendment jurisprudence that provided no protection against police violence and terror. Finally, we would both insist that the dignitary harm of being singled out for a search or seizure (i.e., targeting) be included among the injuries recogrized in Fourth Amendment doctrine. Any disagreement we have with respect to these points concerns only the efficacy with which the Court has pursued concededly appropriate objectives.

Where we fundamentally disagree is on the value that we would each place upon what I have called privacy from personal knowledge. Stuntz would not count (and does not seriously consider) this kind of privacy as part of assessing the potential harm of a given search or seizure. ${ }^{109}$ His

107. See Prouse, 440 U.S. at 657 (suggesting that the stop of a particular motorist on the highway, whether by a roving border patrol or by a police officer checking license and registration, may create "substantial anxiety").

108. Stuntz emphasizes that "the [two] interests [in informational privacy and in freedom from targeting] are neither equally important to the law nor equally well protected. On the contrary, informational privacy-privacy as nondisclosure-is and has been preeminent." Stuntz, Privacy's Problem, supra note 69, at 1021 (emphasis omitted). He supports this claim of primacy (and hence the error of the Court's ways) by arguing that "[ $t$ ] he concept [of plain view] makes sense only in terms of informational privacy. It flows out of the interest in keeping secrets, not out of the interest in being free from unreasonable police coercion or from other kinds of dignitary harms that search targets may suffer." 1d. at 1022. The allowance of plain-view seizures could be defended, however, as perfectly consistent with a personal knowledge (rather than an informational) approach to privacy. A valid plain-view seizure, by definition, requires that no unauthorized visual surveillance or physical probing was a part of acquiring the justification for seizing the object im question. See Horton v. California, 496 U.S. 128, 136-37, 142 (1990) (limiting plain-view seizures to occasions on which it is immediately apparent that an item viewed from a place where the officer is authorized to be and located in a place to which the officer has authorized access, constitutes either fruits, evidence, instrumentalities of crime, or contraband); Arizona v. Hicks, 480 U.S. 321, 326-27 (1987) (holding that "immediately apparent" means that the police must have probable cause to seize an item in "plain view"); Michigan v. Long, 463 U.S. 1032, 1050 (1983) (noting that "[i]f, while conducting a legitimate Terry search of the interior of [an] automobile, the officer should ... discover [and seize] contraband other than weapons," the Fourth Amendment exclusionary rule does not preclude the admission of this evidence); cf. Minnesota v. Dickerson, 508 U.S. 366,379 (1993) (suppressing the evidence in the particular case as falling outside the "plain feel" doctrine because "the officer determined that the item was contraband only after conducting a further search, one not authorized by Terry or by any other exception to the warrant requirement").

109. See Stuntz, Privacy's Problem, supra note 69, at 1020-21 (explaining that "[i]n legal discourse privacy encompasses, anong other things, the ability to engage in certain 
renunciation of privacy as an important constitutional value is not, moreover, confined to the procedural domain. He elsewhere directly criticizes the doctrine of substantive due process for its recognition of substantive privacy rights. ${ }^{110}$ Stuntz suggests in Privacy's Problem that substantive due process privacy is essentially similar to the Court's Lochner-era substantive due process protection for economic rights, under which the Court repeatedly invalidated legislation regulating economic transactions. ${ }^{111}$ Stuntz then relies upon judicial and academic repudiation of the Lochner jurisprudence to argue that the procedural privacy right recognized under the Fourth Amendment ought to be repudiated as well. ${ }^{112} \mathrm{He}$ thus makes a plea for consistency between substance and procedure: Just as Lochner and its privacy progeny were wrong as a matter of substance, the corresponding Fourth Amendment protection of privacy is wrong as a matter of procedure.

Stuntz may, of course, legitimately disagree with the modern substantive due process precedents, as others have before him. ${ }^{113}$ Such disagreement does not, however, follow inevitably from an opposition to Lochner.

conduct free from government regulation, freedom from being stared at or stalked or 'singled out' in public, the 'right to be let alone,' and the ability to keep certain information or aspects of one's life secret" and claiming that "[i]n the law of criminal procedure, two kinds of privacy seem to matter": the first is "privacy interests as interests in keeping information and activities secret from the government" and the second "is about preventing invasions of dignitary interests").

110. See Stuntz, Civil-Criminal Line, supra note 56 , at 37 (maintaining that " $[t]$ hese lines [that distinguish 'real' crimes froin crimes that ordinary people do not view as crimes] are no more (though no less) guided by determinate legal criteria than the line between 'privacy' interests fundamental enough to gain the due process clause's protection and interests that fail to register on the constitutional radar," and suggesting that "the very thing that is most troubling about substantive due process [is] its unanchored quality"). See generally supra notes 75-79 and accoinpanying text (discussing Stuntz's proposed link between substantive Lochner-like constitutional protection and procedural overprotection of informational secrecy).

111. See New State Ice Co. v. Liebmann, 285 U.S. 262, 278-79 (1932) (holding unconstitutional a regulation limiting the number of businesses that could manufacture ice); Adkins v. Children's Hosp., 261 U.S. 525, 559 (1923) (holding a statute fixing minimum wage for women workers an unconstitutional interference with liberty to contract and a "naked, arbitrary exercise of power"); Adams v. Tanner, 244 U.S. 590, 596-97 (1917) (holding unconstitutional an imitiative that prohibited employnent agencies from collecting fees for their services); Allgeyer v. Louisiana, 165 U.S. 578, 592-93 (1897) (holding unconstitutional on due process grounds a Louisiana statute prohibiting the obtaining of insurance on Louisiana property from any company not licensed in Louisiana).

112. See Stuntz, Privacy's Problem, supra note 69, at 1018 (suggesting that "the substantive implications of Fourth and Fifth Amendment privacy protection may not have seemed as troubling a century ago as they do today").

113. See, e.g., Robert $H$. Bork, The Tempting of America 95-100, 110-26, 257-59 (1990); John Hart Ely, The Wages of Crying Wolf: A Comment on Roe v. Wade, 82 Yale L.J. 920 (1973); Lino A. Graglia, "Constitutional Theory": The Attempted Justification for the Supreme Court's Liberal Political Program, 65 Tex. L. Rev. 789, 794-97 (1987); see also John Hart Ely, Democracy and Distrust 14-21 (1980) (criticizing the interpretation of the Due Process Clause of the Fourteenth Amendment as containing a substantive 
In arguing that Fourth Amendment procedural privacy doctrine is out of step with the substantive repudiation of Lochner, Stuntz assumes an equation between Lochner's substantive due process of nearly a century ago and privacy substantive due process of the modern era. He thus neglects the possibility that the Supreme Court's rejection of Lochner simply signals a rejection of its underlying premise that every person possesses an inherent economic liberty that flourishes through governmental nonintervention. ${ }^{114}$ The Court has not repudiated the principle that there exist unenumerated. constitutional rights of privacy that are substantive in nature. ${ }^{115}$ Protecting Fourth Amendment privacy would therefore generate no necessary tension between substance and process in constitutional doctrine. ${ }^{116}$

As the cases discussed in this section illustrate, Fourth Amendment and due process privacy do matter to the Court, and, I believe, rightly so (although I do not offer here a general defense of the substantive due

component); Robert H. Bork, Again, a Struggle for the Soul of the Court, N.Y. Times, July 8, 1992, at A19 (same).

114. See West Coast Hotel Co. v. Parrish, 300 U.S. 379, 392 (1937) (specifying that freedom of contract is qualified, rather than absolute); see also Louis Henkin, Privacy and Autonomy, 74 Colum. L. Rev. 1410, 1416 (1974) (suggesting of the demise of the Lochner jurisprudence that: "its philosophical underpinning" of individual autonomy should not be rejected and that "[w] hat could not stand was the foreign accretion to substantive due process of laissex-faire, the apotheosis as constitutional doctrine that liberty of contract was extraordinarily sacred and that economic regulation for the public welfare was not a permissible purpose of government").

115. See Griswold v. Connecticut, 381 U.S. 479, 495-99 (1965) (Goldberg, J., concurring) (imvalidating prohibition against married couples' use of contraceptives); Skinner v. Oklahoma, 316 U.S. 535, 541 (1942) (prohibiting sterilization of thief on the ground that because procreation is a fundamental right, any government entity depriving some but not others of this right violates Fourteenth Amendment equal protection unless such differentiation can be justified as narrowly tailored to serve a compelling governmental interest). Note that the Court in Griswold cited Skinner for the proposition that "the right of privacy which presses for recognition here is a legitimate one," Griswold, 381 U.S. at 485, and thereby transformed the holding in Skinner from one concerned primarily with equal protection to one that provided authority for recognizing a substantive right of privacy.

116. Indeed, several Justices illustrated their sense of tbe potential mterconnectedness between what are sometimes called "substantive due process" liberties and Fourth Amendment rights at a recent oral argument in the case of County of Sacramento v. Lewis, $118 \mathrm{~S}$. Ct. 1708 (1998), in which the issue presented was whether a high-speed police chase ending in accidental but foreseeable injury or death violated the Constitution. At the argument, "[s]everal Justices, imcluding Cbief Justice Willam $\mathrm{H}$. Rehnquist, appeared eager to subject incidents of this kind to a ... different constitutional analysis, not under the due process guarantee of the $14^{\text {th }}$ Amendment [under which it was being argued] but under the Fourth Amendment's prohibition against unreasonable seizures." Linda Greenhouse, Court Considering Whether a Police Cbase Violated Rights, N.Y. Times, Dec. 10, 1997, at A22; see also Transcript of Oral Argument, County of Sacramento v. Le'vis, No. 96-1337, 1997 WL 770156, at *5-*6, *16-*17, *21-*22, *23, *38-*41 (Dec. 9, 1997). The Court subsequently held that a police officer does not violate substantive due process in causing such a death through deliberate or reckless indifference to life in a high-speed chase. See Lewis, $118 \mathrm{~S}$. Ct. at 1711-12. 
process privacy doctrine). The lofty goals of Fourth Amendment privacy doctrine are, however, in tension with the reality of an almost purely quantitative set of standards governing the reasonableness of searches and seizures.

\section{Cases Acknowledging Qualitative "Reasonableness"}

In constructing a better Fourth Amendment doctrine, we need not abandon the existing framework, for that framework contains the kernel of an alternative. The Supreme Court has sometimes seen fit to pierce the quantitative veil of "probable cause" and require the sort of reasonableness that takes into account the gravity of the offense being investigated, the seriousness of the intrusion involved, and/or the availability of less restrictive alternatives in pursuing police objectives. Such cases are exceptional and generally involve extraordinarily intrusive investigative procedures. ${ }^{117}$ The principle that emerges from the cases considered together, however, admits of a more expansive application without a radical destabilization of existing doctrine.

\section{A. Death and Extraordinary Bodily Intrusions}

The easiest case of substantive reasonableness to come before the Court involved police use of deadly force. In Tennessee v. Gamer, ${ }^{118}$ the issue presented was whether the Fourth Amendment permits police officers to use deadly force against a suspected felon attempting to flee and evade capture. Even the question presented implicitly conceded that the "seizure" involved in killing a person is not the same as that involved in arresting a person. If the two were the same, then the "flight" component would itself be superfluous. As long as police had probable cause to justify a felony arrest, they could choose the more expedient alternative of using deadly force rather than arrest. The Court held, however, that even adding a suspected felon's flight to the usual probable cause standard (which might make deadly force the least restrictive means of successful apprehension) would insufficiently limit the use of deadly force. ${ }^{119}$ The Court concluded that only when there is probable cause to believe that a fleeing felon would cause death or substantial bodily harm if allowed to

117. See Whren v. United States, 517 U.S. 806, 818 (1996) (observing that "[w] here probable cause has existed, the only cases in which we have found it necessary actually to perform the 'balancing' analysis involved searches or seizures conducted in an extraordinary manner, unusually harmful to an individual's privacy or even physical interests").

118. 471 U.S. 1 (1985).

119. See id. at 11 (asserting that " $[t]$ he use of deadly force to prevent the escape of all felony suspects, whatever the circumstances, is constitutionally unreasonable," and that "[w] here the suspect poses no immediate threat to the officer and no threat to others, the harm resulting from failing to apprehend him does not justify the use of deadly force to do so"). 
escape does the Fourth Amendment authorize the police to use deadly force. ${ }^{120}$

Not surprisingly, the Garmer standard of reasonableness resembles the criminal law standard for justifiable homicide by private actors. ${ }^{121}$ Just as a private person may not kill a thief running off with the person's wallet, so too the police may not use deadly force to prevent the escape of a criminal suspect whose escape would not create a substantial risk of harm to the population. As Justice White explained for the Court in Gamer, "[i]t is not better that all felony suspects die than that they escape." 122 Though Tennessee argued that the authority to use deadly force facilitates the arrest process, the Court roundly rejected this argument and, in the process, demonstrated that the application of Fourth Amendment reasonableness could sometimes impose requirements beyond probable cause and could even involve substantive analysis of the criminal law being enforced.

Gamer, of course, may be distinguished from other cases. The Supreme Court, after all, has rested an entire jurisprudence of capital punishment on the premise that state killing is sui generis and that noncapital precedents sometimes provide insufficient protection when applied in the capital context. The Court has declared by way of justification that "death is different." 123 Particularly instructive is the fact that the

120. See id. at 11 (holding that "[a] police officer may not seize an unarmed, nondangerous suspect by shooting him dead[,]" although "[w]here the officer has probable cause to believe that the suspect poses a threat of serious physical harm, either to the officer or to others, it is not constitutionally unreasonable to prevent escape by using deadly force").

121. See Model Penal Code $\$ 3.04$ (1985) (stating that "the use of force upon or toward another per;on is justifiable when the actor believes that such force is immediately necessary for the purpose of protecting himself against the use of unlawful force by such other person on the present occasion," and that in order to use deadly force, the actor must beheve "that such force is necessary to protect himself [or a third party, see § 3.05] against death [or] serious bodily harm").

122. Gamer, 471 U.S. at 11.

123. Simmons v. South Carolina, 512 U.S. 154, 171, 178 (1994) (7-2 decision on the issue) (holding that at least when future dangerousness is an issue in a capital-sentencing determination, the defendant has a due process right to require that the sentencing jury be informed of his ineligibility for parole); see id. at 172 (Souter, J., concurring) (observing that "[ $t$ ]he Court has explained that the [Eighth] Amendment imposes a heightened standard 'for reliability in the determination that death is the appropriate punishment in a specific case," (quoting Woodson v. North Carolina, 428 U.S. 280, 305 (1976) (plurality opinion of Stewart, Powell, and Stevens, JJ.)), and observing that " $[t]$ hat same need for heightened reliability also mandates recognition of a capital defendant's right to require instructions on the meaning of the legal terms used to describe the sentences (or sentencing recommendations) a jury is required to consider, in making the reasoned moral choice between sentencing alternatives"); Gilmore v. Taylor, 508 U.S. 333, 342 (1993) (stating that "the Eighth Amendment requires a greater degree of accuracy and factfinding [in a capital case] than in [a] noncapital case[ ]" and that rights provided in the capital context are not necessarily generalizable to the noncapital context); Harmelin v. Michigan, 501 U.S. 957, 995 (1991) (stating that "[o]ur cases creating and clarifying the 'mdividualized capital sentencing doctrine' have repeatedly suggested that there is no 
condition from which death is different in capital cases is life imprisonment. ${ }^{124}$ Life imprisonment, though primarily a punishment implicating Eighth Amendment and due process concerns, ${ }^{125}$ also represents an almost absolute deprivation of Fourth Amendment rights. A convict serving a term of life imprisonment loses most of his privacy ${ }^{126}$ for the remainder of his days. He also suffers a significant seizure in the form of the government's deliberate and long-term deprivation of his freedom of movement. Nonetheless, in the Court's approach to the constitutional law governing punishments, life imprisonment does not compare with death.

Whatever the merits of the "death is different" argument in the Eighth Amendment context, the Court has not limited heightened or substantive reasonableness analysis under the Fourth Amendment to cases in which death is at issue. In Winston $v$. Lee, ${ }^{127}$ for example, the Court held that a "search" of a suspect's body for a bullet, through surgery, could not be justified on the basis of probable cause alone. By contrast to Gamer, however, the Lee Court did not set out a standard for determining when-if ever-a surgical "search" for evidence might be allowed. ${ }^{128}$ Because the crime in Lee was serious, ${ }^{129}$ we do know that the seriousness of an offense is not by itself a sufficient basis for the seizure, just as it was not in Gamer. ${ }^{120}$ Necessity, or what is known as "narrow tailoring" or "least restrictive alternative" analysis in the context of equal protection, free speech, and substantive due process cases, evidently be-

comparable requirement outside the capital context, because of the qualitative difference between death and all other penalties").

124. See Harmelin, 501 U.S. at 994-96 (finding that sentence of life in prison without possibility of parole for possession of 672 grams of cocaine did not constitute cruel and unusual punishment, despite defendant's status as a first-time felon); id. at 996 (indicating that "[w]e have drawn the line of required individualized sentencing at capital cases, and see no basis for extending it further").

125. See generally Colb, Incarceration, supra note 14 . s.

126. See Hudson v. Palmer, 468 U.S. 517, 527-28 (1984) (holding that a convict in prison has no legitimate Fourth Amendinent expectation of privacy in his cell).

127. 470 U.S. 753 (1985). The Court observed that "[a] compelled surgical intrusion into an individual's body for evidence ... implicates expectations of privacy and security of such magnitude that the intrusion may be 'unreasonable' even if likely to produce evidence of a crime." Id. at 759.

128. There is language in the opinion that suggests that such surgery would perhaps be "reasonable" under the Fourth Amendinent if essential to the government's case. See id. at 766 (asserting that the fact that the "Commonwealth has available such substantial evidence of the origin of the bullet restricts the need for the Commonwealth to compel respondent to undergo the contemplated surgery" (emphasis added)).

129. Id. at 755 (explaining that "the respondent Rudolph Lee [was] suspected of attempting to commit armed robbery").

130. See Tennessee v. Garner, 471 U.S. 1, 3 (1985) (holding "that such force may not be used unless it is necessary to prevent the escape and the officer has probable cause to believe that the suspect poses a significant threat of death or serious physical injury to the officer or others") (emphasis added). 
comes part of the Fourth Amendment calculus once a very serious intrusion, even one that does not involve the use of deadly force, is at issue. ${ }^{131}$

In an analogous case in the due process context, Rochin $v$. California, ${ }^{132}$ the Supreme Court held that police had violated the Constitution when they forcibly took a suspect to the hospital to have his stomach pumped after the suspect reacted to police questioning about two capsules on his nightstand by swallowing the capsules. The capsules turned out to be morphine, but the Court held that, because the officers' conduct in obtaining the morphine from the suspect "shocked the conscience," the evidence was inadmissible as a matter of due process. ${ }^{133} \mathrm{Be}-$ cause the Court decided Rochin prior to its decision to apply the Fourth Amendment exclusionary rule to the states, ${ }^{134}$ it is likely that similar facts arising today would be addressed under the Fourth Amendment "reasonableness" principle and would be resolved on the basis of some of the same principles discussed in Winston $v$. Lee (the surgery case). ${ }^{135}$

131. In the case of free speech and other rights, the required criteria for constitutionality of a direct burden on the exercise of a fundamental right include the presence of a compelling governmental interest and the lack of less restrictive alternative means of pursuing that interest. See, e.g., Simon \& Schuster, Inc. v. Members of N.Y. State Crime Victims Bd., 502 U.S. 105, 121-23 (1991) (invalidating under the First Amendment a statute requiring that income from works describing an individual's crimes be set aside in an escrow fund devoted to compensation of victims and other creditors of the selfdescribed criminal). For a critical analysis of least-restrictive-alternative law, see Colb, Incarceration, supra note 14, at 827-39.

132. 342 U.S. 165 (1952).

133. Id. at 172. The Court concluded that:

[T] he proceedings by which this conviction was obtained do more than offend some fastidious squeamishness or private sentimentalism about combatting crime too energetically. This is conduct that shocks the conscience. Illegally breaking into the privacy of the petitioner, the struggle to open his mouth and remove what was there, the forcible extraction of his stomach's contents-this course of proceeding by agents of government to obtain evidence is bound to offend even hardened sensibilities. They are methods too close to the rack and the screw to permit of constitutional differentiation.

Id.

134. See Wolf v. Colorado, 338 U.S. 25, 27-28 (1949) (declining the invitation to extend to state criminal trials the federal exclusionary rule of Weeks v. United States, 232 U.S. 383 (1914)); Mapp v. Ohio, 367 U.S. 643 (1961) (overruling Wolf and accordingly extending the application of the exclusionary rule to the states). The Court had occasion again to consider evidence under the Rochin Due Process standard in Irvine v. California, 347 U.S. 128 (1954) (refusing to require under Due Process clause the exclusion of evidence obtained through an illegal wiretap, finding that the government's conduct did not shock the conscience), and Breithaupt v. Abram, 352 U.S. 432 (1957) (holding that drawing blood from an unconscious suspect did not shock the conscience and that the Due Process Clause therefore did not require suppression of the blood evidence).

135. Winston v. Lee, 470 U.S. 753, 762 n.5 (observing that "the procedure in Sclimerber [in which blood was taken from a person suspected of driving while intoxicated] contrasted sharply with the practice im Rochin $v$. Califormia, in which police officers broke into a suspect's room, attempted to extract narcotics capsules he had put into his mouth, took him to a hospital, and directed that an emetic be adininistered to induce vomiting," 
Though these examples embrace a substantively demanding Fourth Amendment reasonableness in the search and seizure context, the Court has generally resisted extending the heightened reasonableness requirement beyond the extraordinary cases in which government officials seek to penetrate the flesh of a suspect. The Court has, however, sometimes treated the more ordinary search and seizure cases differently from one another, depending on the degree of intrusiveness involved. Such cases provide a basis in precedent for re-examining the Court's reluctance to apply heightened reasonableness analysis more broadly than it is currently applied. The first of these cases is Payton $v$. New York. ${ }^{136}$

\section{B. Slouching Toward Reasonableness}

About four years before its decision in Payton, the Supreme Court had upheld warrantless public felony arrests based upon probable cause. ${ }^{137}$ Relying on constitutional history, dicta from its own prior precedents, and prevailing state practice, the Court in United States $v$. Watsor concluded that the usual requirement that an officer obtain a warrant prior to any search or seizure should not apply in the case of a public arrest. In Payton, the Court faced the issue whether to extend the logic of the warrant exception in Watson to arrests carried out in a suspect's private home. ${ }^{138}$

An arrest warrant certifies that there is probable cause to believe that the designated arrestee has committed a criminal offense. ${ }^{139}$ A neutral magistrate issues the warrant based upon sworn evidence presented to her by the police officer(s) seeking the warrant. ${ }^{140}$ The warrant proce-

and that 'Rochin, recognizing the individual's interest in 'human dignity,' held the search and seizure unconstitutional under the Due Process Clause" (citations onnitted)).

136. 445 U.S. 573 (1980).

137. See United States v. Watson, 423 U.S. 411,421 (1976) (explaining that "[t]he balance struck by the common law in generally authorizing felony arrests on probable cause, but without a warrant, has survived substantially intact").

138. Payton, 445 U.S. at 574--75 ("In United States v. Watson, 423 U.S. 411, we upheld a warrantless 'midday public arrest,' expressly noting that the case did not pose 'the still unsettled question ... "whether and under what circumstances an officer inay enter a suspect's home to inake a warrantless arrest." " (ellipsis in original)).

139. "If it appears from the complaint, or from an affidavit or affidavits filed with the complaint, that there is probable cause to believe that an offense has been coinmitted and that the defendant has committed it, a warrant for the arrest of the defendant shall issue to any officer authorized by law to execute it." Fed. R. Crim. P. 4(a).

140. See, e.g., Johnson v. United States, 333 U.S. 10, 13-14 (1948) ("The point of the Fourth Amendment, which often is not grasped by zealous officers, is not that it denies law enforcement the support of the usual inferences which reasonable men draw from evidence. Its protection consists in requiring that those inferences be drawn by a neutral and detached magistrate instead of being judged by the officer engaged in the often competitive enterprise of ferreting out crime."); see also Coolidge v. New Hampshire, 403 U.S. 443, 450 (1971) ("[T] he whole point of the basic rule [that a warrant must be granted by a neutral and detaclied magistrate] . . . is that prosecutors and policemen simply cannot be asked to maintain the requisite neutrality with regard to their own investigations--the 'competitive enterprise' that must rightly engage their single-minded attention."); cf. 
dure is meant to ensure that the zealous police officer, engaged in the "often competitive enterprise of ferreting out crime,"141 does not arrest a person as to whom he lacks probable cause.

The Supreme Court held in Payton that a police officer who wishes to arrest an individual in her home must first obtain an arrest warrant, even though the same arrest could have taken place in public without a warrant. ${ }^{142}$ The majority explained that a home represents the primary zone of Fourth Amendment privacy. ${ }^{143}$ The Court reasoned that an arrest occurring inside a person's home is more intrusive and disruptive than one transpiring in public. This is because, in addition to the loss of liberty inherent in any arrest, a home arrest also involves a loss of privacy, consisting of police entry into the suspect's home and any accompanying search of that home necessary to locate the suspect. The Court concluded that an arrest warrant would therefore be required in the case of a private arrest. In this way, the Court attempted to ensure that a person's home would not be invaded lightly.

One might plausibly take issue with the assumption that because the home is private, a home arrest is therefore more intrusive than a public one. The very privacy from public scrutiny offered by the home might alleviate rather than aggravate the embarrassment of being taken into custody. ${ }^{144}$ Even accepting, however, the Court's estimation of the rela-

Connally v. Georgia, 429 U.S. 245, 250-51 (1977) (per curiam) (holding that a search warrant issued by a magistrate who would receive a five-dollar fee for issuing a warrant but no fee for refusing to issue a warrant violated the protections afforded the defendant under the Fourth and Fourteenth Amendments).

141. Johnson, 333 U.S. at 14; see also Arizona v. Evans, 514 U.S. 1, 15 (1995); Illinois v. Krull, 480 U.S. 340, 351 (1987).

142. Payton, 445 U.S. at 576, 588-90.

143. See id. at 585 (asserting that "[a]s the Court reiterated just a few years ago, the 'physical entry of the home is the chief evil against which the wording of the Fourth Amendment is directed'" (quoting United States v. United States Dist. Court, 407 U.S. 297, 313 (1972))); id. at 589-90 (noting that " $[\mathrm{t}]$ he Fourth Amendment protects the individual's privacy in a variety of settings" and that in no setting "is the zone of privacy more clearly defined than when bounded by the unambiguous physical dimensions of an individual's home-a zone that finds its roots in clear and specific constitutional terms: 'The right of the pe:ople to be secure in their . . . houses . . . shall not be violated.' That language unequivocally establishes the proposition that ' $[\mathrm{a}] \mathrm{t}$ the very core [of the Fourth Amendment] stands the right of a man to retreat into his own hoine and there be free from unreasonable governmental intrusion." (ellipses in original) (alterations in original) (quoting Silverman v. United States, 365 U.S. 505, 511 (1961))); id. at 598 (adding that "the absence of any 17th- or 18th-century English cases directly in point, together with the unequivocal endorsement of the tenet that 'a man's house is his castle,' strongly suggests that the prevailing practice was not to make such arrests except in hot pursuit or when authorized by a warrant"); id. at 596-97 (contending that " $[\mathrm{t}]$ he zealous and frequent repetition of the adage that 'a man's house is his castle,' made it abundantly clear that both in England and in the Colonies 'the freedom of one's house' was one of the most vital elements of English liberty").

144. See, e.g., Wachtler, supra note 100 , at 109. Judge Wachtler explains that: It is difficult to convey the intensity and infiexibility of the deliberate humiliations visited upon me on the orders of [the United States Attorney]. The very form of 
tive gravity of injuries, there are independent difficulties with the Court's resolution of the Payton issue.

First, a warrant requirement does not ensure, as the Court seems erroneously to have assumed, ${ }^{145}$ that home arrests occur only when the public alternative is not feasible. If an officer has probable cause to justify an arrest (a Fourth Amendment requirement regardless of where the arrest occurs), then he would presumably be able to obtain an arrest warrant from a magistrate and carry out the arrest in private, even if a public arrest would have been entirely feasible. Unlike in Lee (bullet surgery) and Gamer (deadly force), the Court in Payton does not require an officer to demonstrate to the magistrate that he has some reason beyond the usual showing of probable cause to perform a home arrest.

To the extent that the Court distrusted the zealous officers and chose the more neutral magistrate in Payton for that reason, the solution cannot effectively remedy the problem. A magistrate providing an arrest warrant has reviewed only the question whether there is probable cause to arrest the individual in question. Though the officer must also have probable cause to believe the suspect is indeed inside his home at the time of an arrest-probable cause to search for the suspect-the magistrate does not review the officer's judgment on this probable cause question. ${ }^{146}$ In short, the Payton arrest warrant requirement not only fails to ensure that a home arrest is necessary in a particular case, it does not even provide a neutral magistrate's confirmation that the home-entry-the element that distinguishes a home arrest from a public arrest-is based upon probable cause to believe the suspect is at home. It is the police officer alone who determines prior to the search whether there is prob-

the arrest could not have been contrived with any other purpose in mind. Why, otherwise, would I have been melodramatically surrounded on a crowded public highway, literally dragged from my car, and frisked and handcuffed for all to see? ... In my case ... there was obviously not the slightest risk in delaying the arrest until I reached a secluded neighborhood or even my home, which was five minutes away.

Id.; see also Griswold v. Connecticut, 381 U.S. 479, 509 (1965) (Black, J., dissenting) (“[A] person can be just as much, if not more, irritated, annoyed and injured by an unceremomious public arrest by a policeman as he is by a seizure in the privacy of his office or home.").

145. See Payton, 445 U.S. at 586 (explaining that the Court has "long adhered to the view that the warrant procedure minimizes the danger of needless intrusions" such as physical entry by police into the home); see also Steagald v. United States, 451 U.S. 204, 214 n.7 (1981) (observing that the arrest warrant required in Payton "'necessarily also authorizes a limited invasion of [the arrestee's] privacy interest when it is necessary to arrest him in his home"" (emphasis added) (quoting Payton)).

146. See Payton, 445 U.S. at $602-03$ (specifically noting that although "[i]t is true that an arrest warrant requirement may afford less protection than a search warrant requirement," the arrest warrant nonetheless "will suffice to interpose the magistrate's determination of probable cause between the zealous officer and the citizen," and adding that "[i]f there is sufficient evidence of a citizen's participation in a felony to persuade a judicial officer that his arrest is justified, it is constitutionally reasonable to require him to open his doors to the officers of the law"). 
able cause to enter the house. Although the Court may have had a defensible instinct that a home arrest is worse than a public arrest, the mechanism selected by the Court to address its instinct-the arrest warrant requirement-provided a blunt (if not entirely ineffectual) instrument for protecting the individual's home against unnecessary arrest-related intrusions. ${ }^{147}$

About a year after deciding Payton, the Court held in Steagald $v$. United States that when carrying out an arrest in the home of an individual other than the arrestee himself, the police must obtain a search warrant (specifying probable cause to believe that the criminal suspect who is subject to arrest is located in the home of the third party). An arrest warrant alone, in other words, is an insufficient basis for arresting a suspect in an innocent third party's home. ${ }^{148}$ This result might seem better tailored to its purposes than the holding in Payton. In Steagald, unlike in Payton, the home arrest requires an assurance from a neutral magistrate that the privacy of an innocent third party's home is not improperly invaded.

Recall that every home arrest requires that there be probable cause to believe both that the suspect committed a crime and that he may be found in the particular home in which he is sought. ${ }^{149}$ The function of an arrest warrant, required by Payton, is to ensure through a neutral magistrate that the suspect's arrest is justified, a matter that is separate from the question of where that arrest should take place. The search warrant required by Steagald, by contrast, might help increase the reliability of the determination that the suspect is indeed located in the third party's home. In this way, the warrant ensures that the intrusion upon an innocent third party's privacy is justified. Upon closer examination, however, the seeming precision of the Court's approach in Steagald turns out to be illusory.

One might expect that to justify an invasion of an innocent third party's privacy in order to carry out the arrest of a suspect, the police would have to show more than probable cause with respect to the suspect's presence in the third party's home. They might have to show, for

147. One way in which the warrant requirement might "work" here is that a police officer who can arrest in public might do so because obtaining a warrant is a nuisance. See Ronald J. Allen, et al., Constitutional Criminal Procedure 720 (3d ed. 1995) (suggesting that " $[t]$ he arrest warrant requirement-like a search warrant requirement-may deter the police from making home arrests"). This logic, however, is somewhat troubling if we believe that the warrant requirement is meant to ensure that all arrests and searclies truly meet the probable cause standard rather than to exploit police inertia to discourage legitimate searches and seizures.

148. See Steagald, 451 U.S. at 205, 213-14, 216 (holding that a law enforcement officer may not "legally search for the subject of an arrest warrant in the home of a third party without first obtaining a search warrant").

149. See Payton, 445 U.S. at 603 (indicating that "for Fourth Amendment purposes, an arrest warrant founded on probable cause [to believe that a citizen participated in a felony] implicitly carries with it the limited authority to enter a dwelling in which the suspect hives when there is reason to believe the suspect is within" (emphasis added)). 
example, that there is not a less intrusive alternative to entering the third party's home to arrest the suspect, perhaps because the suspect is hiding himself there with no immediate plans of leaving. Otherwise, the third party might legitimately ask why the police did not arrest the suspect in public or in the suspect's own home instead.

The Court could have expressly required a showing of necessity, as it implicitly did in Winston $v$. Lee with respect to the use of surgery. ${ }^{150}$ It could alternatively (or additionally) have required a showing that the offense in question was serious enough to merit this especially intrusive alternative, as it did in Tennessee $v$. Garner with respect to the use of deadly force. ${ }^{151}$ The Court did neither, however. It instead required only that a magistrate review the application of the substantive standard that also happens to govern the arrest of a suspect in his own home (which itself requires only that a magistrate confirm the application of the substantive standard that also governs a public arrest, i.e., probable cause to arrest). Finally, it is not apparent why a search warrant would be especially helpful in the context of Steagald. If the purpose of the warrant is to check police zeal in especially tempting law enforcement environments, the Court does not explain, in either Payton or Steagald, why the police would be most tempted in a third party's home. ${ }^{152}$

A third case addressing the issues surrounding home arrests and the special threat they pose to Fourth Amendment privacy is Welsh $v$. Wisconsin..$^{153}$ Welsh involved the arrest of a man who earlier had driven while intoxicated in the State of Wisconsin, a civil violation at the time. ${ }^{154}$ Upon their arrival at the scene of the violation, the police were directed by a witness to the suspect's car, where they found a registration with an address. They proceeded to the stated address, which turned out to be the suspect's home. They promptly gained entry and arrested Welsh. ${ }^{155}$

150. 470 U.S. $753,765-66$ (1985).

151. 471 U.S. 1, 11-12 (1985).

152. One might argue that police beliavior during public arrests is constrained by its visibility to "the people." The people, however, will often know nothing about whether the police have or lack probable cause against the suspect in question. Furthermore, an arrest in "public" (i.e., not in a private hoine) need not have any nonparty witnesses. Finally, an arrest in a third party's home inay provide the greatest inotivation for the police to exercise self-control, since the resident is not under suspicion (and is therefore a credible witness) and inay care enough to testify against a police officer who has treated her visitor improperly.

153. 466 U.S. 740 (1984).

154. Id. at $746 \mathrm{n} .6$ (noting that "at the time of the arrest the police were acting as if they were investigating and eventually arresting for a nonjailable traffic offense that constituted only a civil violation under the applicable state law").

155. See id. at 742-43 (indicating that Jablonic, the witness, "told one officer what he had seen" and that "[ $t]$ he officer checked the motor vehicle registration of the abandoned car and learned that it was registered to the petitioner, Edward G. Welsh," after which "the police proceeded to the petitioner's home ... gained entry into the house ... [, and] the petitioner was placed under arrest for driving or operating a motor vehicle wliile under the influence of an intoxicant"). 
In reviewing the facts of the case, the Supreme Court noted that the home arrest took place at night, that the police found Welsh undressed in his bedroorn, and that they had failed to obtain a warrant for the arrest. ${ }^{156}$ The State argued that the warrantless arrest was justified because there existed an "exigent circumstance" which excused the police from having to obtain a warrant. ${ }^{157}$ Although the Court assumed, for purposes of argument, that there was an exigent circumstance presentthe likelihood that critical evidence of intoxication while driving would be metabolized out of existence during the time necessary to obtain a warrant-the Court nonetheless held that the arrest violated the Fourth Amendment and that it therefore tainted the evidence obtained in the ensuing search incident to arrest. ${ }^{158}$ Because the arrest was performed in a person's home at night, a time when the privacy interest in the home is greatest, ${ }^{159}$ and because the offense in question was "only a minor" (civil rather than criminal) offense, the Court held that the police should not have entered without an arrest warrant. ${ }^{160}$

The Court: in Welsh did something it has usually refused to do: It took note of both the gravity of the offense in question (a "minor of-

156. See id. at 743 (noting that "[w]ithout securing any type of warrant, the police proceeded to the petitioner's home, arriving about 9 p.m." and that, "[p]roceeding upstairs to the petitioner's bedroom, they found him lying naked in bed").

157. See id. at 753 ("[T] he only potential emergency claimed by the State was the need to ascertain the petitioner's blood-alcohol level.").

158. See id. at 754 (indicating that "[e]ven assuming . . . that the underlying facts would support a finding of this exigent circumstance, mere similarity to other cases involving the imminent destruction of evidence is not sufficient," and that "a warrantless home arrest cannot be upheld simply because evidence of the petitioner's blood-alcohol level might have dissipated while the police obtained a warrant").

159. See id.; see also Gooding v. United States, 416 U.S. 430, 462 (1974) (Marshall, J., dissenting) (contending that "[i]n my view, there is no expectation of privacy more reasonable and more demanding of constitutional protection than our right to expect that we will be let alone in the privacy of our homes during the night"); Coolidge v. New Hampshire, 403 U.S. 443, 477 (1971) (recognizing that a midnight entry into a home is an "extremely serious intrusion"); Jones v. United States, 357 U.S. 493, 498 (1958) (claiming "it is difficult to imagine a more severe invasion of privacy than the nighttime intrusion into a private hone"). In an unpublished dissertation that is credited by scholars and judges as an important source of Fourth Amendment history, see George C. Thomas III, Remapping The Criminal Procedure Universe, 83 Va. L. Rev. 1819, 1828 (1997) (book review) (referring to various citations of this work by scholars and judges), William John Cuddihy observes that the framers of the Fourth Amendment were strongly opposed to nighttime searches. See William John Cuddihy, The Fourth Amendment: Origins and Original Meaning, 602-1791, at 675-76, 1346, 1511 (1990) (unpublished Ph.D. dissertation, Claremont College) (on file with UMI Dissertation Service).

160. See Welsh, 466 U.S. at 753 (stating that "application of the exigent-circumstances exception in the context of a home entry should rarely be sanctioned when there is probable cause to beheve that only a minor offense, such as the kind at issue in this case, has been committed"); id. at 754 (indicating that "[t]he Supreme Court of Wisconsin let stand a warrantles:, nighttime entry into the petitioner's home to arrest him for a civil traffic offense," but: that "[s]uch an arrest ... is clearly prohibited by the special protection afforded the individual in his home by the Fourth Amendment" and "[t]he petitioner's arrest was therefore invalid"). 
fense") and the intrusiveness of the particular search (a person's home, at night). The Court effectively conducted a species of reasonableness balancing that took seriously the substantive questions involved in the particular search rather than either formalistically applying a purely quantitative standard, or alternatively applying a deferential standard by which virtually all ordinary law enforcement activity would be deemed legal. ${ }^{161}$ Despite the Court's sincere efforts, however, its approach in Welsh ultimately mirrors the imprecision evident in Payton and Steagald: There is no real substantive scrutiny, and the warrant requirement is misused.

First, the Court could have focused upon the actual substantive content of the offense in question (driving while intoxicated) and decided the case on the basis of a judgment about its seriousness relative to the intrusions at issue. Instead, the Welsh Court specifically disavowed any judicial judgment about the significance of the actual violation in question and deferred instead to Wisconsin's classification of the, offense as "civil" in deciding the case. ${ }^{162}$ If Wisconsin were unhappy with the Court's decision, it could, therefore, nullify it prospectively by simply changing (legislatively) the status of driving while intoxicated from a civil violation to a criminal offense. ${ }^{163}$

161. See infra notes 169-175, 178-179, 181, 183, and accompanying text (discussing, respectively, the Zurcher majority opinion and the drug testing cases: Vernonia Sch. Dist. 47J v. Acton, 515 U.S. 646 (1995), Skinner v. Railway Labor Executives' Ass'n, 489 U.S. 602 (1989), and National Treasury Employees Union v. Von Raab, 489 U.S. 656 (1989)). But see Chandler v. Miller, 520 U.S. 305, 321-23 (1997) (holding that candidates for political office could not be required to take a drug test as a prerequisite to running for political office, in spite of the flexible reasonableness-balancing approach, the importance of drug enforcement, and the limited nature of the intrusion, because there was no evidence that drug abuse was a problem among candidates for political office).

162. See Welsh, 466 U.S. at 754 n.14 (explaining "[n]or do we mean to suggest that the prevention of drunken driving is not properly of major concern to the States" but "[t] he State of Wisconsin, . . . along with several other States, . . . has chosen to limit severely the penalties that may be imposed after a first conviction for driving while intoxicated" and "[g]iven that the classification of state crimes differs widely among the States, the penalty that may attach to any particular offense seems to provide the clearest and most consistent indication of the State's interest in arresting individuals suspected of committing that offense" (citations omitted) (emphasis added)); see also id. at 755-56 (Blackunun, J., concurring) (declaring that "I yield to no one in my profound personal concern about the unwillingness of our national consciousness to face up to-and to do something about-the continuing slaughter upon our Nation's highways, a good percentage of which is due to drivers who are drunk or semi-incapacitated because of alcohol or drug ingestion," and noting that "it is amazing to me that one of our great States-one which, by its highway signs, proclaims to be diligent and emphatic in its prosecution of the drunken driver-still classifies driving while intoxicated as a civil violation ... so long as it is a first offense," but concluding that "if Wisconsin and other States choose by legislation thus to regulate their penalty structure, there is, unfortunately, nothing in the United States Constitution that says they may not do so" (emphasis in original)).

163. See Stuntz, Criminal Justice, supra note 56, at 54; cf. Colb, Incarceration, supra note 14 , at 792-94 ("the only substantive component of a 'valid' conviction is that the 
In addition to failing to take into consideration the content of the "civil" violation at issue in performing its substantive analysis, the Court in Welsh relied upon the warrant requirement to void an arrest the unreasonableness of which does not appear to have turned in any way upon the lack of what an arrest warrant might have provided (i.e., greater objectivity on the question of probable cause to arrest). In its opinion invalidating the arrest, the Court called attention to the great invasiveness of a nighttime intrusion into a person's home and bedroom. ${ }^{164}$ Rather than apply a balancing test that might consider this invasiveness as part of the analysis, however, the Court invoked the warrant requirement once again, as it did. in Payton and Steagald, as a substitute for substantive protection against unnecessary and disproportionately harsh investigative measures. Instead of holding that in the case of a truly minor offense, the police may not enter a person's home during the night to arrest him at all, the Court, by implication, held that the police could legally do exactly what they had done in this case, as long as they first obtained a warrant certifying probable cause to believe that Welsh had been driving while intoxicated, a fact about which there appeared to be no dispute. ${ }^{165}$ If the police had managed to obtain a warrant in this case, that would not have improved any of the features of the situation that seemed to trouble the Court - the intrusiveness of a home arrest, at night, along with the (at least formally) minor nature of the offense in question.

Payton, Steagald, and Welsh collectively illustrate the Supreme Court's rudimentary recognition of the need for Fourth Amendment substantive balancing, even as they also reveal the Court's grasping for the wrong

criminal conduct not be constitutionally protected as a fundamental right," so that "[g]overnments rnay, in other words, place behind bars those who engage in trivial, nonthreatening activity, provided the activity is prohibited by the criminal law and does not qualify as a fundamental right"); id. at 791 (observing that "[ $\mathrm{t}]$ hough liberty from confinement is an essential, core right of citizenship, a criminal conviction nonetheless extinguishes that right").

164. See Welih, 466 U.S. at 754.

165. The identity of the offender in this case was clear from the outset. A witness pointed out to the police the car that had been involved in the DWI incident. See Welsh, 466 U.S. at 742. The Court has repeatedly held that such a neutral witness's observations may be credited by police without any special additional showing. See lllinois v. Gates, 462 U.S. 213, 233-34 (1983) (explaining that "if an unquestionably honest citizen comes forward with a report of criminal activity-which if fabricated would subject him to criminal liability--we liave found rigorous scrutiny of the basis of his knowledge unnecessary"); Aclams v. Williams, 407 U.S. 143, 147 (1972) (indicating that "in some situations-for example, when the victim of a street crime seeks immediate police aid and gives a description of lis assailant, or when a credible informant warns of a specific impending crime-the subtleties of the hearsay rnle sliould not thwart an appropriate police response") Jaben v. United States, 381 U.S. 214, 221-22, 224 (1965) (explaining that because its information came from interviewing "third parties with whom the said taxpayer did busin ess" and "third persons having knowledge of the said taxpayer's financial condition," that "whereas some supporting information concerning the credibility of informants in narcotics cases or other common garden varieties of crime may be required, sucl information is not so necessary in the context of the case before us"). 
tools. ${ }^{166}$ Justice Stevens furnishes a model for a more coherent approach in his dissenting opinion in Zurcher $v$. Stanford Daily. ${ }^{167}$ Zurcher presented the issue whether a heightened standard for authorizing a search should apply to situations in which the person searched is an innocent third party and/or a newspaper (whose privacy might be necessary to a robust free press). ${ }^{168}$

The lower courts held that in the case of a search of either an innocent third party or a newspaper, Fourth Amendment reasonableness demands some showing of necessity in addition to the quantitative probable cause standard. ${ }^{169}$ These courts theorized that, because such searches are more intrusive and more constitutionally problematic than the search of a criminal suspect's home, they should be avoided, through the use of a subpoena, if at all feasible. ${ }^{170}$ A majority of the United States Supreme Court rejected the lower court's heightened reasonableness analysis and referred approvingly to the probable cause standard, which transcends the particular consequences of permitting a search in any given con-

166. Christopher Slobogin's proposal regarding proportionality is similarly incomplete. See generally Slobogin, supra note 12. Slobogin's vision of proportionality analysis speaks primarily to the relationship between the intrusiveness of a given search or seizure and the quantitative standard appropriate to performance of that search or seizure (what Slobogin terms the "certainty requirement"). See id. at $38,47,49-50,68$. Where Slobogin discusses the possible link between the strength of the governmental interest pursued (what Slobogin terms "harm severity") and the corollary demands of the Fourth Amendment, he confines his analysis to a consideration of the possible lowering of the quantitative standard in the presence of strong governmental interests, a possibility that he ultimately rejects. See id. at 51-52. By contrast to my proposed regime, then, Slobogin's program fails to consider banning altogether some kinds of generally allowable species of searches or seizures (such as traffic stops or home searches), in those cases in which the government lacks a sufficiently compelling interest (regardless of bow high the quantitative level of certainty preceding the search might be). Examples might include home searches for evidence of illicit drug possession, the chemical analogue of obscenity possession, and vehicular stops for technical traffic offenses that failed to create any substantial danger. See infra notes 238-248 and accompanying text (analyzing the Court's decision in Stanley v. Georgia, 394 U.S. 557 (1969), as a Fourth Amendment decision); supra notes $41-50$ and accompanying text (supporting the objective reasonableness test proposed by the petitioner in Whren v. United States, 517 U.S. 806 (1996)).

167. 436 U.S. 547, 577 (1978) (Stevens, J., dissenting).

168. Zurcher, 436 U.S. at 560-61 (discussing the question regarding an innocent third party); id. at 563-66 (discussing First Amendment implications of searching a newspaper); see also Stanford Daily v. Zurcher, 353 F. Supp. 124, 131-32, 135 (N.D. Cal. 1972) (addressing innocence and free press concerns), aff'd, 550 F.2d 464 (9th Cir. 1977), rev'd, 436 U.S. 547 (1978).

169. See Zurcher, 436 U.S. at 552-53.

170. See id. The intrusiveness of the innocent-third-party search derives in part from the search target's failure to act in any way to waive the privacy that would be subject to invasion. For a discussion of what it would mean for a person to "waive" or forfeit some of his privacy and of what role imnocence might play in determining the scope of a person's Fourth Amendment entitlements, see generally Colb, Innocence, supra note 9. For a detailed examination of Zurcher in connection with innocence-related questions, see id. at 1503-09. 
text. ${ }^{171}$ The Court held that the search of a news office for photographic evidence of a crime in which the newspaper itself was not implicated could legally proceed on the basis of a warrant and probable cause alone. ${ }^{172}$

In his dissenting opinion, Justice Stevens proposes that the police should have to demonstrate need before being permitted to search an innocent third party, because an innocent person is likely to cooperate with the police without having to endure the coercion and intrusion that accompany the search of a criminal suspect. ${ }^{173}$ Such a necessity requirement also would have effectively protected privacy in the home in the scenarios presented in Payton, Steagald, and Welsh. Requiring a warrant, by contrast, as the Court did in these cases, fell short of accomplishing these substantive ends.

\section{Reasonableness Balancing}

There is one set of cases in which the Court has been ready and willing to apply an open-ended reasonableness balancing standard in

171. See Zurcher, 436 U.S. at 554, 559; cf. Amsterdam, supra note 12, at 358 (arguing that "the definition of "reasonableness" turns, at least in part, on the more specific commands of the [Fourth Amendment's] warrant clause," which permits the issuance of warrants based upon a showing of probable cause (quoting United States v. United States District Court, 407 U.S. 297, 315 (1972) (alteration in original))).

172. See Zurcìer, 436 U.S. at 567.

173. See id. at 581 (Stevens, J., dissenting) ("Mere possession of documentary evidence . . . is much less likely [than possession of contraband] to demonstrate that the custodian is guilty of any wrongdoing or that he will not honor a subpoena or informal request to produce it."); see also Colb, lnnocence, supra note 9, at $1508 \mathrm{n} .131$ (observing that "[i]t is Justice Stevens's position that the rule prior to Warden v. Hayden, 387 U.S. 294 (1967) was the 'correct' reading of the Fourth Amendment: warrants could be used only to search for contraband, weapons, and plunder, not for 'mere evidence'" (citing Hayden, 387 U.S. at 301)); id. (noting that, according to Justice Stevens, the "mere evidence" rule of Hayden "guaranteed that only when it seemed likely that the object of the search would be uncooperative--because he had apparently participated in the relevant crime-could a search take place" but that "[i]f the person in whose possession the evidence was located was an imnocent third party, however, efforts would be made to avoid a search through the cooperation of the individual" (citing Zurcher, 436 U.S. at 581 (Stevens, J., dissenting))). For an alternative analysis of the mere-evidence rnle in the context of Fourth Amendment privacy and property interests, see Daniel B. Yeager, Search, Seizure and The Positive Law: Expectations of Privacy Outside The Fourth Amendment, 84 J. Crim. L. \& Criminology 249 (1993).

In a separate dissenting opinion, Justice Stewart addresses the special importance that attaclies to an official search of a newspaper office, particularly given the historical importance of the free press ideal in motivating the framing of the Fourth Amendment. See Zurcher, 436 U.S. at 571-76 (protesting that "we are here to uphold a Constitution" and that "our Constitution ... explicitly protect[s] the freedom of the press"); see also Potter Stewart, The Road to Mapp v. Ohio and Beyond: The Origins, Development and Future of the Exclusionary Rule in Search-and-Seizure Cases, 83 Colum. L. Rev. 1365, 1369-70 (1983). 
place of the probable cause and warrant requirements. ${ }^{174}$ These cases are distinguished, however, not by exacting demands but by a relaxed and deferential approach to the balancing at hand. The Court applies the approach in settings implicating "special" law enforcement interests distinct from the ordinary criminal investigative variety. These interests include such diverse objectives as preventing undocumented foreign nationals from crossing United States borders, ${ }^{175}$ governing public schools, ${ }^{176}$ and regulating public employees. ${ }^{177}$ Although the Court occasionally holds that searches and seizures in these areas violate Fourth Amendment reasonableness, ${ }^{178}$ the conclusion that usually follows from the Court's classification of a case as implicating a "special" law enforcement interest calling for reasonableness balancing is the approval of the government's actions with little inquiry into the governmental needs

174. Scott Sundby urges strict scrutiny as the appropriate standard of reasonableness analysis for initiatory intrusions (intrusions that are not based upon an individualized suspicion of wrongdoing). In his view, "[ $t]$ he compelling government interest-least intrusive means test would narrow the realm of initiatory intrusions primarily to situations in which the government can demonstrate that lack of immediate action endangers the public's safety." Sundby, Undoing The Mischief, supra note I8, at 442 . Like me, Sundby sees an important role for a substantive Fourth Amendment reasonableness analysis in which the government must have a very important interest before it may intrude upon what I have termed ordimary privacy interests. Where we differ is on the proper scope of substantive analysis. Sundby would apply strict scrutiny only to cases in which the government lacks a warrant and individualized probable cause. I would, by contrast, require that even a search that is supported by probable cause and a warrant be subject to something akin to the compelling interest analysis that Sundby describes, to prevent legislatures from defining substantive criminal law so expansively that the probable cause and warrant requirements provide almost no protection. See supra notes $65-68$ and accompanying text.

175. See Ronald J. Allen, et al., supra note I47, at 809 (reviewing the history of congressional and judicial approval of the notion that " $[t]$ he routine search of a person and the person's baggage upon entering the country need not be based on even reasonable suspicion").

176. See Vernonia Sch. Dist. 47J v. Acton, 515 U.S. 646, 663-65 (1995) (holding that a public school may subject students on athletic teams to random, suspicionless drug tests); New Jersey v. T.L.O., 469 U.S. 325, 340-41 (1985) (holding that a principal may search the pocketbook of a student for evidence of scliool rules violations without a warrant or probable cause).

177. See, e.g., Skinner v. Railway Labor Executives' Ass'n, 489 U.S. 602, 633-34 (1989) (holding that a public railroad could, without particularized suspicion, randomly test its employees for drugs after a train accident in accordance with FRA regulations); National Treasury Employees Union v. Von Raab, 489 U.S. 656, 679 (1989) (upholding under Fourth Amendment reasonableness balancing the suspicionless testing of employees who apply for promotions to positions that directly involve the interdiction of illegal drugs or require the incumbent to carry a firearm); O'Connor v. Ortega, 480 U.S. 709, 719-26 (1987) (plurality opinion) (holding that public employer could search an employee's office without a warrant or probable cause).

178. See Chandler v. Miller, 117 S. Ct. 1295, 1303-05 (1997) (holding that candidates running for political office may not be required to undergo drug testing, because, even though the drug test is not very intrusive, there must be some showing of need to justify the test, and this showing was not met here). 
served or the relative gravity of the intrusion involved. ${ }^{179}$ Some commentators have even gone so far as to suggest that the Court's reasonableness balancing cases are characterized by their very failure to engage in any actual balancing. ${ }^{180}$

However charitably one describes the "reasonableness balancing" cases, the substantive reasonableness standard I propose here is distinct from the kind of "balancing" that characterizes those cases. Even the argument that some governmental interests are important or special enough to merit an alternative "reasonableness balancing" approach implicitly assumes that such balancing will be less demanding of the government (and therefore more accommodating to the "special" interests) than the probable cause and warrant requirements from which they constitute a departure. ${ }^{181}$

179. See T.L.O., 469 U.S. at 369 (Brennan, J., dissenting in part) (suggesting that "[a]ll of these 'balancing tests' amount to brief nods by the Court in the direction of a neutral utilitarian calculus while the Court in fact engages in an unanalyzed exercise of judicial will"); id. at 357-58 (contending that "[t]he Court's decision jettisons the probable-cause standard-the only standard that finds support in the text of the Fourth Amendment - on the basis of its Rohrschach-like 'balancing test"); see also Skinner, 489 U.S. at 636, 639 (Marshall, J., dissenting) (claiming that " $[t]$ he Court today takes its longest step yet toward reading the probable-cause requirement out of the Fourth Amendment" and that "the Court has now permitted 'special needs' to displace constitutional text in each of the four categories of searches enumerated in the Fourth Amendment" so that "[t]ellingly, each time the Court has found that 'special needs' counseled ignoring the literal requirements of the Fourth Amendment for such full-scale searches in favor of a formless and unguided 'reasonableness' balancing inquiry, it has concluded that the search im question satisfied that test").

180. See Tracey Maclin, Constructing Fourth Amendment Principles from the Government Perspective: Whose Amendment Is It, Anyway?, 25 Am. Crim. L. Rev. 669, 719 (1988) (arguing that "[d]espite its label, the so-called 'special needs' formula has not been confined to cases where intrusive police conduct was necessitated by emergency conditions" and that "although the Court denies it, the special needs formula diminishes the fourth amendment rights of individuals subjected to governmental intrusions sanctioned by this doctrine" because "[t]he Court emphasizes the needs of government, while offering only token attention to the privacy interests at stake and the benefits provided by the probable cause and warrant rules," so, "[i]n short, the special needs formula ultimately reflects a governmental perspective in interpreting the fourth amendment").

181. See Von Raab, 489 U.S. at 667 (asserting that " $[\mathrm{t}]$ he Customs Service has been entrusted with pressing responsibilitics, and its mission would be compromised if it were required to seek search warrants in connection with routine, yet sensitive, employment decisions"); Skinner, 489 U.S. at 620 (contending that " $[t]$ he Government's interest in regulating the conduct of railroad employees to ensure safety ... "presents "special needs" beyond normal law enforcement that may justify departures from the usual warrant and probable-cause requirements" (quoting Griffin v. Wisconsin, 483 U.S. 868, 873-74 (1987))); O'Conncr, 480 U.S. at 722 (maintaining that "[i]mposing unwieldy warrant procedures [in cases in which the employer wishes to enter an employee's office, desk, or file cabinets for a work-related purpose]. . . . would conflict with 'the common-sense realization that government offices could not function if every employment decision became a constitucional matter" (quoting Connick v. Myers, 461 U.S. 138, 143 (1983))); T.L.O., 469 U.S. at 341 (concluding that "the accommodation of the privacy interests of schoolchildren with the substantial need of teachers and administrators for freedom to 
One exception among the Court's "reasonableness" balancing cases which stands out for its subtlety and sensitivity to both sides of the intrusion/need equation is Terry $v$. Ohio. ${ }^{182}$ Terry involved an experienced police officer who had noticed several men pacing back and forth in front of a store and interacting with one another in an otherwise suspicious fashion. The officer, after observing several repetitions of what seemed like ritualistic pacing, concluded that the men were preparing to rob the store in question. ${ }^{183}$ The officer confronted the men and asked questions, the answers to which did not dispel his suspicions. The officer searched the suspects for weapons and found that two of the men were armed. The two men were subsequently convicted of carrying concealed weapons. On the appeal of their convictions, the Supreme Court faced the issue of the Fourth Amendment implications-if any-of such an onthe-street encounter.

In deciding the question, the Court considered the argument that this sort of encounter, which may include the stopping and frisking of potential suspects for weapons, ought to lie completely outside the coverage of the Fourth Amendment. ${ }^{184}$ The police need flexibility, the argument went, in dealing with situations that arise in their presence and that do not call for, or allow time for, obtaining a search warrant. Since a stop is less severe than an arrest and a weapons frisk is less intrusive than a typical search, it would be fair, on this reasoning, to classify stops and frisks as falling outside the scope of the terms "search" and "seizure," set out and regulated by the Fourth Amendment. ${ }^{185}$

The petitioner opposed such classification and argued that stops and frisks should receive the same Fourth Amendment treatment that is accorded other seizures and searches identified by the Court. ${ }^{186}$ Accepting the petitioner's proposal to apply the probable cause and warrant requirements to stops and frisks, however, would have made it exceedingly difficult for the police to intervene in criminal activity before or during

maintain order in the schools does not require strict adherence to the requirement that searches be based on probable cause" and suggesting that even the reduced level of individualized suspicion present on the facts of T.L.O. might not be required).

182. 392 U.S. 1 (1968). For an extensive discussion of the sensitivity of the Court's balancing in Terry and a corresponding critique of the Court's failure to live up to Terry's promise, see Gregory H. Williams, The Supreme Court and Broken Promises: The Gradual But Continual Erosion of Terry v. Ohio, 34 How. L.J. 567 (1991) [hereinafter Williams, Broken Promises]. But see Sundby, Undoing the Mischief, supra note 18, at 385 (criticizing the Court's reasoning in Terry $v$. Ohio and faulting it along with Camara v. Municipal Court, 387 U.S. 523 (1967), for the later devolution of "reasonableness balancing").

183. See Terry, 392 U.S. at 6.

184. See id. at 16 (stating that "[t]here is some suggestion in the use of such terms as 'stop' and 'frisk' that such police conduct is outside the purview of the Fourth Amendment because neither action rises to the level of a 'search' or 'seizure' withim the meaning of the Constitution").

185. See id.

186. See id. at 25 . 
its occurrence, because the process of obtaining a warrant assumes that a crime has already taken place and that what remains to be done is the apprehension of suspected criminals and the seizure of evidence.

The Supreme Court, in a now-famous opinion by Chief Justice Earl Warren, announced that the law enforcement interest in confronting people who appear to be about to commit a crime is a "special" law enforcement interest of the sort that should trigger a reasonableness balancing approach rather than the usual probable cause and warrant requirements. ${ }^{187}$ In later cases, as we have seen, such an announcement would come (in most circumstances) to decide the controversy. If a "special" law enforcement interest were at stake, the Court would perform a deferential, ad hoc balancing test, often without much analysis beyond the announcement itself, and would conclude with a determination that the proposed governmental activity did not offend the requirements of the Fourth Amendment. ${ }^{188}$ By contrast, the application of reasonableness balancing in Terry commenced rather than concluded the analysis.

The Court considered and rejected the proposal that stops and frisks be declared a Fourth Amendment-free zone. It emphasized how frightening, intrusive, and humiliating it is for a person to be stopped and frisked by the police in public, even though a stop may not last as long as a garden-variety arrest, and a frisk may not be as thorough as a typical search. ${ }^{189}$ The Court also, however, took seriously the notion that one important job of the police is to prevent crimes that are about to happen, rather than just: to solve completed crimes reactively. ${ }^{190}$

The decision of the Court ultimately approved the measures taken by the officer who had apprehended Terry and his co-arrestees. As Justice Harlan emphasized in his concurring opinion, though, stops and frisks would qualify as seizures and searches under the Fourth Amendment and would accordingly require support in each case by objective, articulable facts that would lead a person of reasonable caution to conclude that criminal activity was afoot and that the person to be frisked was armed and potentially dangerous. ${ }^{191}$ Given the spontaneity of such police work, it would not be realistic to require a search warrant. A probable cause requirement would also defeat the purpose of preliminary and preventive

187. See id. at 27.

188. See, e.g., Vernonia Sch. Dist. 47J v. Acton, 515 U.S. 646, 652-54 (1995); National Treasury Employees' Union v. Von Raab, 489 U.S. 656, 665-66 (1989); Skinner v. Railway Labor Executives' Ass'n, 489 U.S. 602, 618-20 (1989); O'Connor v. Ortega, 480 U.S. 709, 719-26 (1987) (plurality opinion); Camara v. Municipal Court, 387 U.S. 523, 534-39 (1967); see also New Jersey v. T.L.O., 469 U.S. 325, 341 (1985) (“[T] he accomodation of the privacy interests of school children with the substantial need of teachers and administrators for freedom to maintain order in the schools does not require strict adherence to the requirement that searches be based on probable cause to believe that the subject of the search has violated or is violating the law.").

189. See Terry, 392 U.S. at 24-25.

190. See id. at 22.

191. See id. at 32-33 (Harlan, J., concurring). 
intervention. ${ }^{192}$ The Court held, however, that the police could not legally act entirely on the basis of their subjective hunches or intuitions. ${ }^{193}$ A decision to stop or frisk would be subject to judicial review under a reasonable-person standard. ${ }^{194}$

The Court's approach in Terry provides a useful illustration of what a generally applicable substantive reasonableness scrutiny might look like. The majority explicitly applied a reasonableness-balancing test that, in the particular case, relaxed the usual demands of the Fourth Amendment. It did so without suspending the quantitative requirement of individualized suspicion. The Court thereby demonstrated that resort to reasonableness balancing might comfortably go hand in hand with a requirement that virtually any individual intrusion, regardless of how different from the usual investigative pursuits of law enforcement, must be based upon evidence tending to show that the particular person to suffer the intrusion was engaged in criminal or otherwise illegal activity. ${ }^{195}$ As in the cases applying a heightened reasonableness standard, ${ }^{196}$ then, the balancing test in Terry did not amount to carte blanche for law enforcement.

In addition to having retained an individualized suspicion component in a reasonableness balancing context, the Terry decision is noteworthy for a second reason as well. In Terry, the "special" law enforcement interest at stake appeared implicitly to limit the application of the new standard. The reasonable-suspicion standard, in other words, would seem, on the Court's reasoning, to apply only to factual scenarios implicating the rationale articulated for the distinctive treatment of such cases, namely, the need to prevent crime and disarm dangerous people. In a concurring opinion, Justice Harlan made this caveat explicit. He asserted that a police officer could not initiate an encounter with a suspect without a justification and expect to be authorized to frisk the suspect on the basis of the real danger that such encounters will predictably entail:197

[I] $\mathrm{f}$ the frisk is justified in order to protect the officer during an encounter with a citizen, the officer must first have constitutional grounds to insist on an encounter, to make a forrcible stop. Any person, including a policeman, is at liberty to avoid a person he considers dangerous. If and when a policeman has a right instead to disarm such a person for his own protection, he

192. See id. at 20.

193. See id. at 22.

194. See id. at 27.

195. Some categories of searches might legitimately occur in the absence of probable cause and a warrant and even in the absence of individualized suspicion. See supra notes 19-20.

196. See Tennessee v. Garner, 471 U.S. 1 (1985) (holding that use of deadly force against unarmed fleeing suspect was an unreasonable seizure); Winston v. Lee, 470 U.S. 753 (1985) (holding unconstitutional court-ordered surgical reinoval of bullet from suspect's body).

197. See Terry, 392 U.S. at 32 (Harlan, J., concurring). 
must first have a right not to avoid him but to be in his presence. ${ }^{1918}$

If we examine the import of Justice Harlan's opinion, we see that he did not mean to suggest that the police should run the other way (as civilians might do) whenever they observe threatening, dangerous individuals in the vicinity. Instead, Justice Harlan implicitly acknowledged that once a police officer has stopped a suspect, it would often follow that the officer might legitimately fear for his safety. Justice Harlan understood that such confrontations-including the vehicle stops that occur regularly-are fraught with potential misunderstandings that could ultimately prove fatal. ${ }^{199}$ Therefore, Justice Harlan proposed that the stop of a suspect is itself a critical event that almost automatically generates a dangerousness concern that authorizes a weapons frisk of the suspect. ${ }^{200}$ Accordingly, Justice Harlan insisted that the stop should be undertaken only when truly justified. Such justification, given the potential for escalation and violence, might arguably entail the scenario of a developing, serious crime, such as the crime that was at issue in Terry itself.

Consider how the post-Terry cases involving stops (of vehicles and pedestrians) might have been decided if Justice Harlan's concurrence and the principles embedded in its logic had been adopted explicitly as part of the majority opinion. First, only crimes that might yet be nipped in the bud or ctherwise frustrated would trigger the application of the Terry analysis and its exception to the warrant and probable cause requirements. The "stop" of a suspect in connection with a completed crime would accordingly not be authorized on reasonable suspicion alone. Second, the stop of a person as to whom the police had reasonable suspicion with respect to a future crime would not necessarily be authorized in every case. There would be times when the police would have to avoid the danger of an encounter just like everyone else. ${ }^{201}$ The "stop" would be limited to serious crimes, so that the intrusion of a stop along with the accompanying potential for dangerous and even fatal outcomes could be substantively justified. Borrowing from the Court's analogous statement about the use of deadly force in Gamer, we could say that it is not better that all minor crimes be prevented through potentially

198. Id.

199. See supra note 48 (quantifying the danger of vehicle stops).

200. Daniel Yeager has similarly suggested that Justice Harlan "wrote separately in Terry to express his view that the right to frisk follows automatically from the right to stop." Daniel Yeager, Searches, Seizures, Confessions, and Some Thoughts on Criminal Procedure: Regulation of Police Investigation-Legal, Historical, Empirical, and Comparative Materials, 23 Fla. St. U. L. Rev. I043, 1054 (1996). Yeager also opined that Justice Harlan's view constitutes the current legal practice (at least with respect to the dual authority to stop and frisk, if not with respect to the substantively meaningful standard for the initial stop). "Indeed," Yeager argues, "the behaviors [stop and frisk] are so intertwined that often, as it was in Terry, it is the frisk that alerts us to the fact that a stop has taken place." Id.

201. See Terry, 392 U.S. at 32-33 (Harlan, J., concurring). 
violent confrontations between suspects and police than that some minor crimes be allowed to take place without intervention. ${ }^{202}$ The police could thus only stop and frisk those suspects reasonably suspected of preparing to engage in a potentially violent or otherwise serious crime.

In the years following Terry, the Court steadily moved further away from the principle of limiting the stop-and-frisk authority to the crimeprevention context. In 1985, the Court explicitly upheld stops and frisks that occurred in connection with completed felonies. ${ }^{203}$ It also permitted Terry stops and frisks in the case of reasonably suspected narcotics possession offenses, in which there is no necessary safety risk attached to the suspected activity. ${ }^{204}$ Rather than representing a qualitatively distinct circumstance, the on-the-street police encounter thus came to embody a species of intrusion that, because less extensive than an arrest and a full search, would be authorized on a standard that was quantitatively less demanding but substantively very much like the probable cause standard. ${ }^{205}$

$$
* * *
$$

As we have seen, the Court has assembled in a variety of cases the raw materials for what could develop into a robust substantive reasonableness approach to Fourth Amendment questions. In the context of extraordinarily intrusive searches and seizures, the Court has explicitly announced substantive balancing tests that require more than a quantitative showing of probable cause and a valid warrant. In the context of more conventional police intrusions, the Court has distinguished, albeit awkwardly, between public arrests and home arrests, as well as between daytime home arrests and nighttime home arrests. Such distinctions reveal a judi-

202. Cf. Tennessee v. Garner, 471 U.S. 1, 11 (1985) (concluding that "[i]t is not better that all felony suspects die than that they escape").

203. See United States v. Hensley, 469 U.S. 221, 229 (1985) (upholding stop of an armed robbery suspect and indicating that although "[w] ne need not and do not decide today whether Terry stops to investigate all past crimes, however serious, are permitted.... [i]t is enough to say that, if the police have a reasonable suspicion, grounded in specific and articulable facts, that a person they encounter was involved in or is wanted in connection with a completed felony, then a Terry stop may be made to investigate that suspicion").

204. See United States v. Sokolow, 490 U.S. 1, 7 (1989) (approving a stop that was based on application of the drug courier profile and indicating that prohibiting such a stop would have "serious implications for the enforcement of the federal narcotics laws"); Adams v. Williams, 407 U.S. 143, 151 (1972) (Brennan, J., dissenting) (embracing the view articulated in a dissent by Judge Friendly in the Second Circuit Court of Appeals, expressing "the gravest hesitancy in extending [the holding in Terry] to crimes like the possession of narcotics," noting the "danger that, imstead of the stop being the object and the protective frisk an incident thereto, the reverse will be true" (quoting Williams v. Adams, 436 F.2d 30, 38 (2d Cir. 1970) (Friendly, J., dissenting))); see also Williams, Broken Proinises, supra note 182, at 578-79 (describing this expansion of police authority to stop and frisk that occurred in the cases that succeeded Terry).

205. See, e.g., Alabama v. White, 496 U.S. 325, 330-31 (1990) (applying a totality-ofthe-circumstances approach to reasonable suspicion, analogous to probable cause as elaborated in Illinois v. Gates, 462 U.S. 213 (1983), "the only difference [between Illinois $v$. Gates and Alabama $v$. White] being the level of suspicion that must be established"). 
cial inclination to permit a greater consideration of substance in evaluating even routine, ordinary searches and seizures. Finally, the Court has constructed a cloctrine of "reasonableness balancing" in which "special" law enforcement interests permit the police to forego both probable cause and a warrant. Though this class of cases has devolved into a deferential approach to a variety of searches and seizures, the case in which the approach was originally developed-Terry $v$. Ohio-contains a sophisticated analysis that could have led, and might yet lead, to a less limited (and less deferential) substantive reasonableness balancing approach across the board.

Until this point, we have examined case law in the Fourth Amendment area illustrating the Court's reluctance to apply a genuinely demanding substantive balancing test in most of its criminal procedure precedents, in spite of its own sense of the tension between the need for greater protection of ordinary privacy and a purely quantitative approach available in all but extraordinary circumstances. We turn in the next Part to a set of cases in which the Court has been comfortable applying substantive balancing tests comparing the strength of governmental interests, on the one hand, with the intrusiveness of government practices on individual privacy, on the other. These cases proceed outside of the criminal procedure context in what is known as the law of substantive due process. Part III draws on the methods employed by the Court in this legally distinct category of cases to develop a framework for understanding the consequences of a purely quantitative Fourth Amendment privacy doctrine, both on privacy from unreasonable searches as well as on the independent vitality of the substantive due process entitlements.

\section{Linking the Two KInds of Privacy}

The Court has in the last century been relatively daring in balancing interests regarding constitutional claims of right under the Fifth and Fourteenth Amendments' Due Process Clauses. Specifically, the Court has performed an exacting balancing test in assessing government interference with what are known collectively as substantive due process "privacy" rights. Such rights include decisions about whether or not to have children and, for people who have children, decisions about the upbringing and education of those children. ${ }^{206}$ By referring to both Fourth Amendment rights and substantive constitutional law entitlements as features of "privacy;" the Court has, perhaps without intending to do so, invited us to forge links between the logic of Fourth Amendment doctrine and the content of the particular liberties constituting substantive due process.

206. See, e.g., Flanned Parenthood v. Casey, 505 U.S. 833 (1992); Roe v. Wade, 410 U.S. 113 (1973); Eisenstadt v. Baird, 405 U.S. 438 (1972); Griswold v. Connecticut, 381 U.S. 479 (1965); Pierce v. Society of Sisters, 268 U.S. 510 (1925). 


\section{A. The Private Bedroom}

The decision that most explicitly calls attention to the connection between substantive due process privacy and Fourth Amendment privacy is Griswold v. Connecticut. ${ }^{207}$ Griswold involved a challenge to a law banning the use of contraceptives. In finding the law to be an unconstitutional violation of marital privacy, the Court explained, "[v]arious guarantees [in the Bill of Rights] create zones of privacy,"208 and "[t]he Fourth Amendment explicitly affirms the "right of the people to be secure in their persons, houses, papers, and effects, against unreasonable searches and seizures." "209 Fourth Amendment privacy, in other words, is a relevant source of law with respect to a couple's use of contraceptives.

How does this work? How would freedom from searches and seizures absent probable cause or a warrant bear on whether the state might ban the use of contraceptives? Justice Douglas, writing for the majority, suggests an answer with a question of his own: "Would we allow the police to search the sacred precincts of marital bedrooms for telltale signs of the use of contraceptives? The very idea is repulsive to the notions of privacy surrounding the marriage relationship." 210 The enforcement of a law banning the use of contraceptives, in other words, might require searches of these "sacred precincts," and such searches would unconstitutionally undermine the privacy of the marital relationship. ${ }^{211}$

This logic appears flawed, at least under familiar constitutional principles. The Fourth Amendment generally requires that police only search and seize once they have probable cause to believe they will find evidence of crime. Whether evidence of a specific activity constitutes evidence of "crime" depends, in turn, upon whether the particular jurisdiction has a criminal statute banning the activity. Connecticut was a jurisdiction having such a statute concerning the use of contraceptives when Griswold came before the United States Supreme Court. It would seem, therefore, to follow that a search of a Connecticut couple's bedroom for

207. 381 U.S. 479 (1965).

208. Id. at 484 .

209. Id. (quoting U.S. Const. amend. IV).

210. Id. at $485-86$.

211. See Poe v. Ullman, 367 U.S. 497, 509 (1961) (Douglas, J., dissenting). In Poe, Justice Douglas elaborated in greater detail on the nature of his objection to laws banning the use of contraception by married couples:

The regulation as applied in this case touches the relationship between man and wife. It reaches into the intimacies of the marriage relationship. If we imagine a regime of full enforcement of the law in the manner of an Anthony Comstock, we would reach the point where search warrants issued and officers appeared in bedrooms to find out what went on .... [W] hen the State makes "use" a crime and applies the criminal sanction to man and wife, the State has entered the innermost sanctum of the home. If it can make this law, it can enforce it. And proof of its violation necessarily involves an inquiry into the relations between man and wife.

Id. at 519-21. 
"telltale signs of the use of contraceptives" would raise no Fourth Amendment difficulties as long as the police had probable cause to believe the bedroom contained such "telltale signs," along with a search warrant attesting thereto.

Furthermore, we might ask, what would be so repulsive about allowing the police to search marital bedrooms for evidence of contraceptive use? Certainly, if there were probable cause to believe that a murder, a rape, or a robbery were committed in the bedroom of a married couple, it would not have offended the Griswold Court to permit a search of the bedroom-and even a search of the bedroom for contraceptives, to the extent that such a search might help identify a suspect in connection with a violent crime. If the Court would not ban all searches of marital bedrooms, nor even all searches of marital bedrooms for contraceptives, then what did Justice Douglas and a majority of the Court mean by condemning the idea of a search for contraceptives in the marital bedroom?

Justice Douglas's opinion for the Court appears to have balanced what I have called the individual right of privacy from governmental personal knowledge against the government's interest in effectively fighting contraceptive use. Marital privacy (including the substantive right to marry, ${ }^{212}$ to have children, ${ }^{213}$ and to educate those children ${ }^{214}$ ) requires as a prerequisite a physical privacy from governmental personal knowledge of the married couple's home. If the government lacks a more compelling justification for searching a marital home than the interest in stamping out the crime of contraceptive use, then the search is accordingly an unreascnable one, because it exposes the sacred precincts of the marital quarters for an insufficiently important reason. It is this link that begins to provide a response to critics of the "privacy" nomenclature in defining substantive due process rights. ${ }^{215}$

Searches for evidence of murder, rape, or robbery would also undoubtedly intrude upon marital privacy. Such searches, however, do so in the service of more compelling governmental interests. Though the Court, since 1965, has come to embrace as an independently fundamental right the decision whether to beget and bear children, ${ }^{216}$ the language

212. See Zablcıcki v. Redhail, 434 U.S. 374, 383-84 (1978) (recognizing as fundamental the right to marry, though decided after Griswold).

213. See Skinner v. Oklahoma, 316 U.S. 535, 541-42 (1942) (finding a substantive right to procreate, in the context of an equal protection challenge).

214. See Pierce v. Society of Sisters, 268 U.S. 510, 534-35 (1925) (announcing a right to send children to private school); Meyer v. Nebraska, 262 U.S. 390, 403 (1923) (announcing a right to teach children a foreign language).

215. See, e.g., Henkin, supra note 114, at 1410-11 (suggesting that the "right of privacy' ... . denomination" for substantive due process protection "is misleading, if not mistaken" and that "[t]o date, at least, the right has brought little new protection for what most of us think of as "privacy'-freedom from official intrusion," and proposing that such rights are more appropriately viewed as autonomy entitlements).

216. See, e.g., Roe v. Wade, 410 U.S. 113, 169-70 (1973) (Stewart, J., concurring) (noting that the right to decide whether to bear or beget a child "necessarily includes the 
of the majority in Griswold itself seemed focused largely on honoring a married couple's need for physical, spatial privacy in facilitating their sacred association, rather than on recognizing a specific interest in avoiding conception. 217

Twenty-one years after the decision in Griswold, in Bowers v. Hardwick, the Court held that there is no privacy right among homosexuals to engage in acts of sodomy. ${ }^{218}$ The Court went on to announce that such acts could therefore be criminally prohibited. ${ }^{219}$ Justice Blackmun argued in an angry dissent that the Court should have invalidated the criminal statute at issue on the same logic that had dictated earlier privacy decisions regarding marriage and family.220 He declared further that " $[t]$ his case is no more about 'a fundamental right to engage in homosexual sodomy,' as the Court purports to declare, ... than Stanley v. Georgia was about a fundamental right to watch obscene movies, or Katz $v$. United States was about a fundamental right to place interstate bets from a telephone booth."221 I will address Stanley v. Georgia ${ }^{222}$ shortly, ${ }^{223}$ but let us first consider Justice Blackmun's reference to Katz, the 1967 case that ushered in the modern era of Fourth Amendment privacy jurisprudence.

At first blush, Justice Blackmun's statement appears to confuse two distinct sorts of rights. On the one side is the Fourth Amendment decision in Katz, which held that a police officer must have a warrant based upon probable cause before he may record a telephone conversation taking place inside a public telephone booth. ${ }^{224}$ As I have discussed else-

right of a woman to decide whether or not to terminate her pregnancy"); Eisenstadt v. Baird, 405 U.S. 438, 453 (1972) (holding that "[i]f the right of privacy means anything, it is the right of the individual, married or single, to he free from unwarranted governmental intrusion into matters so fundamentally affecting a person as the decision whether to bear or beget a child"); see also Planned Parenthood v. Casey, 505 U.S. 833, 846 (1992) (affirming "Roe's essential holding," including "a recognition of the right of the woman to choose to have an abortion before viability and to obtain it without undue interference from the State .... [whose pre-viability interests] are not strong enough to support a prohibition of abortion or the imposition of a substantial obstacle to the woman's effective right to elect the procedure").

217. Cf. Griswold v. Connecticut, 381 U.S. 479, 482-83 (1965) (noting “[w]ithout those peripheral rights [including the rights announced in Meyer and Pierce] the specific rights [listed in the Bill of Rights] would be less secure"). The primciple of some rights as prerequisites to the exercise of other rights is a familiar one. See, e.g., Gideon v. Wainwright, 372 U.S. 335, 344 (1963) (holding that "reason and reflection require us to recognize that in our adversary system of criminal justice, any person haled into court, who is too poor to hire a lawyer, cannot be assured a fair trial unless counsel is provided for him").

218. Bowers v. Hardwick, 478 U.S. 186 (1986).

219. See id. at 192-94.

220. See id. at 203-06 (Blackmun, J., dissenting).

221. Id. at 199 (Blackmun, J., dissenting) (citations omitted).

222. 394 U.S. 557 (1969).

223. See infra Section III.B.

224. Katz v. United States, 389 U.S. 347, 358 (1967) (explaining that the Court "cannot agree" that "surveillance of a telephone booth should be exempted from the usual requirement of advance authorization by a magistrate upon a showing of probable cause"). 
where, the Fourth Amendment warrant and probable cause requirements do not imply any approval or protection for the individual's engagement in criminal acts in private. ${ }^{225}$ From the perspective of the individual who commits his crimes behind closed doors, I have also argued that there exists no entitlement to maintain the privacy of the area in which the crime is taking place. ${ }^{226}$ The warrant and probable cause requirements function in this sense as imperfect proxies for the presence of criminal activity and evidence of criminal activity, so that the criminal act forfeits the right to privacy in the specific location containing hidden evidence of the act. ${ }^{227}$

By contrast, the asserted right of the respondent Michael Hardwick was the entitlement to privacy in his intimate associations, specifically the right to engage in consensual, sexual relationships with other men without governmental interference. ${ }^{228}$ Such a putative right is unlike the warrant and probalole cause requirements, which have nothing to do with the nature of the crime being investigated and do not turn on the legitimacy of criminalizing any particular conduct. ${ }^{229}$ Justice Blackmun appears, in other words, to have refused to acknowledge the fact that Hardwick was claiming a constitutional right to engage in acts of homosexual sodomy.

If we examine more closely the right asserted in Hardwick, however, we see that it truly is closely linked to Fourth Amendment privacy in one's home and, in particular, in one's bedroom. Like the petitioners in Griswold, Michael Hardwick did not assert that he had an absolute right to engage in consensual sexual practices with other men. The claimed right was place-specific: Hardwick asserted that the government should not have invaded the privacy of his home and his bedroom to investigate the

225. See Colb. Innocence, supra note 9, at 1466-68.

226. See id. at 1494-95 (suggesting that "if an individual deserves to be searched because he has engaged in concealment for which he would have been legally subject to a search had the police officer known of that concealment, that individual does not deserve privacy from the search, even though he deserves not to be searched because of an arbitrary decision to target him," and that "[i] t is accordingly not clear that we should 'reinstate' his privacy by overloo"king any evidence found in his possession" since "[t]he individual's privacy was appropriately invaded; it was the unreasonableness of the search that constituted the wrongdoing and that should therefore be rectified").

227. See id. at 1477 (contending that " [p]robable cause is thus an imperfect proxy for ensuring that the official will find evidence concealed on the person or property of any individual searchec").

228. See Laurence H. Tribe \& Michael C. Dorf, Levels of Generality in the Definition of Rights, 57 U. Chi. L. Rev. 1057, 1065-66 (1990) (arguing that "Justice Blackmun may have overstated [his] point" in Bowers $v$. Harwick by comparing it to Kalz $v$. United States, "since Katz involved a type of 'privacy' that 'does make the claimant's substantive conduct irrelevant; at issue [in a case like Katz] is the government's manner of discovering the conduct'" (quoting Jed Rubenfeld, The Right to Privacy, 102 Harv. L. Rev. 737, 749 (1989)) (alteration in original)).

229. Cf. Michigan v. DeFillippo, 443 U.S. 3I, 37 (1979) (holding that evidence will not be suppressed when obtained incident to an arrest made on the basis of probable cause to believe that the individual has violated a criminal statute that is later invalidated by the Court as uncoristitutional). 
crime of homosexual sodomy. ${ }^{230}$ Public sexual relations, the discovery of which does not require searches of private places, are accordingly conceded to be outside the scope of constitutionally protected privacy. ${ }^{231}$

Under Justice Blackmun's analysis, the constitutionality of enforcement of a criminal law that necessitates searches of bedrooms for items on the order of "telltale signs of the use of contraceptives"232 should be carefully considered, because the privacy of the bedroom is at issue. It is, in other words, not possible to segregate Fourth Amendment privacy analysis completely from a substantive examination of the criminal law. A ruling for Hardwick would therefore not have amounted to the announcement of a "right" to engage in homosexual sodomy. An affirmance could have meant simply that the private space in which adults engage in consensual sexual activity must not be intruded upon without good reason (as it was intruded upon here, for example, to help ensure that homosexual sodomy does not take place). Under this reading of Griswold (and Justice Blackmun's dissent in Hardwick), the Fourth Amendment threshold to the house and bedroom ought to be a substantively heightened one.

Though this analysis of Griswold and Hardwick highlights the links between substantive and procedural "privacy" rights, it is not intended to disparage the independent legitimacy of substantive due process rights announced under a "privacy" rubric, such as the use of contraception, doctrinally distinct from a spatial privacy entitlement located within the

230. See Bowers v. Hardwick, 478 U.S. 186, 195 (1986) (noting respondent's assertion that the result ought to differ depending on whether or not the homosexual conduct occurred in the privacy of his home). But see Peter Irons, Interview with Michael Hardwick, in Lesbians, Gay Men, and the Law 125-31 (William B. Rubenstein ed., 1993) (detailing the actual facts behimd Hardwick, in which the police officer came to the respondent's home to arrest him for holding an open beer can im public, a pretext for harassment for Hardwick's sexual orientation, an orientation apparent to the pohice because Hardwick worked as a bartender in the gay bar outside of which he had been holding the open beer can).

231. It is, of course, theoretically possible for the police to discover private, consensual sodomy without performing a search or seizure (for example, by relying on a voluntary confession from one of the parties to the conduct). It is similarly possible for the police to perform a search of a private home as a means of discovering evidence of public (and therefore unprotected) homosexual sodomy (for example, by searching for fingerprints that would link the suspect to the fingerprints found at the scene of the crime). Such scenarios, however, are likely to be unusual. In the ordinary case, the private home search for evidence of sodomy would concern private rather than public acts of sodomy and might well be a necessary measure in the enforcement of a law banning such private, consensual activity. Moreover, Justice Blackmun should not be faulted for assuming that permitting criminalization of an activity would automatically also permit searches and seizures on probable cause, smce that assumption was and continues to be part of Fourth Amendment doctrine, see, e.g., Whren v. United States, 517 U.S. 806, 818 (1996) (stating that "we are aware of no primciple that would allow us to decide at what point a code of law becomes so expansive and so commonly violated that infraction itself can no longer be the ordinary measure of the lawfulness of enforcement"), albeit a part that I challenge in this Article.

232. Griswold v. Connecticut, 381 U.S. 479, 485 (1965). 
rubric of the Fourth Amendment. It might indeed be the case that there are some substantive rights that do not require physical privacy for their exercise, and that must therefore be justified, if at all, on grounds unrelated to the Fourth Amendment. The right to abortion, for example, might constitute such a right and might, for that reason, be better derived from a principle of autonomy ${ }^{233}$ and/or equality ${ }^{234}$ than from one of privacy. For much of substantive due process, however, the term "privacy" is apt because it connects a class of substantive entitlements to the spatial privacy they require. ${ }^{235}$

\section{B. Obscenity at Home}

The issue of whether to heighten the Fourth Amendment threshold to the home arose originally in Mapp v. Ohio, ${ }^{236}$ and then again in Stanley

233. See Henkin, Privacy and Autonomy, supra note 114, at 1410-11 (proposing the autonomy classification in place of "privacy" for all substantive due process entitlements).

234. See Plarined Parenthood v. Casey, 505 U.S. 833, 856 (1992) (plurality opinion) (stating that " $[t]$ he ability of women to participate equally in the economic and social life of the Nation has been facilitated by their ability to control their reproductive lives"); sec also Ruth Bader Ciinsburg, Essay, Some Thoughts On Autonomy and Equality in Relation To Roe v. Wade, 63 N.C. L. Rev. 375, 375 (1985) (proposing that the abortion right would have been better grounded in a theory of equality than one of privacy). For a provocative and compelling argument that the right to abortion stems from a basic entitlement to selfdefense against a private party causing substantial bodily harm, see Eileen L. McDonagh, Breaking the Abortion Deadlock: From Choice to Consent (1996). As Richard Parker notes, moreover, "[i]f privacy is a loss of control over by whom one can be sensed, then to be forced to go through pregnancy, childbirth, and especially raising a child is a severe loss of privacy which can last many years." Parker, supra note 52, at 290-91. Using an argument similar to McDonagh's, see supra, Parker thus links abortion privacy to Fourth Amendment privacy (though, as McDonagh points out, it is the fetus rather than the government that forces the unwanted intimacy (or the experience of being sensed without consent) at issue).

235. Richard Parker contends that "privacy defined as control over who can sense us, [is] valuable both for itself and as an empirically necessary condition for the exercise of most other rights and freedoms." Parker, supra note 52, at 290.

236. 367 U.S. 643 (1961). In Mapp, as Justice Harlan pointed out in dissent, the issue presented had been whether a criminal law banning the knowing possession or control of obscene material violated the First and Fourteenth Amendments. See id. at 672-73 (Harlan, J., dissenting) (suggesting that "the new and pivotal issue brought to the Court by this appeal is whether . . . making criminal the mere knowing possession or control of obscene material . . . is consistent with the rights of free thought and expression assured against state action by the Fourteenth Amendment"). We learn of this question in dissent rather than in the majority opinion because the Court avoided the obscenity question and instead utilized Mapp as a vehicle for announcing the application of the Fourth Amendment exclusionary rule to the states, thereby overruling Wolf v. Colorado, 338 U.S. 25 (1949). See Mapp, 367 U.S. at 646, 655. As Justice Harlan put it, "five members of this Court have simply 'reached out' to overrule Wolf." Id. at 674 (Harlan, J., dissenting); see also Stuntz, Privacy's Problem, supra note 69, at $1061 \mathrm{n} .164$ (contending that Mapp, along with several other cases, is a "free speech [] case in disgnise," noting that "Mapp was litigated in the Supreme Court as a First Amendment case" and that "[t]he crime charged-possession of obscene materials-was later invalidated on First Amendment grounds" (citations omitted)). For a gripping fictionalized account emplasizing the 
v. Georgia. ${ }^{237}$ In Stanley, the issue presented was, on its face, one regarding First Amendment freedom of speech and thought. The defendant in Stanley challenged a Georgia statute under which he was charged with the possession of obscene materials. He contended that punishing the "mere private possession of obscene matter, violates the First Amendment."238 The Court accepted Stanley's argument and held that "the mere private possession of obscene matter cannot constitutionally be made a crime." 239

Upon a closer examination of the reasoning in Stanley, it is apparent that the obscenity-possession question was never exclusively (or even primarily) about the freedom of speech. As the majority in Stanley acknowledged, "[i] $\mathrm{t}$ is true that Roth $^{240}$ does declare, seemingly without qualification, that obscenity is not protected by the First Amendment." ${ }^{241}$ The Court distinguished, however, between the prior obscenity cases (to which the opinion in Roth referred), which "deal for the most part with use of the mails to distribute objectionable material or with some form of public distribution or dissemination," 242 on the one hand, and the Stanley case, which bans the "private possession of obscene materials," 243 on the other. The distinction is between public and private, a distinction we encountered in our discussion of Justice Blackmun's Hardwick dissent. ${ }^{244}$ This distinction does not, however, normally constitute a dispositive dimension of First Amendment free speech cases, ${ }^{245}$

petitioner's racial identity along with her preference for the free speech argument in the case, see David Dante Troutt, Bitch, Son of a Bitch, in The Monkey Suit 151-95 (1998).

237. 394 U.S. 557 (1969).

238. Id. at 559 .

239. Id. Note that in reviewing a criminal statute banning the possession and viewing of child pornography, the Court came to a different conclusion, upholding the criminal ban and finding compelling the proffered interest in protecting children from exploitation and abuse. See Osborne v. Ohio, 495 U.S. 103, 108 (1990).

240. Roth v. United States, 354 U.S. 476 (1957).

241. Stanley, 394 U.S. at 560.

242. Id. at 561.

243. Id.

244. See supra notes $218-235$ and accompanying text (analyzing Bowers v. Hardwick, 478 U.S. 186, 206-08 (1986)).

245. See Lakewood v. Plain Dealer Publishing Co., 486 U.S. 750, 772 (1988) (invalidating unbridled discretion in issuing licenses in connection with public distribution of newspapers); Monitor Patriot Co. v. Roy, 401 U.S. 265, 273 (1971) (asserting that "the syllogistic manipulation of distinctions between 'private sectors' and 'public sectors' . . is of little utility in resolving questions of First Amendment protection"); Saia v. New York, 334 U.S. 558, 559-60 (1948) (holding that an ordinance requiring a permit froin the chief of police prior to using a sound amplification device was "unconstitutional on its face, for it establishes a previous restraint on the right of free speech in violation of the First Amendinent"); Thomas v. Collins, 323 U.S. 516, 539-40 (1945) (stating that "[a]s a inatter of principle a requirement of registration in order to make a public speech would seem generally incompatible with an exercise of the rights of free speech and free assembly" and "a requirement that one must register before he undertakes to make a public speech to enlist support for a lawful movement is quite incoinpatible with the requirements of the First Amendment"). 
and, if anything, militates in favor of speech concerns in public arenas. ${ }^{246}$

The anomaly of Stanley as a First Amendment case becomes especially salient later in the Court's opinion. Consider the following argument made by the majority:

It is now well established that the Constitution protects the right to receive information and ideas .... This right to receive information and ideas, regardless of their social worth . . . is fundamental to our free society. Moreover, in the context of this case-a prosecution for mere possession of printed or filmed matter in the privacy of a person's own home-that right takes on an added dimension. For also fundamental is the right to be free, except in very limited circumstances, from unwanted governmental intrusions into one's privacy. ${ }^{247}$

Obscenity is, by definition, information of little or no social worth. ${ }^{248}$ Nonetheless, the Court tells us that the individual has a First Amendment right to receive it. Unlike other information that the individual has a right to receive, ${ }^{249}$ though, the production, distribution, and dissemination of this information can be made subject to criminal penalties without violating the First Amendment. ${ }^{250}$ One would think that, at the very least, the proviclers of items that individuals have a constitutional right to receive would have third-party standing to object to laws that criminalize

246. See" United States v. Grace, 461 U.S. 171, 180 (1983) (explaining that " $[t]$ raditional public forum property occupies a special position in terms of First Amendment protection"); United States Postal Serv. v. Council of Greenburgh Civic Ass'ns, 453 U.S. 114, 130-31, 137 (1981) (explaining that the Court "has not hesitated in the past to hold invalid laws which . . . too broadly inhibited the access of persons to traditional First Amendment forums such as the public streets and parks" and that "public properties are appropriate fora for exercise of First Amendment rights").

247. Stanley, 394 U.S. at 564 (citations omitted).

248. See Miller v. California, 413 U.S. 15, 24 (1973) (holding that “[a] state offense must also be limited to works which, taken as a whole, appeal to the prurient interest in sex, which portray sexual conduct in a patently offensive way, and which, taken as a whole, do not have serious literary, artistic, political, or scientific value" (emphasis added)).

249. In the commercial speech area, for example, the First Amendment provides limited protection to speakers on the rationale that potential consumers have the right to receive the proffered information. See First Nat'l Bank of Boston v. Bellotti, 435 U.S. 765, 783 (1978) (holding that "[a] commercial advertisement is constitutionally protected not so much because i.t pertains to the seller's business as because it furthers the societal interest in the 'frec: flow of commercial information' "); Virginia State Bd. of Pharmacy v. Virginia Citizens Consumer Council, Inc., 425 U.S. 748, 764 (1976) (holding that commercial speech is protected under the First Amendment because "[e]ven an individual advertisement, though entirely 'commercial,' may be of general public interest"); see also Bigelow v. Virginia, 421 U.S. 809, 825 (1975) (holding that an abortion advertisement, because it contained information of clear public interest, was entitled to First Amendment protection); Lamont v. Postmaster General, 381 U.S. 301, 305 (1965) (invalidating, under a First Amendment right to receive information, a law that directed the Post Office to screen foreign, unsealed mail, and to detain communist propaganda with a notification to the addressee that the mail would be destroyed absent a request for delivery by the addressee).

250. See, e.g., Jacobelks v. Ohio, 378 U.S. 184, 186-87 (1964) (cited by the Court in Stanley, 394 U.S. at 560); Smith v. California, 361 U.S. 147, 152 (1959). 
their activity.251 The Court apparently fails to see any paradox, however, in protecting a right to receive that which it is a crime to provide.

The latter part of the paragraph quoted above provides a more coherent rationale for the result reached in this case. "[I]n the context of ... a prosecution for mere possession . . . in the privacy of a person's home-that right takes on an added dimension." ${ }^{252}$ It is less free speech than the "fundamental . . . right to be free, except in very limited circumstances, from unwanted governmental intrusions into one's privacy"253 that renders unconstitutional the enforcement of a law that intrudes upon the privacy of a person's home for "the mere private possession of obscene matter."254 Part of the Fourth Amendment privacy right, on this reasoning, includes limiting the types of occasions that give rise to governmental authority to search a person's home. This would mean, under a conventional approach, limiting the substantive content of the criminal law. 255

In an important sense, the Fourth Amendment right to be free from governmental personal knowledge was therefore very much at issue in Stanley. In support of this privacy argument against enforcement of the Georgia obscenity law, the Court cited Griswold.256 The Court also noted that "the States retain broad power to regulate obscenity." 257 Nonetheless, "[w] hatever may be the justifications for other statutes regulating obscenity, we do not think they reach into the privacy of one's own home."258 Such interests are not weighty enough, in other words, to justify the search of a person's home for evidence of obscenity. ${ }^{259}$ Stanley

251. Cf. Griswold v. Connecticut, 381 U.S. 479, 481 (1965) (holding that "appellants [providers of contraceptives] have standing to raise the constitutional rights of the married people with whom they had a professional relationship," because "[ $t$ ]he rights of husband and wife, pressed here, are hikely to be diluted or adversely affected unless those rights are considered in a suit involving those who have this kind of confidential relation to them").

252. Stanley, 394 U.S. at 564.

253. $1 \mathrm{~d}$.

254. Id. at 559.

255. We saw that when Hardwick was decided, Justice Blackmun thought for similar reasons that protecting the privacy of a person's bedroom from unwarranted governmental intrusion would require invalidation of a criminal statute that prohibited the mere act of private sodomy. See supra notes 220-221 and accompanying text.

256. See Stanley, 394 U.S. at 564.

257. Id. at 568 .

258. Id. at 565 .

259. Like Justice Blackmun's Hardwick dissent, the opmion in Stanley leaves ambiguous the matter of whether a person's home might be searched for evidence of obscenity production, distribution, or dissemination. This ambiguity might appropriately be left unaddressed because such evidence is normally acquired through other channels. See, e.g., Glenn Rudolph, Comment, RICO: The Predicate Offense of Obscenity, the Seizure of Adult Bookstore Assets, and the First Amendment, 15 N. Ky. L. Rev. 585, 585 (1988) (recognizing that state and local legislatures have frequently tried to himit obscenity by enacting a "variety of statutes aimed at controlling or eliminating estabhishments that disseminate sexually-exphcit materials" rather than by regulating obscenity iu the home); Jeanne Fiander, Note, A Stealthy Encroachment: Obscenity and the Fourth Amendment 
shows the obscenity problem to be less a matter of First Amendment construction than a distinctive, substantive type of Fourth Amendment question: What substantive ends justify the means of invading a person's home?

\section{Privacy Matters, Redux}

Griswold, Hardwick, and Stanley illustrate the possible connection between protecting substantive due process privacy rights (such as marital association) and protecting the private spaces of a person's life from excessive intrusion by the police. They likewise illustrate the substantive balancing that should rightfully accompany judicial consideration of law enforcement practices threatening such significant zones of private space as the house or the bedroom within it. William Stuntz identifies a related substance/process connection in his critique of the Court's exclusively procedural focus in defining the contours of constitutional criminal law. ${ }^{260}$ In his critique, Stuntz concentrates on the ways in which states may easily bypass purely procedural limitations such as probable cause, simply by expanding the scope of the criminal law. To better protect procedure, Stuntz claims, the Court would be well-advised to develop a doctrine of substantive due process that limited the scope of the criminal law. Specifically, Stuntz proposes a constitutional mens rea requirement that would preclude the enforcement of laws against people who were unaware that they were violating the law, as well as a constitutional desuetude doctrine that would prohibit the enforcement of laws that have fallen into disuse. ${ }^{261}$ According to Stuntz, such modifications in constitutional criminal law would be less radical and more appropriate than what he criticizes as the Court's Lochner-esque substantive due process "privacy" doctrine, a doctrine which he claims has little to do with privacy. ${ }^{262}$

Under Maryland $\nu$. Macon, 36 Am. U. L. Rev. 773, 773 n.2 (1987) (explaining that legislative attempts to combat obscenity have centered on zoning restrictions, nuisance statutes, and displaty legislation, all of which involve businesses rather than private homes). It is at least plausible to argue that a search of the home for evidence to solve any obscenity crime might also (and for many of the same reasons) fall within the scope of the Stanley holding.

260. See Stuntz, Givil-Criminal Line, supra note 56, at 1-2.

261. I have acivocated a related program of substantive limits on the criminal law. See Colb, Incarceration, supra note 14 , at 823 . In my proposal, however, I suggest that the criminal law be evaluated directly rather than through proxies such as ignorance of the law or desuetude, mstruments that give little guidance to police and prosecutors regarding when they may or may not enforce the law. See id. at 845-46 (agreeing with Michigan v. DeFillippo, 443 U.S. 31, 38 (1979), that "[s] ociety would be ill-served if its police officers took it upon themaselves to determine which laws are and whicl are not constitutionally entitled to enforcement," and proposing that "[e]xtending this principle to arrests for violations of laws that are ultimately held not to serve a compelling interest, the police officer involved cannot be expected (and perhaps sliould not even be allowed) to decide what governmental interests are and are not compelling").

262. See Stuntz, Civil-Criminal Line, supra note 56, at 37. 
Though well-intentioned, Stuntz's program is ultimately impractical. First, far from being a modest proposal, it is much more radical than current substantive due process doctrine. Rather than protecting specific activities, he urges the ongoing invalidation of criminal statutes that are unenforced or that people may not know exist, an ambitious project that would necessarily involve the courts in constant oversight of contemporary law enforcement practices. Second, the tail would seem to be wagging the dog in a scheme that used substantive regulation of the criminal law as an instrument for strengthening the probable cause and warrant requirements, as Stuntz suggests it should. The purpose of having such procedural requirements should be as a means of protecting substance, physical privacy, and perhaps-as I have suggested here-the right to engage in activity that appropriately falls within the rubric of substantive due process. Stuntz, however, has elsewhere rejected the legitimacy of both physical privacy ${ }^{263}$ and substantive due process privacy rights. ${ }^{264}$ It is accordingly not surprising that procedure turns out to be primary (and to drive substance) in Stuntz's program.

By contrast to Stuntz, I find it plausible to view substantive privacy rights and Fourth Amendment privacy rights as parts of one integrated whole, legitimately protected by the Constitution. For a person to be able to enjoy the exercise of her right to marry, to use birth control, and to make parental decisions regarding her children's upbringing and education, she must have a physically private space-a zone in which the government may not acquire personal knowledge of her intimate life. Conversely, in order to enjoy fully the relief from personal observation that a zone of physical (and-in our modern world-technological) privacy provides, a person might need a broad freedom to decide what to do in her private spaces, even when some of the chosen activities are themselves deemed less than fundamental (or perhaps even patently offensive) by the Court. Absent such freedom, any physical privacy might be illusory, because it would be subject to termination on the basis of suspicion regarding such a large category of activities that the requisite suspicion would become fairly easy for the government to acquire at will, rendering the zone of privacy accordingly precarious.

263. See Stuntz, Privacy's Problem, supra note 69, at 1078 (contending that "[c] riminal procedure needs reorienting," because "privacy protection as the centerpiece of criminal procedure is reactionary: it harks back to a constitutional order that placed severe limits on the size and regulatory power of the state, limits that have long since been discarded"). For further analysis of this argument, see supra notes 70-116 and accompanying text.

264. See Stuntz, Civil-Criminal Line, supra note 56, at 37 ("[T] he very thing that is most troubling about substantive due process-its unanchored quality-is an argument against extending aggressive constitutional regulation to crimmal law."). 


\section{An Improved Reasonableness BaLancing}

To the extent that the Fourth Amendment right against "unreasonable" searches contemplates a zone of spatial privacy that facilitates protected activities and that also encompasses a necessary haven from observation that is valuable in and of itself, current Fourth Amendment doctrine must change. This Article has, until this Part, articulated the direction of such change and has identified several lines of cases that have moved the law toward the recognition that change would indeed be desirable.

This Part focuses on two private spaces in which the courts have been insensitive to privacy. It argnes that, in these two spaces, a greater attention to integrating substance and procedure would have better served the privacy interesis that animate the Court's Fourth Amendment decisions. Subpart A examines a case involving a public restroom, a space where police have sonetimes conducted visual sting operations aimed at apprehending people engaged in prohibited (though consensual) sexual practices. When an individual uses the restroom, he strongly desires privacy, even in the absence of any recognized constitutionally protected activity. Subpart $A$ analyzes the clash between this desire and current privacy doctrine. Subpart B considers a space we have already discussed at some length-the home. In this Subpart, the analysis focuses on the important connection between privacy in the home and the effective protection of the right of the individual to engage in the raising of her children. Subpart $B$ argues that the law has, until now, perhaps due to a preoccupation with marital association, failed to recognize that the home is an essential locus of parental rights, regardless of a parent's marital status. ${ }^{265}$

\section{A. Using the Fourth Amendment to Guard Space}

As we saw in Griswold and Hardwick, legislation of private morality has the potential to threaten the integrity of zones of privacy such as the home or the private bedroom. Unlike in the case of crimes that have victims, the so-called "victimless" morality crimes (such as consensual sexual activity and perhaps the possession of some kinds of illicit drugs) do not typically give rise to credible witnesses who willingly cooperate with law enforcement authorities in their efforts to find the guilty parties. ${ }^{266}$

265. See generally Martha Albertson Fineman, The Neutered Mother, the Sexual Family, and Other Twentieth Century Tragedies (1995) (arguing that under current law and social understandings, the core family is the association between two monogamous sexual affiliates, and urging that this limited definition of family renders invisible the secondary dependency that derives from having to care for a child and the need of any guardian-child unil. for legal validity, financial support, and privacy from government interference).

266. As Chief ]ustice Warren explained in Lewis v. United States, “' $t$ t]here are rarely complaining witnesses [in such cases involving vice, liquor, or narcotics laws]. The participants in the crime enjoy themselves.'" 385 U.S. 206, 210 n.6 (1966) (quoting Model Penal Code $\S 2.10$ commentary at 16 (Tentative Draft No. 9, 1959)). 
As a result, perhaps, police and prosecutors investigating and prosecuting such offenses must rely heavily upon searches and seizures. ${ }^{267}$ In the case of violent, serious crimes such as murder and rape, by contrast, there are more likely to be aggrieved parties who willingly cooperate with the police and reduce the relative importance of searches and seizures.

Though there are arguably important interests at stake in limiting the proliferation of drugs, obscene materials, and some kinds of consensual sexual interactions, these interests are perhaps weakest and most vulnerable to a Fourth Amendment reasonableness challenge when they are pursued at the expense of privacy at home and privacy in the bedroom. ${ }^{268}$ As the Court stated in Stanley, the privacy threshold guarding a

267. The important role of search and seizure in the prosecution of drug and weapon possession offenses is reflected, for example, in the disproportionate number of convictions for such offenses that are reversed on Fourth Amendment grounds. See Kamisar, Comparative Reprehensibility, supra note 54, at 27 n.120, 28 (poimting out that "[a] study of suppression motions in nine mid-sized counties in three states . . found that the effects of illegal searches are concentrated in drug and weapons cases" (citing Peter F. Noardulli, The Societal Cost of the Exclusionary Rule: An Empirical Assessment, $1983 \mathrm{Am}$. B. Found. Res. J. 585, 599 Thl. 10), whereas "a recent five-year study [showed that] illegal search problems were given as the reason for the rejection of only 117 of more than 68,000 robbery arrests, only thirteen of more than 14,000 forcible rape arrests, and only eight of approximately 12,000 homicide arrests" (citing Thomas Y. Davies, A Hard Look at What We Know (and Still Need to Learn) About the 'Costs' of the Exclusionary Rule, $1983 \mathrm{Am}$. B. Found. Res. J. 611, 640, 645)); Machin, Cure Worse than Disease, supra note 53, at 43-44 (noting that "the exclusionary rule has not been responsible for the release of dangerous criminals who prey on society," but that instead, "[t] he exclusionary rule's greatest impact is felt in drug and weapons possession cases" (citing United States v. Leon, 468 U.S. 897, 907 n.6 (1984))); Steven Yarosh, Comment, Operation Clean Sweep: Is the Chicago Housing Authority 'Sweeping' Away the Fourth Amendment?, 86 Nw. U. L. Rev. 1103, 1128 n.184 (1992) (observing that " "[f] ewer than $1 \%$ of Chicago defendants accused of violent crimes have their cases thrown out because the evidence was illegally obtained," that "[t]he exclusionary rule plays a signiflcant role only in drug cases where violence is not involved," and that "[t] he rule has httle impact on other kinds of cases" (quoting Joseph Tybor \& Mark Eissman, Illegal Evidence Destroys Few Cases: Justice in Chicago, Chi. Trib., Jan. 5, 1986, at 1)).

268. Of course, the home and the bedroom should not provide a refuge of privacy for the commission of marital assaults, child-abuse, or forced sexual relations. See supra notes 212-217 and accompanying text (analyzing Justice Douglas's opinion in Griswold and distinguishing between a search for evidence of contraceptive use, on the one hand, and evidence of a violent crime, on the other). It is critical that the law not embrace, in the name of privacy in the home, the sort of "hands-off" policy toward domestic violence that characterized it up to and including the early part of this century. See, e.g., Reva B. Siegel, "The Rtule of Love": Wife Beating as Prerogative and Privacy, 105 Yale L.J. 2117 (1996); Model Penal Code $§ 213.1$ (1962) (imposing criminal liability for rape only upon "[a] male who has sexual intercourse with a female not his wife") (emphasis added). The comments accompanying the Model Penal Code section rely upon notions of "family privacy" to justify the retention of the marital rape exemption to "situation[s] of rape by force or threat." See Model Penal Code $\$ 213.1 \mathrm{cmt}$. 8(c), at 345 (1962) (asserting that "[r]etaining the spousal exclusion avoids this unwarranted intrusion of the penal law into the life of the family"). Such an approach appears to pervert the notion of privacy rights into a license to harm and threaten the safety of one rights-possessing individual (a wife) in the name of another's (a husband's) security from unreasonable searcli and seizure. 
person's home should be high enough to block the government from investigating violations of criminal prohibitions otherwise appropriate and legitimately enforced in public. Though the Court has held that the Constitution protects "people, not places," 269 the people's privacy might require greater protection in some places, such as the home or the bedroom, than in others, such as the open field. ${ }^{270}$

Beyond the home and the private bedroom, there are other spaces in which the aggressive enforcement of morals legislation has a similar potential to jeopardize a true freedom from observation. The public telephone is one such "area." 271 Another is the public restroom. Adults (and some children) who take advantage of the availability of public restrooms in parks, train stations, or various other locations, generally prefer to use a closed, private stall, in order to remain alone and unobserved while using the toilet. Young children tend to understand the private nature of toilet functions and (much to their parents' embarrassment) often joke about such functions with one another.

The desire for bathroom solitude would not appear to implicate what we earlier called informational privacy, of the sort that Stuntz described as the very definition of doctrinal Fourth Amendment privacy and, accordingly, disparaged. ${ }^{272}$ Using the bathroom is not a mysterious, informationally "secret" act in which only some but not others engage. We have therefore not learned much information about a specific individual after having observed him while he is so engaged. Nonetheless, we have, in such a scenario, acquired "personal knowledge" of the individual in a way that both viewer and viewee are likely to find quite awkward and uncomfortable. This discomfort is evident, for instance, in situations in which a bathrocm stall door does not lock securely, and an unsuspecting third person opens it while the stall is in use. The occupant typically slams the door shut while the intruder looks away and perhaps mutters a flustered apology.

On this issue of bathroom privacy, consider a Fourth Amendment case from the Ninth Circuit Court of Appeals, Smayda v. United States. 273 In this case, Joseph Smayda and Wendell Gunther appealed convictions in connection with their violation of the Assimilative Crimes Act, ${ }^{274}$ which incorporates the state criminal statutes of the jurisdictions in which fed-

269. Katz v. United States, 389 U.S. 347, 351 (1967) (holding that "the Fourth Amendment protecrs people, not places").

270. See id. at 360 (Harlan, J., concurring) (conceptualizing the Court as holding that "an enclosed telephone booth is an area where, like a home ... and unlike a field, ... a person has a constitutionally protected reasonable expectation of privacy"); Oliver v. United States, 466 U.S. 170, 184 (1984) (finding no "reasonable expectation of privacy" in "open fields").

271. See Katz, 389 U.S. at 360 (Harlan, J., concurring).

272. See supra Part 1.C (discussing Stuntz's arguments defining and devaluing the supposed Fourth Amendment privacy from disclosure of secrets).

273. 352 F.2d 251 (9th Cir. 1965).

274. See id. at 251 (citing 18 U.S.C. $\$ 13$ ). 
eral enclaves (such as national parks) are located. In Smayda, the petitioners were convicted of engaging in oral copulation with each other through a hole carved between two stalls within a restroom in Yosemite National Park, in violation of California law.275 Police, having had reason to believe that such sexual acts were occurring in the restroom, arranged for a hole to be cut in the ceiling over each stall, "for purposes of observation."276 The hole was covered with a screen "so as to make it look like an air vent." 277 In the course of the investigation to root out offenders,

[s] ome 25 or 30 persons were observed who simply made the normal use of the stall. Others were seen who peered through holes in the partitions, looked at each other over the partitions, masturbated, and at least two of whom performed an indecent act through the hole in the partition, but not in violation of P.C. section $288 \mathrm{a}$. No arrests were made. ${ }^{278}$

On another night of toilet surveillance, after "[s]ix or seven persons whose behavior was normal were observed," the police spotted petitioners violating the statute and arrested them. ${ }^{279}$ Though "there was reason to believe that someone might commit the offense that evening, there was no reason to believe, at any time until after each appellant entered a stall, that that particular person was about to commit it." 280 The police therefore lacked individualized suspicion prior to any individual bathroom viewing. The Court of Appeals held that there was still no Fourth Amendment violation, reasoning that "when people resort to such a public toilet for criminal purposes, they deliberately take the chance that they may be observed by police officers, and that they are not protected from such observation"281 - a waiver argument. The court added that, alternatively, no search had occurred, because "these stalls were, in essence, a public place." 282

Neither of these alternative theories is persuasive. "Guilty" parties may, from their own perspectives, waive any right to have their guilty behavior remain private. ${ }^{283}$ That waiver, however, was not communicated in Smayda to the relevant state actors until after the observation had taken place. Therefore, the waiver theory here does not justify the officers' conduct with respect to the petitioners. The many innocent users of the restroom, moreover, necessarily retained their Fourth Amendment rights, and the cost of apprehending the guilty here was the search of more than

275. See id. at 252.

276. Id.

277. Id.

278. Id. at 253.

279. Id.

280. Id.

281. Id. at 254 .

282. Id. at 255.

283. See Colb, Innocence, supra note 9, at 1501 (discussing how, "[b]y abusing [one's] private space through illegal activity and concealment of evidence . . . one forfeits one's Fourth Amendment privacy interest" in that particular space). 
30 innocent people who had in no way waived their privacy entitlements. ${ }^{284}$ The Court of Appeals's alternative theory-that the inside of a toilet stall in a public bathroom is a public place where occupants cannot expect to be protected from observation-seems to contradict the common expectaticn of what the court calls the "normal" user of the bathroom. People who choose to make use of a public restroom and to close their stall doors (so that police who wish to observe must conduct surveillance from a hole in the ceiling and conceal their presence with a deceptive screen) actually-and legitimately-expect to be free from observation.

As the Court of Appeals suggested, it might be that the only way to catch people engaged in the criminal activity implicated in Smayda is to place under surveillance the restroom stalls in which such activity is suspected to occur. ${ }^{285}$ There would rarely arise individualized suspicion with respect to any specific persons who might use the bathroom. To discover offenders, the suspicion that attaches to the particular stall (at a particular time, on a particular night of the week) would have to suffice. As in Griswold, the vitality of the criminal law at stake in Smayda was intimately linked with the Fourth Amendment legality of effective law enforcement techniques. Just as apprehending people violating contraception prohibitions would require searches of marital bedrooms for telltale signs of contraceptive use, so apprehending people violating the prohibitions at issue in Smayda might require "clandestine surveillance by police" of all persons using suspected toilet stalls over a period of time. ${ }^{286}$ On a Fourth Amendment analysis that does not consider the gravity of the offense at issue, the necessity of such tactics might well signal their "reasonableness." The Supreme Court has, on similar grounds, refused to hold warrantless undercover operations to be unreasonable under the Fourth Amendment. 287 Under a qualitative analysis that includes a critical con-

284. See id. at 1480 (discussing the overbreadth theory of the exclusionary rule and contending that "there is an affirmative case . . . for allowing the guilty to litigate Fourth Amendment violations, in spite of the undeserving character of such individuals" to protect the rights of innocent parties who could be damaged by illegal police searches but who would be unlikely to initiate litigation); see also State v. Bryant, 177 N.W.2d 800, 801 (Minn. 1970) (noting in a related context that the "[a] uthority of police officers to spy on occupants of toilet booths-whether in an amusement park or a private home-will not be sustained on the theory that if they watch enough people long enough some malum prohibitum acts will eventually be discovered" " (quoting Bielicki v. Superior Court, 371 P.2d 288, 292 (Cal. 1962))).

285. See Smayaia, 352 F.2d at 254.

286. Id.

287. See, e.g., Lewis v. United States, 385 U.S. 206, 210 n.6 (1966) (explaining that "in the enforcement of vice, liquor or narcotics laws, it is all but impossible to obtain evidence for prosecution save by the use of decoys. There are rarely complaining witnesses. The participants in the crime enjoy themselves." (quoting Model Penal Code $\$ 2.10$ commentary at 16 (Tentative Draft No. 9, 1959))); see also Bryant, 177 N.W.2d at 805 (Otis, J., dissenting) (arguing on facts very similar to those in Smayda that the Minnesota Supreme Court majority opinion erred in suppressing evidence based upon police 
sideration of both the invasiveness of enforcing a law effectively and the significance of the legislation, however, the legitimacy of a law necessitating such intrusive surveillance would present an issue extending beyond the usual substantive due process question of whether there is a fundamental right to engage in the prohibited activity. ${ }^{288}$ In Griswold, for example, the Supreme Court took the latter approach and struck down a ban on contraceptive use. ${ }^{289}$ In Smayda, although a fundamental right to engage in sexual activities in public toilets is unlikely to exist, the apprehension of those who do so engage might simply not be an important enough objective to justify the surveillance of adult human defecation. ${ }^{290}$

surveillance in a department store bathroom because, "[s]ince it would never be possible to secure a search warrant in situations of this kind, I am of the opinion this surveillance for a limited time and purpose was reasonable and did not violate the Fourth Amendment").

Although the exclusion of undercover surveillance activity from the category of "searches" subject to Fourth Amendment regulation is doctrinally distinct from a holding that searching an occupied restroom stall is "reasonable," the distinction does little to constrain the Court's approval of investigation that proceeds in the absence of individualized suspicion. As we see in Lewis, for example, exclusion of undercover operations from the definition of "search" can turn on a factor such as the impossibility of enforcing narcotics laws without undercover operations-a consideration that is usually not especially pertinent in answering the question whether a person might reasonably expect privacy from the government in a given set of circumstances. In Smayda itself, the Court of Appeals argued (as one alternative rationale for its decision) that there is no reasonable expectation of freedom from observation in a "public" restroom. See Smayda, $352 \mathrm{~F} .2 \mathrm{~d}$ at 255 . The occupant of the restroom stall is unlikely to derive much comfort from learning that the police who watched him use the toilet were not engaged in a "search."

The court's first argument in Smayda-that anyone using the restroom in the way that petitioners did waives any interest in privacy-also has an analogue in the precedents governing undercover operations. In United States v. White, 401 U.S. 745 (1971) (plurality opinion), which upheld simultaneous transmission of a suspect's words by an undercover informant to the police, Justice White's opinion for a plurality asserted that

[i]nescapably, one contemplating illegal activities must realize and risk that his companions may be reporting to the police. If he sufficiently doubts their trustworthiness, the association will very probably end or never materialize. But if he has no doubts, or allays them, or risks what doubt he has, the risk is his.

Id. at 752. This waiver argument is necessarily as flawed in the undercover context, see Colb, Innocence, supra note 9, at 1511-12, as it is in the "public restroom" context. See supra notes 282-284 and accompanying text.

288. Cf. Colb, Incarceration, supra note 14 , at 805 n.97 (explaining that " $[t]$ he fourteenth and fifth amendment right to liberty from confinement . . . constrains the means by which the government may pursue an otherwise allowable end that does not inherently implicate a fundamental right"); id. at 789 (arguing from the civil commitment context that " $[\mathrm{i}] \mathrm{n}$ order to justify [the deprivation of a person's physical liberty], . . . the state must have a stronger interest necessitating that confinement than the merely 'legitimate' interest in improving the citizens' comfort level," and that "[ $t]$ he state needs an interest as strong as that present when the relevant individual poses a danger to herself or to others").

289. Griswold v. Connecticut, 38I U.S. 479, 485-86 (1965).

290. One distinction between the respective facts of Griswold and Smayda is that searches for contraceptive use held unconstitutional in Griswold would presumably proceed 
The public restroom is a useful area for our consideration, because it helps us to disaggregate the need for privacy-from-observation as an end in itself, on the one hand, and the need for privacy from observation as a means of effectuating substantive due process privacy rights, on the other. By contrast to the home, the public toilet is not an important location for effectuating fundamental rights. ${ }^{291}$ We do not, as a society, expect or wish for people to express themselves sexually in the public restroom. If we did, then bathrooms would generally be unisex (thereby facilitating, for example, the protected heterosexual married couple's access to each other). In spite of its relative unimportance as a locus of fundamental rights, however, people nonetheless value privacy from observation in the restroom. ${ }^{292}$ I suggest that we incorporate this sort of

upon individualized suspicion. No party, in other words, took the position that police ought to be able to conduct bedroom surveillance of every married couple as a means of enforcing the ban on contraceptive use. In Smayda, by contrast, part of what may lead us to reject as unreasonable the surveillance at issue is that it encoinpassed every user of the stalls during a given time-frame, without individualized suspicion attacbing to any specific individual. Perhaps if the police had had probable cause to believe that a particular set of individuals would be inisusing the stalls, and they watched only those individuals, the reader might view the Fourth Amendment claim as substantially less compelling. Even on this analysis, however, it would still be appropriate to perform a substantive balancing between the privacy rigbts at stake (taking into account the interests of those innocent people likely to be swept within a inore or less imprecise surveillance) and the competing governmental interest in preventing the sexual use of the public bathroom. Furthermore, if the sort of surveillance conducted in Smayda were determined to be the only way to enforce the relevant criminal prohibition, the Court would face a dilemma very much like those it faced in the cases allowing nonsuspicion-based "false-friends" to solicit, record, and transmit the words of a suspect. The Court would have to decide between the formalistic approacb taken in Smayda and Lewis, in which a necessary enforcement tool is ipso facto constitutionally permissible, and the more subtle, sensitive, and integrated approach taken in cases such as Griiwold, Garner, and Justice Blackmun's dissent in Hardwick.

291. But see Taunya Lovell Banks, Toilets as a Feminist Issue: A Trne Story, 6 Berkeley Women's 1.J. 263 (1990-1991) (contending that access to restrooms is essential to full and equal participation in public life and that the differential denial of such access to women has represented an important barrier to women's full equality); Sheryl Gay Stolberg, Gay Culture Weighs Sense and Sexuality, N.Y. Times, Nov. 23, 1997, § 4 (Week in Review), at 1 (discussing controversy in the gay community over the importance of promiscuity and the perceived backlash of police crackdowns on sex in public restrooms, gay discos, and pubs).

292. Indeed, soine people bave reacted with outrage at the prospect of the "Hygiene Guard," a recently developed device that monitors whether individuals who enter the restroom wash their hands before leaving. See Robert O'Harrow, Jr., Big Brother In Workplace Bathrooms?, Wash. Post, Aug. 30, 1997, at Al (describing the monitoring systeln and noting that "privacy advocates complain Hygiene Guard represents an unprecedented intrusion" and that "[c]ivil libertarians described Hygiene Guard as "Big Brother in the bathroom" "). The objective, to ensure that employees do not circulate fecal bacteria to others at the workplace, would seem to many people stronger than that at issue in Smayda, and the Flygiene Guard certainly intrudes far less on the personal privacy of the restroom user than did the surveillance in Smayda. This suggests that when it comes to the privacy of toilet use, people are highly sensitive even to relatively minor investigative measures and would be especially upset to learn that they had been observed by police while enclosed in their stalls. 
value into the meaning of Fourth Amendment "reasonableness" when we evaluate the legitimacy of law enforcement practices employed to facilitate the apprehension of those who are engaged in a broad range of offenses occurring in such private spaces.

\section{B. Using the Fourth Amendment to Guard Substantive Due Process}

We saw in our discussion of Smayda, and in the Supreme Court's warrant requirement jurisprudence of Payton, Steagald, and Welsh, that heightening the threshold of allowable intrusion into designated private spaces helps to protect zones of privacy that would otherwise be vulnerable to legislative prerogative. ${ }^{293}$ We have also seen that some private places, such as the home or bedroom, might additionally constitute critical zones for the exercise of substantive due process privacy rights, including marital association and procreation. The Court implicitly recognized the link between private spaces and substantive due process privacy in Griswold, the decision protecting the use of contraceptives by married couples. The Court might similarly see fit to acknowledge that link more generally in approaching the analysis of enforcement of criminal laws through home searches.

One area that would benefit from the integration of quantitative and qualitative reasonableness assessments involves welfare benefits for families with dependent children. By "welfare," I mean the provision by the government of such necessaries as food, shelter, and medical care for indigent families. The last few years have seen an increasingly punitive political discourse about the need to tie receipt of welfare benefits to conditions by which a recipient might enhance, reduce, or eliminate her welfare eligibility by acting in socially "responsible" or "irresponsible" ways. ${ }^{294}$ One component of the legal program that this discourse has helped to generate attempts to encourage welfare mothers to avoid having any more children, ${ }^{295}$ and to conduct themselves generally in a man-

293. See supra notes 138-168 and accompanying text (discussing Payton v. New York, 445 U.S. 573, 602-03 (1980); Steagald v. United States, 451 U.S. 204, 222 (1981); Welsh v. Wisconsin, 466 U.S. 740 (1984)).

294. See, e.g., Linda C. McClain, "Irresponsible" Reproduction, 47 Hastings L.J. 339, 341 (1996) (explainimg how "[i]n the recent debates over welfare reform, lawmakers and others made repeated appeals for legislative change that would end 'illegitimacy,' restore personal responsibility, and get people (women and adolescent females) to stop having children that they cannot afford to support without public assistance").

295. Many states, for example, have limited welfare benefits to support of a specified number of cliildren and no more. See Ariz. Rev. Stat. Ann. $\$ 46-292(c)(1)$, (f) (West 1997); Cal. Welf. \& Inst. Code \$ 11450.04(a) (West Supp. 1998); Ga. Code Ann. \$ 49-4-186 (1998); N.J. Stat. Ann. § 44:10-61(a) (West Supp. 1998); Okla. Stat. Ann. tit. 56, § 230.58 (West Supp. 1998); Va. Code Ann. \$ 63.1-133.48 (Michie 1995); see also Del. Code Ann. tit. 31, $\$ 501$ (1997) (policy statement discouraging welfare recipients from having children while receiving benefits); Miss. Code Ann. $\$ \$ 43-17-1$ (4) (c), 43-17-35(1) (a) (Supp. 1998) (same). 
ner that meets the approval of a supervising social agency. ${ }^{296}$ Though the intensity of these measures might be new, the question of government control over the lives of welfare recipients has been with us for some time.

In Wyman $\%$ James, 297 the Supreme Court held that discontinuing the welfare benefits (AFDC) of a woman for her refusal to consent to a social worker's home visit did not violate the woman's Fourth Amendment privacy rights. First, the Court took the position that a home visit by a social worker is not a "search" within the meaning of the Fourth Amendment. The Court reasoned that home visits are not conducted primarily for the investigative reasons that have traditionally defined searches in the criminal law context. ${ }^{298}$ Moreover, as the Court elaborated, women could refuse consent to the home visit (as Mrs. James did in this case), so that there would be no actual search to violate (or even implicate) the Fourth Amendment in the case of such refusals. ${ }^{299}$ The Court argued in the

296. At least three states permit regular supervision of welfare recipients to assure compliance with state regulations. See 305 Ill. Comp. Stat. Ann. 5/4-6 (West 1993); Me. Rev. Stat. Ann. tit. 22, § 3763(5) (West Supp. 1997); S.D. Admin. R. 67:12:01:05 (1997). Most states allow an initial home visit to verify applications for welfare benefits. See, e.g., Cal. Welf. \& Inst. Code $\$ 11265$ (c) (West 1991). Most recently, Mayor Rudolph W. Giuliani of New York City instituted a pilot project in which people seeking Medicaid are subjected to a home: investigation very much like the one at issue in Wyman v. James. In one case, an immigrant froin Ecuador applied for Medicaid health insurance benefits for her two-year-old son and provided the documentation evidencing lis eligibility. In inspecting her home, two city investigators "walked into her bedroom, peered into her closet and spotted the evidence they later used to recommend rejection: a pair of blue jeans-men's jeans, they insisted--hanging among her dresses." The Mayor apparently plans to expand the pilot program to the entire city next year. Nina Bernstein, New Hurdle for Some Seeking Medicaid: Home Inspections, N.Y. Times, Sept. 20, 1998, at 43.

297. 400 U.S. 309 (1971).

298. See id. at $317-18$.

299. See id. This argument, that if there was no search (because a complainant refused consent and accordingly suffered the loss of a benefit), there can be no Fourth Amendment violation, mirrors an argument made by Justice Blackmun in his dissent from New Jersey v. Portash, 440 U.S. 450 (1979). Justice Blackmun argued there that the defendant did not have a ripe Fifth Amendment claim, since the defendant had not testified after the judge at his criminal trial ruled in a motion in limine that if the defendant were to testify, his testimony could be impeaclied with compelled selfincrimmating staternents given under a grant of immunity. See 440 U.S. at 464-65. This justiciability argument, both in Portash and in James, iguores the problematic nature of threats that might chill the exercise of constitutionally protected rights, whether the right to exclude compelled, self-incriminating statements at one's criminal trial (without having to refrain from testifying), or the right to enjoy privacy from governmental intrusion (without having to give up eligibility for AFDC benefits) is at issue. A related argument would permit the government to condition a benefit to which there is no constitutional entitlement upon the waiver of a constitutional right, on the theory that the beneficiary need only refuse the benefit to which she has no preexisting entitlement in order to preserve her constitutional rights intact. This argument lias been met with strong criticism by scholars of constitutional law. See Kathleen M. Sullivan, Unconstitutional Conditions, 102 Harv. L. Rev. 1413 (1989) (proposing an analytic framework for a robust protection against "unconstitutional conditions" under which people must waive constitutional 
alternative that even if there were stipulated to have been a Fourth Amendment search, the search would have been reasonable because its objective-the child's welfare-constituted an unassailable, compelling purpose. Notice that this alternative argument does not rest upon the assumption that welfare is not an entitlement and that it is therefore legitimate for the receipt of welfare to be conditioned upon the waiver of Fourth Amendment rights. ${ }^{300}$ The second argument instead takes seriously the privacy deprivation suffered by welfare recipients and engages in a balancing of the cost of home visits to the mother's privacy against the benefit of such visits to the child's security.

In forming a reaction to the Court's second argument, a number of points in the James opinion are particularly noteworthy. First, the Court declared the importance of privacy in the home, specifically focusing upon the siguificance of being able to exclude unwanted intruders for the individual's sense of security. The Court explained:

When a case involves a home and some type of official intrusion into that home, as this case appears to do, an immediate and natural reaction is one of concern about Fourth Amendment rights and the protection which that Amendment is intended to afford. Its emphasis indeed is upon one of the most precious aspects of personal security in the home: "The right of the people to be secure in their persons, houses, papers, and effects."

After acknowledging the import of the right that respondent pressed, the Court denied her claim by relying heavily on the very strong public interest in protecting the welfare of children and in preventing their exploitation. In his opinion for the Court, Justice Blackmun stated:

The focus is on the child and, further, it is on the child who is dependent. There is no more worthy object of the public's concern. The dependent child's needs are paramount, and only with hesitancy would we relegate those needs, in the scale of

entitlements to gain access to government benefits); Cass $R$. Sunstein, Why the Unconstitutional Conditions Doctrine Is an Anachronism (With Particular Reference to Religion, Speech, and Abortion), 70 B.U. L. Rev. 593 (1990) (contending that in the modern regulatory state, where government can routinely affect the exercise of constitutional rights by funding and subsidy decisions, an unconstitutional conditions doctrine premised on the pre-New Deal assumption that government funding is exceptional, will not meaningfully protect the exercise of constitutional rights). As a policy matter, the imposition of such conditions on receipt of government benefits ignores the coercive circumstances under which an individual makes the "choice" to give up the exercise of a protected right. Cf. Slobogin, supra note 12, at 96-97 (criticizing the waiver argument in the context of employees who are subjected to governmental inspections, arguing that "[a] surprise inspection is not made less offensive because its victim has, in effect, been forced to consent to it in advance").

300. For a more detailed analysis of the conditioning of government benefits upon the waiver of constitutional rights, see Dorothy E. Roberts, The Only Good Poor Woman: Unconstitutional Conditions and Welfare, 72 Denv. U. L. Rev. 931 (1995).

301. James, 400 U.S. at 316. 
comparative values, to a position secondary to what the mother claims as her rights. ${ }^{302}$

The Justices seem to have conceptualized the case before them as presenting a conflict between the needs of a child and the claims of the child's mother regarding her own rights.

The Court has not consistently characterized parents, the way that it does here, as adversaries of their children when the parents have claimed a protected liberty. Such an adversarial structure implicitly adopts the premise that parents cannot be trusted to act in their children's best interests. By contrast, in Wisconsin v. Yoder, ${ }^{303}$ the Court emphasized the Amish parents' rights, as parents and as adherents of the Amish faith, to shape the upbringing of their children in a way that was allegedly undermined by Wisconsin's educational requirements. The Court in Yoder did not see the home-education claims of the Amish parents as a threat to their children's access to a free, pluralistic education. The Court might have legitimately viewed the case in such a manner, of course, because the parents defended their home-education claims precisely on the basis of an alleged interest in insulating their children from exposure to ideas different from those espoused by the parents' Amish faith. ${ }^{304}$ The Court, however, deferred in Yoder to the Amish parents and proceeded on the assumption that absent substantial evidence to the contrary, parents are best situated to make decisions about their children's upbringing, even when their decisions deny children access to state-provided benefits such as school education beyond the eighth grade.

We might infer from a juxtaposition of James and Yoder that the Court distinguishes between parents who are dependent on government assistance (the poor) and those who are not. It would appear that the Court believes that the former group is not entitled to the same presumption of good faith as the latter. As Justice Marshall noted in dissent in James:

These [the child abuse and exploitation that might go undiscovered absent the challenged home visit] are heinous crimes, ${ }^{305}$ but they are not confined to indigent households. Would the majority sanction, in the absence of probable cause, compulsory visits to all American homes for the purpose of discovering child

302. Id. at 313.

303. 406 U.S. 205 (1972).

304. Indeed, Justice Douglas made exactly this argument in his dissenting opinion. See id. at 245-46 (Douglas, J., dissenting) (arguing that a child's "entire life may be stunted and deforned" if her education is truncated based solely on her parents' wishes).

305. Though the statutory rationale of home visits may have been primarily the determination of continuing welfare eligibility, see James, 400 U.S. at 311 n.2 (quoting the statute under challenge describing the home visit condition as intended to make sure "that assistance or care may be given only in such amount and as long as necessary") (citations omitted), both majority and dissenting opinions focus their analysis on a distinct and more compelhing rationale-the safety of children. It is this latter rationale that accordingly drives discussion of the case in this Article. 
abuse? Or is this Court prepared to hold as a matter of constitutional law that a mother, merely because she is poor, is substantially more likely to injure or exploit her children? Such a categorical approach to an entire class of citizens would be dangerously at odds with the tenets of our democracy. ${ }^{306}$

It is likely that the Court would respond to Justice Marshall's accusations by rejecting the premise that Mrs. James had a real Fourth Amendment interest at stake. Instead, the Court might explain, the decision does not reflect any negative judgment about the indigent but merely affirms the government's authority to decide how to spend its money. The Court has accordingly upheld other conditional spending decisions by the government that had the effect of burdening various constitutional rights. ${ }^{307}$ Because the Court addressed its second argument in James in terms of the Fourth Amendment and privacy, however, and thereby put to one side the "consent" issue for purposes of argument, it is appropriate for Justice Marshall and for us to analyze the decision critically, in terms of its impact on the privacy rights of parents. This impact, moreover, might logically and legally extend not only to parents receiving welfare benefits, but to parents more generally, because tax exemptions for dependents, to which all taxpayers with dependent children

306. James, 400 U.S. at 342 (Marshall, J., dissenting). But see Leroy H. Pelton, The Role of Material Factors in Child Abuse and Neglect, in Protecting Children from Abuse and Neglect: Foundations for a New National Strategy 131 (Gary B. Melton \& Frank D. Barry eds., 1994) (noting a strong correlation between poverty and the incidence of child abuse). Pelton explains:

[S]ince AFDC status is merely an indicator of poverty, $40-50 \%$ of all child abuse and neglect incidents occur within families receiving AFDC at the time of the incident, and the great majority of families mvolved in such incidents have been on AFDC at some time. For similar reasons, counties with the highest rates of food stamp recipients are also the counties with the highest incidence rates of child abuse and neglect.

Id. at 167. Regardless of whether poverty correlates with child abuse and neglect, however, a family's poverty is unlikely to provide as reliable a predictor of abuse as complaints (by the child himself, neighbors, teachers, or the child's peers) about suspected abuse in particular homes.

An alternative account of the distinction between James and Yoder might be that the Amish families in Yoder may have consisted of two-parent groupings, while the petitioner in James was a smgle mother. Cf. Martha Albertson Fineman, The Neutered Mother, the Sexual Family, and Other Twentieth Century Tragedies 177-93 (1995) (arguing that single mothers and their children are denied privacy rights afforded to families that conform to traditional notions of the nuclear family).

307. See, e.g., Rust v. Sullivan, 500 U.S. 173, 203 (1991) (upholding the constitutionality of federal regulations which prohibit health care professionals from engaging in abortion counseling under any project funded by Title $\mathrm{X}$ of the Public Health Service Act); Harris v. McRae, 448 U.S. 297, 317-18 (1980) (upholding the constitutionality of the Hyde Amendinent which severely limits the federal funding of abortions); Maher v. Roe, 432 U.S. 464,480 (1977) (holding that the Equal Protection Clause of the Fourteenth Amendment did not require that a state participating in the Medicaid program pay for nontherapeutic abortions). 
are entitled, count as government subsidies that might therefore be subject to conditional funding precedents. ${ }^{308}$

In criticizing James, it would certainly be unfair to accuse the Court of failing to perform substantive reasonableness balancing. The Court specifically emphasized the compelling nature of a child's safety needs, in overriding the competing interests of the mother. Indeed, recent news reports of child abuse and child murder by parents and custodians might suggest to many that the government ought to become tougher rather than more lenient in carrying out its enforcement of child welfare legislation. ${ }^{309}$ The problem with the Court's approach in James was that the constitutional analysis was exclusively substantive and therefore contained no quantitative measure of how likely a specific welfare parent was to be engaged in abuse, neglect, or fraud. ${ }^{310}$ The Court thus required no indi-

308. For the proposition that a tax deduction qualifies as a government subsidy for purposes of the Fourteenth Amendment, see Regan v. Taxation With Representation, 461 U.S. 540, 550-51 (1983) (upholding government decision not to subsidize, through the deductibility of contributions, those organizations engaging in political lobbying); cf. Bob Jones University v. United States, 461 U.S. 574, 599 n.24 (1983) (leaving open the question of whether the equal protection component of the Fifth Amendment requires the denial of tax-exempt status to racially discriminatory schools).

309. The failure of state social workers to maintain competent protective services has received increased scrutiny in recent years. See, e.g., Vivian S. Toy, Public Advocate Faults Child Welfare Agency in the Deaths of 15, N.Y. Times, Nov. 20, 1997, at B3 (quoting the New York City Public Advocate's conclusion that "[ $t$ ] he city is still failing to adequately protect the most vulnerable children from the most horrible tragedies" after the 1995 death of Elisa Izquierdo); see also Another Preventable Death, N.Y. Times, Nov. 12, 1997, at A30; David L. Lewis, Child Deaths Probed: Suspicious Cases Up a Third in the City, N.Y. Daily News, Jan. 16, 1998, at 8; Katherine Shaver, Md. Man Pleads Guilty in Death of Daughter: Child J)ied 3 Months after First Abuse Reports, Wash. Post, Jan. 31, 1998, at B1; Rachel L. Swarns, Boy Who Died Had Shown Earlier Signs of Abuse, N.Y. Times, Apr. 1, 1997, at B1; Rachel L. Swarns, Weeks Before Baby's Death, Bruises Gave Sign of Trouble, N.Y. Times, Dec. 2, 1997, at B3; Jim Yardley, Neighbors and Officials Blind to Neglected Girl, N.Y. Times, Dec. 14, 1997, at 51.

310. In faulting the James Court for its failure to require some quantitative measure of mdividualized suspicion, I do not mean to suggest that suspicionless searches are never appropriate. For example, inspections of industrial workplaces in the interests of health and safety pose hitle threat to personal privacy. See, e.g., Donovan v. Dewey, 452 U.S. 594, 596 (1981) (uphclding warrantless mine safety inspections conducted under the Federal Mine Safety and Health Act). In Dewey, the Court explained that:

The greater latitude to conduct warrantless inspections of commercial property reflects the fact that the expectation of privacy that the owner of commercial property enjoys in such property differs significantly from the sanctity accorded an individual's home, and that this privacy interest may, in certain circumstances, be adequately protected by regulatory schemes authorizing warrantless inspections.

Id. at 598-99; see also United States v. Biswell, 406 U.S. 311 (1972) (upholding warrantless inspection of hcensed gun dealer's store-room). The Court in Dewey distinguishes Marshall v. Barlow's, Inc., 436 U.S. 307 (1978), a decision invalidating an inspection provision of the Occupational Health and Safety Act, emphasizing the unbridled discretion of inspectors who carry out the searches. See Dewey, 452 U.S. at 603; cf. Colb, Innocence, supra note 9, at 1488 (noting, in the context of identifying the targeting harm in Delaware $v$. Prouse, that '[ $t$ ] he Fourth Amendment . . . requires either 'less intrusion' (in terms of the substantive 
vidualized suspicion element to assure that the admittedly compelling interest in protecting children would in fact be implicated when a particular social worker conducted a visit to a particular welfare family's home. The consequence of this omission was that even as innocent parents might be searched in large numbers by virtue of their receipt of government assistance, child-welfare agencies would simultaneously devote fewer of their limited resources to focusing investigative efforts upon the individuals against whom complaints had already been made and as to whom there could, therefore, be real dangers in government neglect. In other words, targeting indigent families is not only unfair to these families, but it is also an imprecise means of promoting child safety.

The difficulty with James was thus the reverse of what we typically see in the Court's Fourth Amendment precedents. Just as we saw earlier that the probable cause and warrant requirements could not effectively guarantee privacy without substantive Fourth Amendment standards, James teaches that the requirement of a compelling or otherwise substantial governmental interest supporting an intrusion also cannot guarantee a meaningful level of privacy in the absence of quantitative measures that fairly limit investigation to an appropriate subset of the population. ${ }^{311}$

In addition to exposing many families to a gratuitous invasion of privacy, the failure of the Court to coordinate quantitative and qualitative scrutiny under the Fourth Amendment perpetrates a targeting harm. In this case, the government official does not select the target. Instead, the welfare legislation at issue selects the target of the intrusion: those individuals who rely upon a specific kind of government benefit-one associated with poverty. Only such individuals will be subject to the indignity of home visits. ${ }^{312}$ The targeting harm thus originates here in an authority to search a particular category of individuals many of whose members have

seizure harm) "or [methods] that do not involve the unconstrained exercise of discretion" (citations omitted)).

311. In a similar vein, Christopher Slobogin has ably described the Fourth Amendment analysis that might accompany the proposed use of torture to learn the whereabouts of a nuclear bomb set to go off in New York City within twenty-four hours. See Slobogin, supra note 12, at 43-49. Slobogin proposes that even in such a dire situation, in which a civilized society might perhaps allow the limited use of torture, "we would not permit the torture unless the state can show some degree of certainty that the person tortured possesses the desired information." Id. at 48. Even under the threat of nuclear disaster, then, Slobogin guesses that "virtually everyone would require the government to demonstrate some level of suspicion . . . . Id. at 49. The compeiling governmental interest, then, does not vitiate the need for some quantitatively individualized level of suspicion to justify a significant intrusion. Though, as Slobogin acknowledges, many would condemn the use of torture under any and all circumstances, see id. at $47-48$, the principle applied to the hypothetical torture scenario is nonetheless instructive in the context of more accepted kinds of searches that purportedly serve compelling governmental interests that fall short of the threat of nuclear disaster.

312. Justice Douglas took note in dissent of a further double standard applied there to business and farm subsidies on the one hand, and AFDC benefits on the other. See Wyman v. James, 400 U.S. 309, 331-32 (1971) (Douglas, J., dissenting). 
not shown themselves to be especially suspicious or otherwise deserving of such a focus. 313

The implications of the Court's resolution of James extend beyond the disproportionate intrusiveness of a home search unsupported by individualized suspicion and the evident targeting of poor families. The decision in James also seems to disrupt the substantive parental rights announced in cases such as Meyer, ${ }^{314}$ Pierce, ${ }^{315}$ and Yoder, ${ }^{316}$ providing for the rights, respectively, to teach one's children a foreign language, to send one's children to private school, and to home-educate one's children in accordance with one's religion. The decision similarly disrupts other substantive privacy entitlements, such as the right to marry, ${ }^{317}$ to procreate, ${ }^{318}$ and to use contraceptives. ${ }^{319}$ To engage in these activities which the Court has designated as fundamental, people need a spatial haven from government observation and inspection.

A parent rnust make many decisions about how to handle a child's questions, requests, problems, and power struggles as the child grows and evolves from a dependent infant into a rebellious adolescent and, ultimately, into an adult. Conflicts between parent and child are unavoidable and can provide important educational opportunities if resolved with skill and sensitivity. Skillful resolution, in turn, requires self-confidence and comfort on the part of the parent, along with a perceived ability to be creative and spontaneous in unexpected or difficult circumstances. In times of conflict, a child who knows that a third party sent by the government monitors his parent's disciplinary moves might exploit the power ambiguity that this situation creates. The child might, for example, misbehave or otherwise provoke the parent and then overreact to any discipline in the hopes of forming an alliance with the third-party authority figure. The child might view the social worker's visiting his mother's

313. See Colb, Innocence, supra note 9 , at $1486-87$. It is true that poverty is not a suspect classification for purposes of Equal Protection analysis (or even for purposes of federal anti-discrimination law). In the context of the struggle against very specific types of discrimination, the targeting evident in James therefore does not qualify as being of the most legally objectionable sort. The targeting harm is nonetheless an example of prejudice. As James Jacobs and Kimberly Potter point out in a comprehensive analysis of so-called "hate crime" legislation, "[a]t some level of abstraction all crime, or at least a great deal of it, could be said to be motivated by manifest or latent prejudice-against victims because they are tall, short, rich, poor, good-looking, bad-looking, cocky, vulnerable, sinart, (lumb, members of one gang or another, and so forth. In contemporary American society, however, certain prejudices are officially disfavored-especially those based on race and religion.” James B. Jacobs \& Kimberly A. Potter, Hate Crimes: A Critical Perspective, in 22 Irime \& Just. 1, 3 (Michael Tonry ed., 1997).

314. Meyer v. Nebraska, 262 U.S. 390, 403 (1923).

315. Pierce v. Society of Sisters, 268 U.S. 510, 530, 534-36 (1925).

316. Wisconsin v. Yoder, 406 U.S. 205, 234-36 (1972).

317. See Zablocki v. Redhail, 434 U.S. 374, 388 (1978).

318. See Skinner v. Oklahoma ex rel. Williamson, 316 U.S. 535, 541 (1942).

319. See Eisersstadt v. Baird, 405 U.S. 438, 453-54 (1972); Griswold v. Connecticut, 381 U.S. 479 (1965). 
home as an opportunity to manipulate his mother into giving him what she has previously denied him. ${ }^{320}$ Because the social worker does not participate in rearing the child, he might be unable to gauge when it is or is not appropriate to interfere with what the mother has chosen to do. As the mother's judge, rather than her colleague, his very presence is likely to undermine the mother's authority in her home. ${ }^{321}$

In addition to generating conflict in households already subject to the stresses of poverty, the presence of a social worker in the home and a mother's knowledge that a child could be asked to "inform" on her, could chill the exercise of the mother's right to parent her child in her own, unique way. ${ }^{322}$ As with other fundamental rights, government actions that could chill the exercise of parental rights ought to be constitutionally suspect. ${ }^{323}$ A parent should not lightly

320. Cf. Benjamin Spock, Raising Children in a Difficult Time 130-36 (1974) (explaining that it is natural for a child to try to control his parents through manipulation).

321. Although social workers often intend to treat the family client as a unit, see, e.g., Louise C. Johnson, Social Work Practice: A Generalist Approach 188-89 (4th ed. 1992), the law and their mission as child protection workers compel thein to give inore weight to the claims of children when child abuse is suspected. See Frank D. Fincham et al., The Professional Response to Child Sexual Abuse: Whose Interests Are Served?, 43 Family Relations 244, 249 (1994) (discussing the pressure on social workers to ferret out child abuse); see also Douglas J. Besharov, The Vulnerable Social Worker 85 (1985) (recommending that social workers interview children in private when child abuse is suspected (citing Umited States Center on Child Abuse and Neglect, Dep't of Health, Education and Welfare, We Can Help: A Curriculum on Child Abuse and Neglect: Resource Materials 71 (1979))); Frederic G. Reamer, Social Work Malpractice and Liability 102-IO (1994) (discussing the heightened legal liability and malpractice risks of social workers engaged in protective services).

322. See Jane Ribbens, Mothers and Their Children: A Feminist Sociology of Cliildrearing 198-204 (1994) (arguing that an integral part of a child's socialization is his or her inother's acting as a "mediator" between the child and the outside world).

323. See Cox v. Louisiana, 379 U.S. 536, 557-58 (1965):

[i]t is clearly unconstitutional to enable a public official to determine which expressions of view will be permitted and which will not or to engage in invidious discrimination among persons or groups either by use of a statute providing a system of broad discretionary licensing power or ... the equivalent of such a system by selective enforcement of an extremely broad prohibitory statute.

See also City of Lakewood v. Plam Dealer Publ'g Co., 486 U.S. 750, 771-72 (1988) (holding unconstitutional on its face a local ordinance that granted the mayor authority to approve or deny applications for placing newsracks on public property); Broadrick v. Oklahoma, 413 U.S. 601, 630 (1973) (Brennan, J., dissenting) (discussing how the Court "expressly recognize[s] that overbreadth review is a necessary ineans of preventing a 'chilling effect' on protected expression").

For application of chilling-effect overbreadth protection beyond the First Amendment area, see Planned Parenthood v. Casey, 505 U.S. 833, 893 (1992) (enumerating the sorts of reasons that would motivate women "not wishing to inform their husbands of their decision to obtain an abortion," including "justifiable fears of physical abuse," "a reasonable fear that notifying their husbands will provoke further instances of child abuse," fear of "devastating forms of psychological abuse froin their husbands, including verbal harassment, threats of future violence, the destruction of possessions, physical confinement to the home, the withdrawal of financial support, or the disclosure of the 
be subjected to a regime in which Big Brother (or Big Sister) is watching. ${ }^{324}$

A 1970 article presents an insightful analysis of the connection I have proposed betwe:en Fourth Amendment privacy and the substantive due process right to raise one's children. ${ }^{325}$ The article was published after the Court had noted probable jurisdiction in Wyman v. James, but before it had handed down its decision. The author, Douglas Wickham, criticized the lower court's reasoning deciding the case in favor of Mrs. James. ${ }^{326}$ Wickham contended that the lower court's conclusion that the caseworker in James should have obtained a search warrant prior to any proposed search would do nothing to protect Mrs. James's privacy. Absent a requirement of individualized suspicion, a warrant requirement would introduce a procedural step that would neither prevent nor justify the arbitrary targeting of welfare-dependent families for suspicionless searches. Wickham proposed that, accordingly, a purely formal Fourth Amendment device would not save the constitutionality of the challenged policy. ${ }^{327}$

Although Wickham appealed to constitutional provisions other than the Fourth Amendment in his attempt to bar caseworkers from routine home visits of wrelfare recipients, his argument was on all fours with my

abortion to family and friends," leading the Court to conclude that "[t]he spousal notification requirement is thus likely to prevent a significant number of women from obtaining an abortion"); Michael C. Dorf, Facial Challenges to State and Federal Statutes, 46 Stan. L. Rev. 235, 268-71 (1994) (arguing that the logic of overbreadth analysis should apply equally to furdamental rights outside the context of the First Amendment).

324. In Orwell's Oceania, the government regulated the relationship between parent and child:

The family could not actually be abolished, and, indeed, people were encouraged to be fond of their children in almost the old-fashioned way. The children, on the other hand, were systematically turned against their parents and taught to spy on them and report their deviations. The family had become in effect an extension of the Thought Police.

George Orwell, Nimeteen Eighty-Four 134 (Harcourt Brace Jovanovich ed., I984) (1949).

In recognizing how essential home privacy is to the exercise of parental rights, it would follow not only that individualized suspicion ought to be a necessary precondition to any governmental home "visits," but that only an individualized suspicion concerning a serious offense (including such things as child abuse or neglect) ought to authorize such an intrusion. As discussed in the context of vehicular stops and home searches for evidence of obscene materials, the content of the laws being enforced is as critical to privacy as the quantity of evidence that the government has to suspect a particular mdividual.

325. See Douglas Q. Wickham, Restricting Home Visits: Toward Making the Life of the Public Assistance Recipient Less Public, 118 U. Pa. L. Rev. 1 I88 (1970).

326. See James v. Goldberg, 303 F. Supp. 935, 945 (S.D.N.Y. 1969) (three judge panel). Recall that the respondent (Mrs. James) was a welfare recipient who refused to consent to a caseworker's home visit and whose welfare benefits were subsequently terminated. See Wyman v. James, 400 U.S. 309, 313-14 (1971).

327. For a decision approving such a search warrant not based upon any individualized suspicion, see Camara v. Municipal Court of San Francisco, 387 U.S. 523 (1967). 
critique of the Supreme Court's reasoning in Payton, Steagald, and Welsh for the failure to address substantive concerns with substantive measures. ${ }^{328}$ In evaluating the various conditions attached to the provision of welfare benefits, Wickham saw the necessity for a certain amount of unregulated parental authority as part of any successful parent-child relationship. He proposed, for example, that "by conditioning the grant of economic subsistence on the acceptance of social services such as instruction on house keeping, raising children, budgeting the grant, or conducting one's social life, the administrators of public assistance deprive the recipient of control over her existence." 329 He suggested that " $[t] 0$ enjoy privacy, the public assistance recipient ... alone must set the moral tone of her home, and departmental investigations of her case should not unnecessarily disrupt her relationships with her friends and family by broadcasting the facts of her economic plight."330 Privacy from observation is an essential prerequisite to the ability to enjoy constitutionally protected relationships, and therefore, "[a]n attempt to expand the scope of Mrs. James' privacy vis-à-vis the public assistance agency might simply refer to Griswold and assert that the case stands for the proposition that the government may not deprive individuals of control over certain aspects of their lives."331

\section{CONCLUSION}

Following the atrocities of World War II, there was an international reassessment of the level of trust that people might safely place in the hands of government officials. ${ }^{332}$ Within the United States, this reassess-

328. See supra Part II.B.

329. Wickham, supra note 325 , at 1194.

330. Id. at 1195.

331., Id. at 1204.

332. Justice Jackson, who was a prosecutor at Nuremberg, contrasted the American system of government with autocratic systems in West Virginia State Board of Education $v$. Barnette.

Governunent of limited power need not be anemic government. Assurance that rights are secure tends to diminish fear and jealousy of strong government, and by making us feel safe to live under it makes for its better support. Without promise of a limiting Bill of Rights it is doubtful if our Constitution could have mustered enough strength to enable its ratification. To enforce those rights today is not to choose weak government over strong government. It is only to adhere as a means of strength to individual freedom of mind in preference to officially disciplined uniformity for which history indicates a disappointing and disastrous end.

319 U.S. 624, 636-37 (1943). The inanifest distrust of autocratic states following World War II is embodied in the Preamble to the Charter of the United Nations, which resolves, in part

to save succeeding generations from the scourge of war, which twice in our lifetime has brought untold sorrow to mankind, and to reaffirm faith in fundamental human rights, in the dignity and worth of the human person, in the equal rights of men and woinen and of nations large and small, and 
ment included the Warren Court's Fourth Amendment jurisprudence of privacy, consisting of a right to avoid "the knock at the door" in the middle of the night that seemed to capture an image of fascism in which searches and seizures are left largely unregulated. ${ }^{333}$ This doctrine of Fourth Amendment privacy has evolved largely independently of a separate, simultaneous set of developments in the law of substantive due process privacy. T'hough the same judicial body, the highest court of the United States, elaborated the two classes of privacy rights, this Court failed to connect the procedural with the substantive and therefore failed to provide an integrated and meaningful construction of "privacy" that would appear coherent to readers of judicial opinions. ${ }^{334}$

The preceding pages have explained the nature of the procedure/ substance divide and have provided examples of cases in which the Court has inched toward a more integrated doctrine of privacy. I have proposed, on the basis of insights contained in such cases, that the Court could construct a Fourth Amendment doctrine that consciously and consistently inquires into the substantive and procedural features of challenged governmental activity. Such an inquiry would involve the balancing of intrusions against objectives-a balancing that would supplement the bare, quantitative tests that courts currently apply in most cases. The balancing inquiry would take into account the incremental impact of the automatic search-and-seizure authority that currently accompanies all criminal legislative enactments. The Supreme Court could accordingly begin to employ an analysis that would probe the seriousness of criminal acts the discovery of which might require intrusions that are either disproportionate in relation to the loss of spatial privacy or unduly destruc-

to establish conditions under which justice and respect for the obligations arising from treaties and other sources of international law can be maintained, and to promote social progress and better standards of life in larger freedom .... .

Two framers of the Charter construe the phrase "in larger freedom" to "suggest[ ] a conception of freedom akin to that developed in President Roosevelt's annual message to Congress of January 6, 1941 in which he listed 'four essential human freedoms." Leland M. Goodrich \& Edrard Hambro, Charter of the United Nations 91 (2d ed. 1949). These comprise "freedom of speech and expression [,]' .. 'freedom of every person to worship God in his own way[,]' . . 'freedom from want[,]' . . . and 'freedom from fear'." ld. (quoting Franklin Delano Roosevelt, Annual Message of the President to Congress, in Documents on American Foreign Relations III, 1940-1941, at 33 (S. Sliepard Jones \& Denys P. Myers eds., 1941)). These freedoms are routinely denied by autocratic regimes.

333. See Gooding v. United States, 416 U.S. 430, 462 (1974) (Marshall, J., dissenting) (arguing that " $[t]$ he: idea of the police unnecessarily forcing their way into the home in the middle of the night-frequently, in narcotics cases, without knocking and announcing their purpose-rousing the residents out of their beds, and forcing them to stand by in indignity in their night clothes while the police rummage througl their belongings does indeed smack of a "police state" lacking in the respect for ... the riglit of privacy dictated by the U.S. Constitution." (quoting S. Rep. No. 91-538, at 12 (I969)) (ellipsis in original)).

334. See, e.g., Bork, supra note 113 , at $95-100$ (criticizing the right to privacy as a "constitutional time: bomb"); Ely, supra note 113, at 15 (arguing that the Due Process Clause of the Fourteenth Amendment sbould only ensure procedural fairness). 
tive of the exercise of fundamental rights that require such spatial privacy. Through such reform of privacy law, the Court can put to rest the suggestion that the "privacy" of substantive constitutional law and the "privacy" of criminal procedure share only a name. 